GEAP-5616

AEC RESEARCH AND

DEVELOPMENT REPORT

APRIL 1968

\title{
NINE-ROD CRITICAL HEAT FLUX INVESTIGATION, STEAM-WATER AT 600 TO 1400 psia FINAL SUMMARY REPORT
}

E. JANSSEN

U.S. ATOMIC ENERGY COMMISSION CONTRACT AT(04-3)-189 PROJECT AGREEMENT 44 


\section{DISCLAIMER}

This report was prepared as an account of work sponsored by an agency of the United States Government. Neither the United States Government nor any agency Thereof, nor any of their employees, makes any warranty, express or implied, or assumes any legal liability or responsibility for the accuracy, completeness, or usefulness of any information, apparatus, product, or process disclosed, or represents that its use would not infringe privately owned rights. Reference herein to any specific commercial product, process, or service by trade name, trademark, manufacturer, or otherwise does not necessarily constitute or imply its endorsement, recommendation, or favoring by the United States Government or any agency thereof. The views and opinions of authors expressed herein do not necessarily state or reflect those of the United States Government or any agency thereof. 


\section{DISCLAIMER}

Portions of this document may be illegible in electronic image products. Images are produced from the best available original document. 
NINE-ROD CRITICAL HEAT FLUX

INVESTIGATION, STEAM-WATER AT 600 TO 1400 psia,

FINAL SUMMARY REPORT

by

E. Janssen

Approved:

\section{LEGAL NOTICE}

This report was prepared as an account of Government sponsor States, nor the Commission, nor any person acting on behalf of the Commission: A. Makes any warranty or representation, expressed or implied, with respect to the accuracy, completeness, or usefulness of the information contained in this report or thet the use of any lnforman, apparatus, method, or process disclosed in this report may not infinge prlvately owned rights; or

B. Assumes any liabllitles with respect to the use of, or for damages resulting from the use of any information, apparatus, method, or process disclosed in this report.

As used in the above, "person acting on behalf of the Commission" Includes any employee or contractor of the Commission, or employee of such contractor, to the extent that Buoh cmployee or conth'aciur of the Commission, or employee of auch contractor prepares, disseminates, or provides access to, any information pursuant to his employment or contrac with the Commission, or his employment with such contractor.

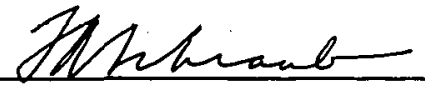

F. A. Schraub, Manager Core Development

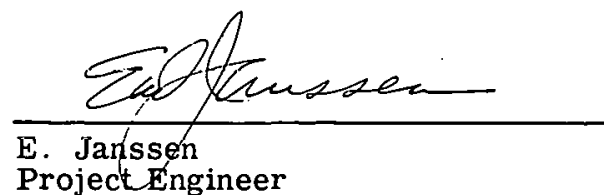

Project Éngineer

U.S. Atomic Énergy Commission

Cuntract AT (04=3) $=189$

Project Agreement 44

Printed in U.S.A. Available from the

Clearing House for Federal Scientific and Tecbnical Information

National Bureau of Standards, U.S. Department of Commerce

Springfield, Virginia

Pricei $\$ 3.00$ per copy 


\section{LEGAL NOTICE}

This report was prepared as an account of Government sponsored work. Neither the United States, nor the Commission, nor any person acting on bebalf of the Commission:

A. Makes any warranty or representation, expressed or implied, with respect to the accuracy, completeness, or usefulness of the information contained in this report, or that the use of any information, apparatus, metbod, or process disclosed in this report may not infringe privately owned rights; or

B. Assumes any liabilities with respect to the use of, or for damages resulting from the use of any information, apparatus, metbod, or process disclosed in this report.

As used in the above, "person acting on bebalf of the Commission" includes any employee or contractor of the Commission, or employee of such contractor, to the extent that such employee or contractor of the Commission, or employee of such contractor prepares, disseminates, or provides access to, any information pursuant to bis employment or contract with the Commission, or bis emplovment with such contractor. 


\section{TABLE OF CONTENTS}

$\begin{array}{lll}\text { SECTION I } & \text { SUMMARY } & \frac{\text { Page }}{-1-} \\ \text { SECTION II } & \text { INTRODUCTION } & -2- \\ \text { SECTION III } & \text { DESCRIPTION OF EQUIPMENT AND TEST PROCEDURE } & -3- \\ & 3.1 \quad \text { First Channel } & -3- \\ & 3.2 \quad \text { New Channel } & -3- \\ \text { SECTION IV } & \text { RESULTS AND DISCUSSION } & -8- \\ & 4.1 \quad \text { Effect of Quality } & -8- \\ & 4.2 \quad \text { Effect of Heated Length } & -8- \\ & 4.3 \quad \text { Effect of Flow Rate } & -21- \\ & 4.4 \quad \text { Effect of Pressure } \\ & 4.5 \quad \text { Effect of Rod-to-Wall Spacing } & -21- \\ \text { SECTION V } & \text { COMPARISON WITH OTHER MULTIROD RESULTS } & -22- \\ \text { SECTION VI } & \text { EVALUATION OF MULTISUBCHANNEL COMPUTER CODES } & -34- \\ \text { SECTION VII } & \text { CONCLUSIONS } & -48- \\ & \text { ACKNOWLEDGMENTS }\end{array}$




\section{LIST OF ILLUSTRATIONS}

Sectional View of First Nine-Rod Assembly with Pressure Vessel

Nine-Rod Critical Heat Flux versus Quality at $1000 \mathrm{psia}, 0.5 \times 10^{6} \mathrm{lb} / \mathrm{h}-\mathrm{ft}^{2}$, Various Ileated Lengths

Nine-Rod Critical Heat Flux versus Quality at $1000 \mathrm{psia}, 0.75 \times 10^{6} \mathrm{lb} / \mathrm{h}-\mathrm{ft}^{2}$, Various Heated Lengths

Nine-Rod Critical Heat Flux versus Quality at $1000 \mathrm{psia}, 1.0 \times 10^{6} \mathrm{lb} / \mathrm{h}-\mathrm{ft}^{2}$, Various Heated Lengths

Nine-Rod Critical Heat Flux versus Quality at $1000 \mathrm{psia}, 1.25 \times 10^{6} \mathrm{lb} / \mathrm{h}-\mathrm{ft}^{2}$, Various Heated Lengths

Nine-Rod Critical Heat Flux versus Quality at $0.5 \times 10^{6} \mathrm{lb} / \mathrm{h}-\mathrm{ft}^{2}$, Various Pressures

Nine-Rod Critical Heat Flux versus Quality at $1.0 \times 10^{6} \mathrm{lb} / \mathrm{h}-\mathrm{ft}^{2}$,

Nine-Rod Critical Hea Two Rod-to-Wall Clearances

Nine-Rod Critical Heat Flux ve Two Rod-to-Wall Clearances

Critical Heat Flux ver
Various Rod Bundles

Critical Heat Flux ve Various Rod Bundles

Critical Heat Flux vers Various Rod Bundles

Critical Heat Flux vers Various Rod Bundles

Critical Heat Flux ver Two Correlations

$$
\begin{aligned}
& \text { sus Quality at } 1000 \text { psia, } 0.5 \times 10^{6} \mathrm{lb} / \mathrm{h}-\mathrm{ft}^{2} \text {, } \\
& \text { sus Quality at } 1000 \mathrm{psia}, 0.75 \times 10^{6} \mathrm{lb} / \mathrm{h}-\mathrm{ft}^{2} \text {, }
\end{aligned}
$$$$
\text { rsus Quality at } 1000 \mathrm{psia}, 1.0 \times 10^{6} \mathrm{lb} / \mathrm{h}-\mathrm{ft}^{2} \text {, }
$$

Critical Heat Flux versus Quality at $1000 \mathrm{psia}, 0.75 \times 10^{6} \mathrm{lb} / \mathrm{h}-\mathrm{ft}^{2}$, Two Correlations

Critical Heat Flux versus Quality at $1000 \mathrm{psia}, 1.0 \times 10^{6} \mathrm{lb} / \mathrm{h}-\mathrm{ft}^{2}$, Two Correlations

Critical Heat Flux Two Correlations

Division of Nine-Rod Channel into Subchannels, and Subchannel Numbering Scheme

Pertinent Channel Dimensions for Multisubchannel Computer Code

Critical Heat Flux versus Quality Calculated by COBRA for Subchannel No. 1, at $1000 \mathrm{psia}, 0.5 \times 10^{6} \mathrm{lb} / \mathrm{h}-\mathrm{ft}^{2}$

Critical Heat Flux versus Quality Calculated by COBRA for Subchannel No. 1, at $1000 \mathrm{psia}, 1.0 \times 106 \mathrm{lb} / \mathrm{h}-\mathrm{ft}^{2}$

Critical Heat Flux versus Quality Calculated by HAMBO for Subchannel No. 1, at $1000 \mathrm{psia}, 0.5 \times 106 \mathrm{lb} / \mathrm{h}-\mathrm{ft}^{2}$

Critical Heat Flux versus Quality Calculated by HAMBO for Subchannel No. 1, at $1000 \mathrm{psia}, 1.0 \times 10^{6} \mathrm{lb} / \mathrm{h}-\mathrm{ft}^{2}$ 
1A Critical Heat Flux Conditions First Nine-Rod Test Channel 0.4375-Inch-Diameter Rods

$-9-$

1B Critical Heat Flux Conditions New Nine-Rnd Test Channel 0.570-Inch-Diam eter Rods

Subchannel Exit Conditions Calculated with COBRA Code Using Available Two-Phase Multiplier

5 Subchannel Exit Conditions Calculated with HAMBO Code Using Two-Phase Multiplier $\phi=1+34 \times$ 


\section{SECTION I}

\section{SUMMARY}

Critical heat flux (CHF) data were obtained in two "clean"* nine-rod test channels. The rods were arranged in a square array. The rod-to-wall clearance was 0.135 inch, except for a few runs at $0.060 \mathrm{inch}$; the rod-to-rod clearance was 0.187 inch or 0.183 inch. The heated length varied from 30 inches to 72 inches. The heat flux was uniform in the axial direction. Data were obtained both with all rods uniformly heated and with one of the corner rods slightly (on the order of $10 \%$ ) higher than the average. The flow was varied from $0.3 \times 10^{6}$ to $1.25 \times 10^{6} \mathrm{lb} / \mathrm{h}-\mathrm{ft}^{2}$, and the pressure was varied from 600 to 1400 psia. On the basis of the test results it is concluded that:

1. For rods in a normally-spaced square array, the CHF occurs on one of the corner rods.

2. The CHF decreases as the average quality increases, other things being the same. The average quality is the dominant parameter in determining $\mathrm{CHF}$.

3. There is no strong or consistent effect of length on CHF.

4. There is no flow effect on CHF for flows greater than $0.75 \times 10^{6} \mathrm{lb} / \mathrm{h}-\mathrm{ft}^{2}$. For flows less than this, the CHF tends to vary in an inverse manner with the flow, but the effect is not strong.

* "Clean" refers to the fact that the means for maintaining the rods in correct relative alignment were designed to produce as little disturbance as possible to the flow.
5. In the range of pressures from 600 to 1400 psia, the CHF varies in an inverse manner with the pressure, other things being the same.

6. A reduction in rod-to-wall clearance from 0.135 inch to 0.060 inch causes a $15 \%$ reduction on $\mathrm{CHF}$.

A comparison of the nine-rod (square array) CHF data reported here with 19-rod, 37-rod, and seven-rod (circular array) CHF data reported elsewhere, shows poor agreement when the comparison is on the basis of the same average exit quality and mass velocity. A comparison, on the same basis, of the nine-rod CHF data with multirod correlations of Becker and Barnett shows similar poor agreement. These two correlations are based largely on results obtained with circular arrays. It is evident that the use of average channel conditions for correlating purposes has significant limitations, in particular for correlating circular-array results with square-array results.

Multisubchannel computer codes consider channel conditions in more detail, thus providing the means for a possible improvement in the correlation of multirod CHF data. Two such codes were investigated, the COBRA (Batelle Northwest) and the HAMBO (U.K. Atomic Energy Establishment, Winfrith). Each of these, in combination with a simple channel (internally-heated annulus) CHF correlation, was used to predict $\mathrm{CHF}$ in the nine-rod channel. Fair to good agreement was obtained between predicted and measured CHF. The use of such codes appears to be a promising procedure for predicting CHF in a multirod array. 


\section{SECTION II}

\section{INTRODUCTION}

Many important systems involve twophase flow and boiling heat transfer. Notable among these are water cooled nuclear power reactors. The nuclear fuel is in the form of metal-clad rods, arranged in evenly-spaced arrays, or bundles. The coolant enters at one end of the bundle as a liquid, and flows parallel to the rods in the spaces between them. When the reactor is operating near rated conditions, very high rates of heat transfer take place. It is important to be able to predict, under conditions where boiling occurs, what the limit of heat transfer is in such a complex channel. We here refer to the limit commonly known as the critical heat flux, but also known as the boiling crisis, departure from nucleate boiling, burnout, or dryout.

A thorough study of this problem (the prediction of CHF in multirod channels) can follow two paths. The first is to make a detailed investigation of how the liquid and vapor phases distribute themselves, i.e., the flow structure, and then to combine this with knowledge of CHF generated in investigaliuns with simpler channels, to predict the CHF in multirod channels. The second is to measure directly the CHF in a variety of multirod channels. In fact, both approaches to the problem are necessary.

The Atomic Power Equipment Department of the General Elcctric Company entered into a contract with the U.S. Atomic Energy Commission in October 1964, to investigate two-phase flow and heat transfer in multirod geometries using the two approaches mentioned in the preceding paragraph. Task A of this program was concerned with flow structure investigations and Task $\mathrm{B}$ with direct measurement of multirod CHF. The scope for Task B also included the evaluation of one or two multisubchannel hydraulic model computer codes now in existence which predict the two-phase flow distribution in a complex channel. This, in combination with a simple channel CHF correlation, can be used to predict multirod $\mathrm{CHF}$.

This report is the final report on the work carried out under Task $B$.

The objectives for the work of Task B were as follows:

a. Measure the critical heat flux for a "clean" vertical nine-rod ( 3 by 3 square array) geometry with uniform heat flux, under forced convection conditions, with water at a high pressure (600 to $1400 \mathrm{psia}$ ), and flow upward.

b. Investigate the effect of certain parameters, specifically quality, flow rate, heated length, pressure, and rod-to-wall spacing.

c. Use the results to evaluate one or more computer models as a basis for CHF prediction.

The report of the work follows. 


\section{DESCRIPTION OF EQUIPMENT AND TEST PROCEDURE}

Two nine-rod test channels were used for the work reported here.

\subsection{First Channel}

The first nine-rod test channel (hereinafter referred to as the first channel) has been described in detail elesewhere. (1) The salient geometrical features are:

$\begin{array}{lc}\begin{array}{l}\text { Number of rods } \\ \text { Rod Diameter }\end{array} & \text { Nine (3 by } 3 \text { square array) } \\ \begin{array}{l}\text { Radius of Channel } \\ \text { Corner }\end{array} & 0.4375 \text { inch } \\ \text { Rod-to-Rod Clearance } & 0.354 \text { inch } \\ \text { Rod-to-Wall Clearance } & 0.187 \text { inch } \\ \text { Hydraulic Diameter } & 0.485 \text { inch } \\ \text { Heated Length } & 30 \text { and } 60 \text { inches } \\ \text { Entrance Calming } & 10 \text { inches }\end{array}$

Each of the nine rods has uniform axial heat flux. Most of the data. were obtained with the heat flux on one of the corner rods abuut $10 \%$ * higher than the average for the remaining eight rods. The heat flux for these remaining eight was within $5 \%$ of uniform.

A sectional view of the first nine-rod channel installed in its pressure vessel is shown in Figure 1. The rods are constructed of Inconel-X tubes. Electrical heating of the tubes simulates internal heat generation in reactor fuel rods. Subcooled water enters the channel at the bottom. The flow leaves the top of the channel as a saturated steamwater mixture. Rod-to-rod and rod-to-wall spacing is maintained by means of $1 / 8$-inchdiameter pins plus slender spool-type pins.

* Actually the heat flux varied from $3 \%$ to $14 \%$ above the average, depending upon the particular set of rods.
The last set of $1 / 8$-inch pins is located 14.5 inches before the exit end of the heated length. A set of spool-type pins (rod-wall only) is located 6 inches before the end of the heated length.

The first channel was installed in the Heat Transfer Facility loop as it existed prior to July 1967. That loop (together with associated instrumentation) is described in detail in Reference (2).

The CHF was detected by means of thermocouples located near the exit end of the "hot" corner rod mentioned above. The CHF point was approached by holding pressure, flow, and subcooling constant, and gradually increasing the power (in steps of 1 to $2 \%$ ), until one or more thermocouples indicated a $\mathrm{CHF}$ condition.

\subsection{New Channel}

The second nine-rod test channel (hereinafter referred to as the new channel) was designed around a new type of electricallyheated rod developed by G.E. for this particular application. The rod is clad with a nickel tube insulated from the electrical heater element so that the exterior of the rod may be at ground potential, thereby eliminating any shorting problems. The ends of five individual chromel wires are fusion welded to the inside of the nickel tube close to the exit end of the heated length to form chromelnickel thermocouple junctions. These are utilized in CHF detection.

The salient geometrical features of the new channel are:

Number of Rods Nine ( 3 by 3 square array) Rod Diameter $\quad 0.570$ inch 
Radius of Channel Corner

Rod-to-Rod Clearance

0.375 inch

Rod-to-Wall Clearance

0.183 inch

Hydraulic Diameter

0.135 inch

Heated Length

0.497 inch

Calming Length 5 -inch converging area plus 3.5-inch constant area

The cross-sectional dimensions of the channel can be altered by inserting a $0,070-$ inch liner, which effectively reduces the channel inside dimension by 0.150 inch, thus reducing the channel corner radius to $0.364 \mathrm{inch}$, the rod-to-wall clearance to 0.060 inch, and the hydraulic diameter to 0.397 inch. Other dimensions remain as listed above.

Each of the nine rods has uniform axial heat flux. Moreover, the heat flux is uniform in the transverse direction, within $2 \%$, based on resistance measurements at room temperature.

A sectional view of the new nine-rod channel is shown in Figure 2. The provision for maintaining rod spacing is similar to that for the first channel, except that no spooltype pins are used. Note also that the first support past the end of the heated length is a tie plate located 19-5/8 inches above the last set of pins.

'I'he new channel was installed in the Heat Transfer Facility loop as modified after September 1967, shown schematically in Figure 3. This facility now consists of a single main loop of 3-inch Schedule-80 stainless steel pipe; two steam drums connected in parallel; steam condenser (in secondary loop off of steam drum); downcomer; turbinetype flowmeter; subcooler, subcooler pump, and remote-operated valve (in secondary loop just ahead of pumps); two canned-rotor pumps in series; flow control valve with remoteoperated trimmer valve in parallel with it; nrifice-type flowmeter at end of straight horizontal run; and test section and riser. Pressure is controlled by regulating the rate at which cooling air blows over the steam con. denser. This is accomplished automatically by louvers controlled by a pressureresponsive servo.

With the exception of the provisions for redundant flow measurement and remote control of subcooling and primary flow, these are features which the loop had before modification. However, there are certain features which the loop did not have before modification, namely: a.) internal provision for flow calibration against a volumetric standard; thus permitting calibration with high temperature water; b.) improved provision for venting the loop of air during warmup; and c.) larger blowdown line, elimination of dead ends, and generally better provision for cleaning the loop and keeping it clean, thus enhancing the water purity.

In addition to the modification made directly to the loop, the instrumentation for measurement and control of loop conditions was modified, to increase the rate and accuracy of data acquisition. The addition of a turbine-type flowmeter has already been mentioned. A Hewlett-Packard DYMEC data acquisition system now prints out the millivolts corresponding to all the significant parameters, i.e., the flow (turbine flowmeter), the inlet subcooling (differential thermocouples between inlet and test section exit), the pressure, the power (new SCI wattmeter), and also the temperature at the turbine meter (chromel-alumel thermocouples with $150^{\circ} \mathrm{F}$ cold junction temperature). A considerable saving in time is realized in both reduced time to set conditions and reduced time to record data. The estimated accuracies of the various quantities, when properly zeroed and calibrated, are:

\begin{tabular}{|c|c|c|}
\hline Quantity & Instrument & $\begin{array}{l}\text { Estimated } \\
\text { Accuracy }\end{array}$ \\
\hline Pressure & $\begin{array}{l}\text { Statham Strain Gage } \\
\text { Transducer }\end{array}$ & 3 psi \\
\hline Flow & Potter Turbine Meter & $1.5 \%$ \\
\hline $\begin{array}{l}\text { Inlet } \\
\text { Subcooling }\end{array}$ & $\begin{array}{l}\text { Conax-Bheathed } \\
\text { Chromel-Alumel } \\
\text { Thermocouples }\end{array}$ & $4 \mathrm{Blu} / 1 \mathrm{~b}$ \\
\hline Pọwer & SCI Wattmeter & $1 \%$ \\
\hline
\end{tabular}




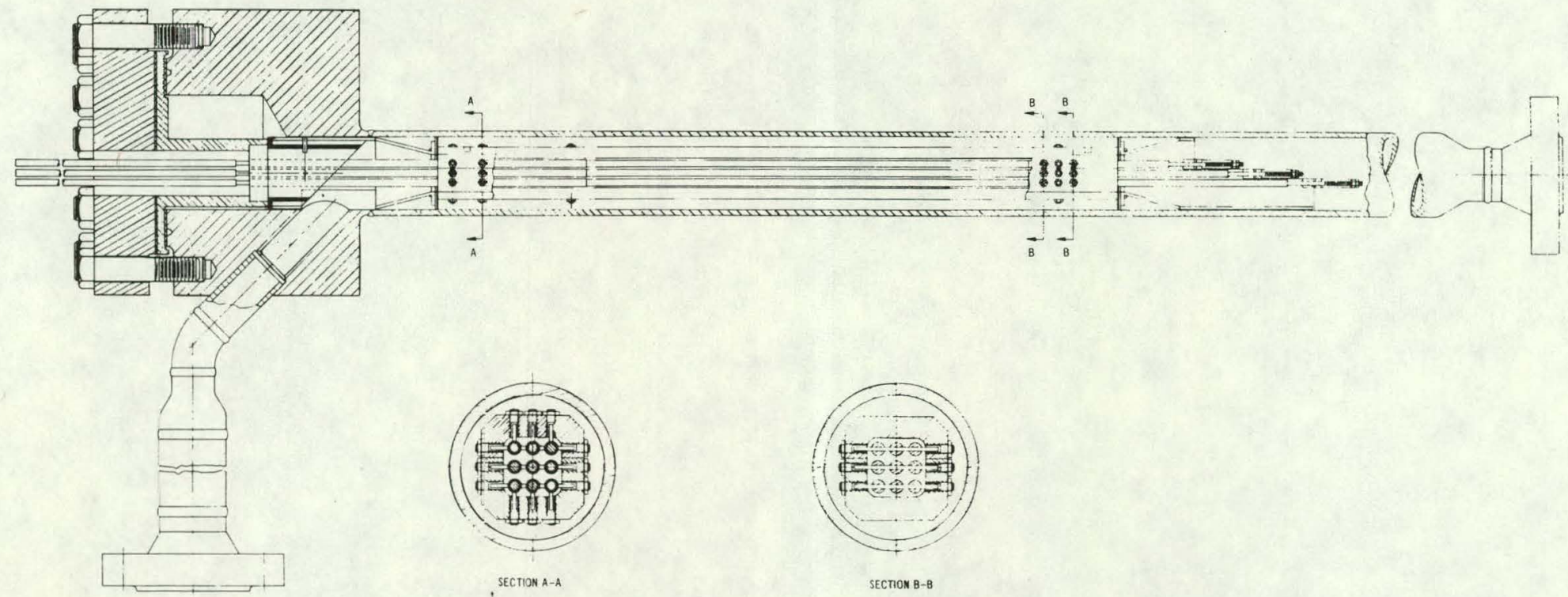




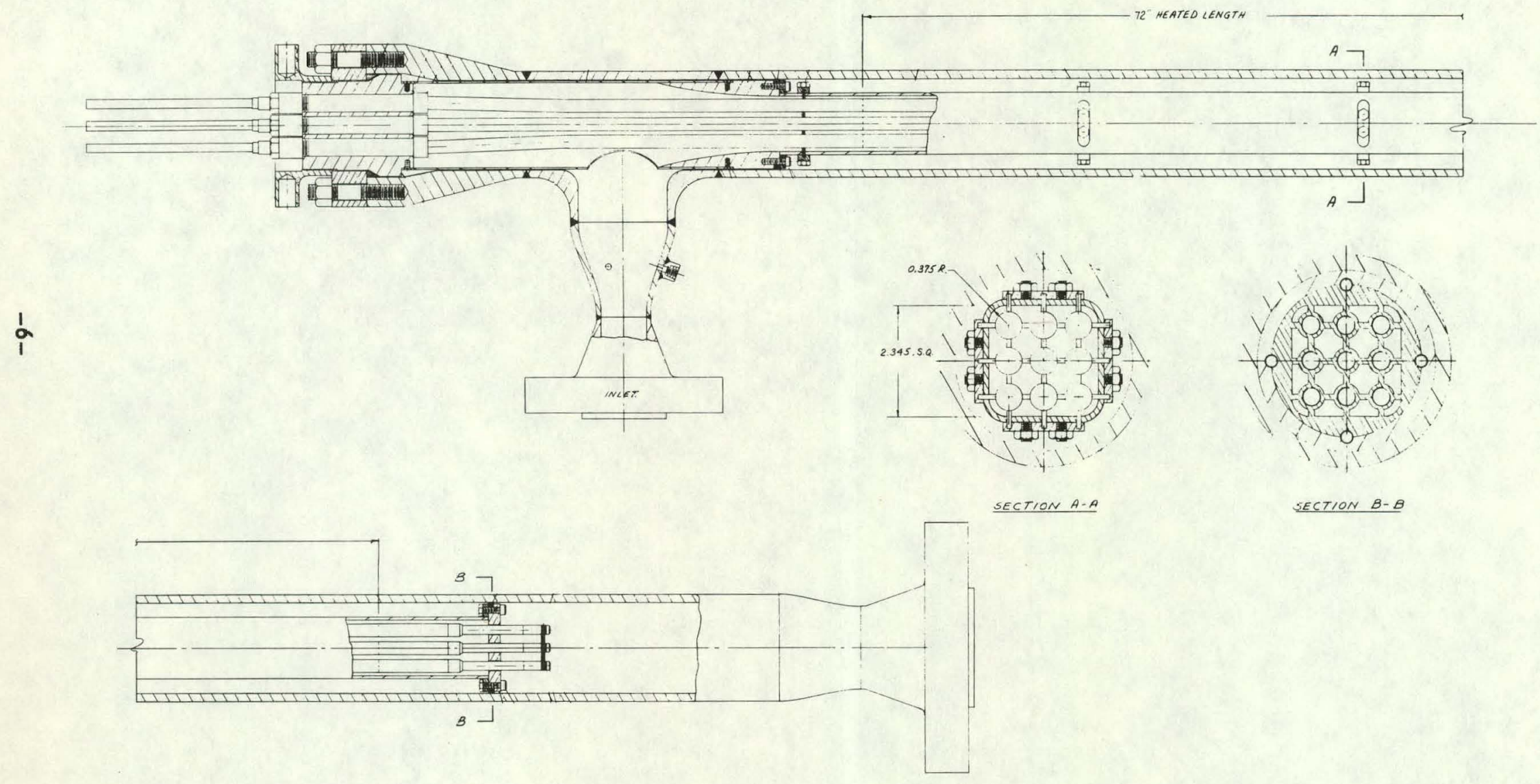

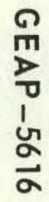

FIGURE 2. SECTIONAL VIEW OF NEW NINE-ROD ASSEMBLY WITH PRESSURE VESSEL 


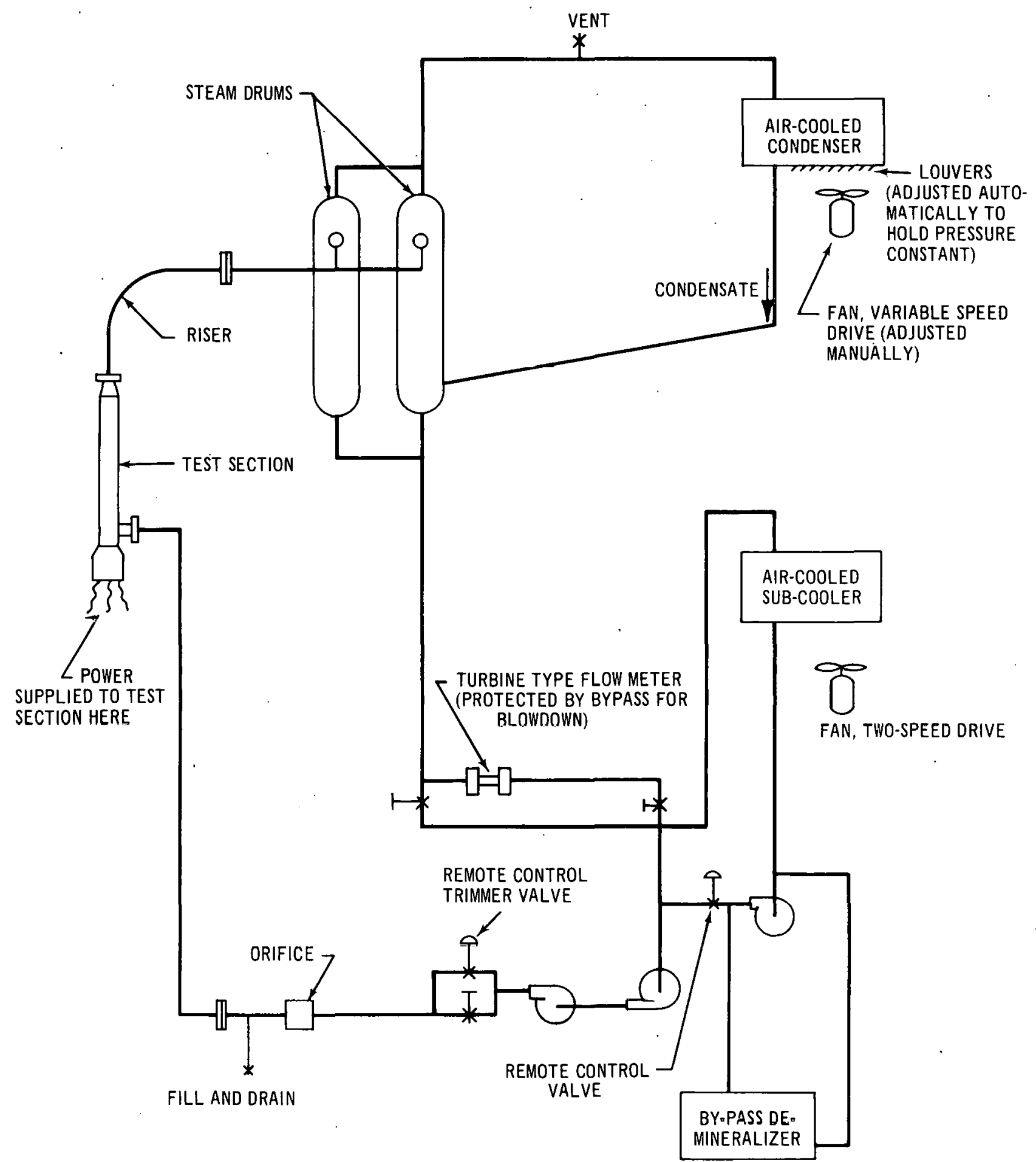

FIGURE 3. SCHFMATIC. OF HEAT TRANSFER FACILITY LUUP AFTER SEPTEMBER 1967 
The CHF continues to be detected by thermocouples located near the exit end of the rods most likely to experience it. There are 16 Sanborn channels for thermocouple signal tracesenough to monitor all nine rods if necessary.

The procedure in approaching a CHF point is essentially the same as be- fore. Immediately following the occurrence of a CHF, the power is dropped to zero, then brought back on at a lower level, so that normal boiling heat transfer is re-established. The subcooling is then changed and the process is repeated to get a $\mathrm{CHF}$ point at a slightly different condition.

\section{SECTION IV}

\section{RESULTS AND DISCUSSION}

The measured values of CHF for various pressures, flows, and qualities are listed in Tables $1 \mathrm{~A}$ and $1 \mathrm{~B}$ (first test channel and new test channel, respectively). The listed values for both the mass velocity and the exit quality are average values for the channel as a whole. The listed value for the heat flux is the average for all nine rods when they are intended to be uniform, but is the value for the "hot" corner rod where this one rod is intentionally about $10 \%$ higher in heat flux than the others. The results are presented graphically in Figures 4 through 12 .

Twelve of the runs with the first test channel were made using uniform rods; i.e., the heat flux was uniform across the rods as well as axially. The remainder of the runs with the first test channel were made using one corner rod which had a slightly $(\sim 10 \%)$ higher heat flux then the other rods. The CHF invariably occurred on one of the corner rods, on the side of the rod facing the channel corner, whether all the rods were uniform or one corner rod was $10 \%$ higher in heat flux. (It always occurred on the "hot" rod when one was used.) When the CHF on the "hot" corner rod is plotted versus average exit quality, it cannot be distinguished from the CHF of the uniform rods versus average exit quality [see Reference (1)]. In the ensuing discussion of test results, no differentiation will be made between "uniform rods" and "hot rod" data.
All the runs with the new test channel were made using uniform rods.

\subsection{Effect of Quality}

The CHF invariably occurred at the exit end, which is to be expected with uniform axial heat flux. Thus the average quality for the channel at the position of CHF is identically the average exit quality. It is shown by the data (see Figures 4 through 12) that the CHF decreases as the average quality increases, other things being the same. Even though other parameters do have an effect on CHF, as will be noted below, the average quality is the dominant parameter. Thus, at a flow of $0.5 \times 10^{6} \mathrm{lb} / \mathrm{h}-\mathrm{ft}^{2}$ and a pressure of $1000 \mathrm{psia}$, an increase in quality from $20 \%$ to $50 \%$ brings about a $50 \%$ reduction in CHF.

\subsection{Effect of Heated Length}

A comparison (refer to Figures 4 through 7) between data taken with a 30 -inch heated length and data taken with a 60-inch heated length suggests that: a.) the CHF is higher with the shorter heated length, and b.) the improvement in CHF of the shorter over the longer length is greatest at the highest flow $\left(1.25 \times 10^{6} \mathrm{lb} / \mathrm{h}-\mathrm{ft}^{2}\right)$, but is so small as to be practically nonexistent at the lowest flow $\left(0.5 \times 10^{6} \mathrm{lb} / \mathrm{h}-\mathrm{ft}^{2}\right)$. 
TABLE 1A

CRITICAL HEAT FLUX CONDITIONS

FIRST NINE-ROD TEST CHANNEL 0.4375-INCH-DIAMETER RODS

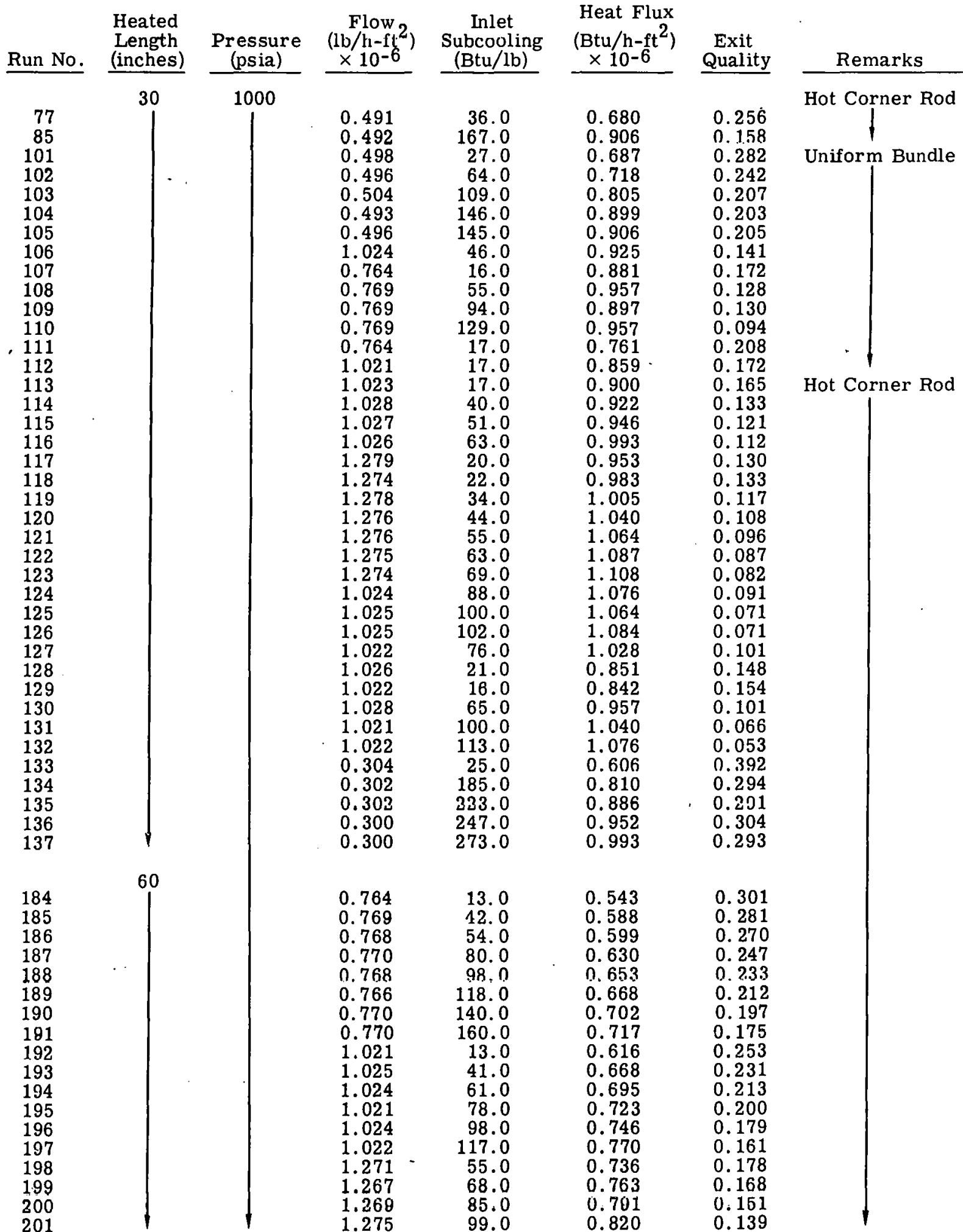


TABLE 1A (Continued)

\begin{tabular}{|c|c|c|c|c|c|c|c|}
\hline Run No. & $\begin{array}{l}\text { Heated } \\
\text { Length } \\
\text { (inches) } \\
\end{array}$ & $\begin{array}{c}\text { Pressure } \\
\text { (psia) }\end{array}$ & $\begin{array}{c}\text { Flow } \\
\left(\mathrm{lb} / \mathrm{h}-\mathrm{ft}^{2}\right) \\
\times 10^{-6} \\
\end{array}$ & $\begin{array}{c}\text { Inlet } \\
\text { Subcooling } \\
(\mathrm{Btu} / \mathrm{lb}) \\
\end{array}$ & $\begin{array}{c}\text { Heat Flux } \\
\left(\text { Btu/h-ft }{ }^{2}\right) \\
\times 10^{-6} \\
\end{array}$ & $\begin{array}{c}\text { Exit } \\
\text { Quality } \\
\end{array}$ & Remarks \\
\hline $\begin{array}{l}202 \\
203 \\
204 \\
205 \\
206 \\
207 \\
208 \\
209 \\
210 \\
211 \\
212 \\
213 \\
214 \\
215 \\
216 \\
217 \\
218 \\
219 \\
220 \\
221\end{array}$ & 60 & $\left.\right|^{1000}$ & $\begin{array}{l}0.491 \\
0.491 \\
0.488 \\
0.491 \\
0.492 \\
0.492 \\
0.491 \\
0.497 \\
0.495 \\
0.491 \\
0.492 \\
0.496 \\
0.491 \\
0.491 \\
0.491 \\
0.492 \\
0.492 \\
0.491 \\
0.492 \\
0.492\end{array}$ & $\begin{array}{r}16.0 \\
24.0 \\
33.0 \\
46.0 \\
53.0 \\
62.0 \\
79.0 \\
18.0 \\
102.0 \\
108.0 \\
118.0 \\
130.0 \\
140.0 \\
149.0 \\
159.0 \\
167.0 \\
178.0 \\
190.0 \\
201.0 \\
210.0\end{array}$ & $\begin{array}{l}0.475 \\
0.478 \\
0.488 \\
0.497 \\
0.512 \\
0.520 \\
0.526 \\
0.490 \\
0.553 \\
0.555 \\
0.565 \\
0.569 \\
0.580 \\
0.588 \\
0.613 \\
0.622 \\
0.639 \\
0.637 \\
0.640 \\
0.645\end{array}$ & $\begin{array}{l}0.412 \\
0.404 \\
0.400 \\
0.387 \\
0.388 \\
0.382 \\
0.362 \\
0.418 \\
0.348 \\
0.345 \\
0.337 \\
0.318 \\
0.319 \\
0.312 \\
0.320 \\
0.314 \\
0.313 \\
0.293 \\
0.278 \\
0.269\end{array}$ & \multirow[t]{3}{*}{ Hot Corner Rod } \\
\hline 269 & 30 & & 1.019 & 135.0 & 1.148 & 0.056 & \\
\hline $\begin{array}{l}419 \\
422 \\
434 \\
435 \\
436 \\
437 \\
438 \\
439 \\
440 \\
441 \\
442 \\
443 \\
444 \\
445\end{array}$ & 60 & $\left.\right|_{600} ^{6}$ & $\begin{array}{l}1.023 \\
1.023 \\
0.490 \\
0.493 \\
0.491 \\
0.491 \\
0.489 \\
0.490 \\
0.490 \\
1.021 \\
1.019 \\
1.024 \\
1.023 \\
1.023\end{array}$ & $\begin{array}{r}17.0 \\
149.0 \\
17.0 \\
63.0 \\
100.0 \\
152.0 \\
203.0 \\
131.0 \\
78.0 \\
8.0 \\
51.0 \\
99.0 \\
156.0 \\
132.0\end{array}$ & $\begin{array}{l}0.663 \\
0.940 \\
0.538 \\
0.591 \\
0.629 \\
0.687 \\
0.747 \\
0.652 \\
0.609 \\
0.747 \\
0.820 \\
0.948 \\
1.051 \\
0.998\end{array}$ & $\begin{array}{l}0.248 \\
0.159 \\
0.389 \\
0.364 \\
0.344 \\
0.318 \\
0.297 \\
0.322 \\
0.360 \\
0.264 \\
0.233 \\
0.213 \\
0.173 \\
0.186\end{array}$ & \\
\hline $\begin{array}{c}446 \\
447 \\
448 \\
449 \\
450 \\
451 \\
452\end{array}$ & 60 & 1400 & $\begin{array}{l}0.486 \\
0.487 \\
0.489 \\
0.489 \\
0.489 \\
0.490 \\
0.488\end{array}$ & $\begin{array}{r}21.0 \\
53.0 \\
103.0 \\
154.0 \\
197.0 \\
126.0 \\
77.0\end{array}$ & $\begin{array}{l}0.415 \\
0.45 y \\
0.505 \\
0.556 \\
0.592 \\
0.526 \\
0.471\end{array}$ & $\begin{array}{l}0.371 \\
U .358 \\
0.314 \\
0.275 \\
0.235 \\
0.294 \\
0.327\end{array}$ & \\
\hline $\begin{array}{l}476 \\
477\end{array}$ & 30 & 1 & $\begin{array}{l}1.026 \\
1.027\end{array}$ & $\begin{array}{l}13.0 \\
53.0\end{array}$ & $\begin{array}{l}0.777 \\
0.927\end{array}$ & $\begin{array}{l}0.159 \\
0.125\end{array}$ & \\
\hline
\end{tabular}


TABLE 1B

CRITICAL HEAT FLUX CONDITIONS NEW

NINE-ROD TEST CHANNEL 0.570-INCH-DIAMETER RODS

Heated
Length

Pressure Flow 2

Inlet

Heat Flux

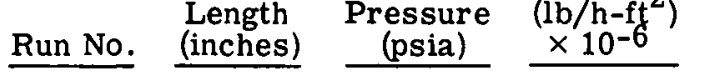

Subcooling

$\left(\mathrm{Btu} / \mathrm{h}-\mathrm{ft}^{2}\right)$

Exit

(Btu/lb)

N001

N002

N003

N004

N005

N006

N007

N008

N009

N010

N011

N012

N013

N014

N015

N016

N017

N018

N019

N020

N02 1

N022

N023

N024

N025

N026

N02 7

N028

N029

N030

N031

N032

N033

N034

N035

N036

N037

N038

N039

N040

N041

N042

N043

N044

.N045

N046

N047

N048

N049

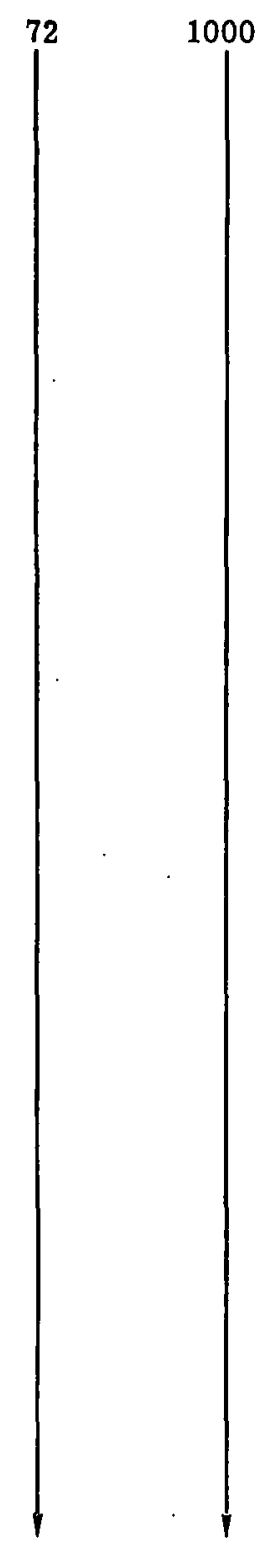

0.521 . 20.0

0.510

0.504

0.511

0.500

0.502

0.486

0.484

0.488

0.956

1.002

0.936

0.943

0.704

0.712

0.715

0.720

0.721

0.721

1.208

1.202

1.214

0.974

0.975

0.982

0.988

0.736

0.740

0.730

0.732

0.494

0.496

0.500

0.494

0.498

0.506

0.509

0.524

0.530

0.533

0.761

0.732

0.731

0.725

0.704

0.699

0.763

0.498

0.452
21.0

85.0

133.0

- 158.0

170.0

227.0

273.0

24.0

14.0

45.0

74.0

87.0

18.0

58.0

49.0

76.0

101.0

142.0

12,0

29.0

30.0

12.0

36.0

35.0

59.0

13.0

49.0

74.0

98.0

21.0

103.0

144.0

232.0

28.0

84.0

124.0

154.0

208.0

243.0

22.0

64.0

63.0

111.0

195.0

196.0

25.0

31.0

254.0
0.440

0.427

0.500

0.514

0.562

0.576

0.623

0.614

0.448

0.550

0.589

0.630

0.646

0.511

0.535

0.542

0.578

0.608

0.614

0.602

0.609

0.636

0.576

0.575

0.583

0.616

0.507

0.553

0.581 .

0.596

0.431

0.506

0.561

0.622

0.363

0.411

0.426

0.455

0.476

0.500

0.428

0.455

0.465

0.503

0.545

0.539

0.434

0.376

0.475
Quality

Remarks

0.457

0.453

0.443

0.378

0.408

0.402

0.391

0.310

0.494

0.310

0.294

0.275

0.262

0. 392

0.346

0.363

0.347

0.332

0.274

0.270

0.248

0.257

0.324

0.287

0.290

0.270

0.378

0.357

0.347

0.320

0.473

0.431

0.428

0.372

0.496

0.473

0.430

0.407

0.347

0.319

0.382

0.361

0.374

0.343

0.274

0.269

0.382

0.510

0.386

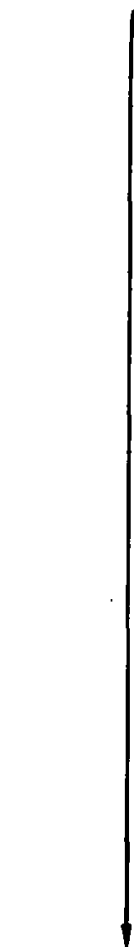

Runs N001 through

N034 are with a rod-to-wall clearance of 0.135 inch.

Runs N035 through N049 are with a rod-to-wall clearance of $0.060 \mathrm{inch}$. 


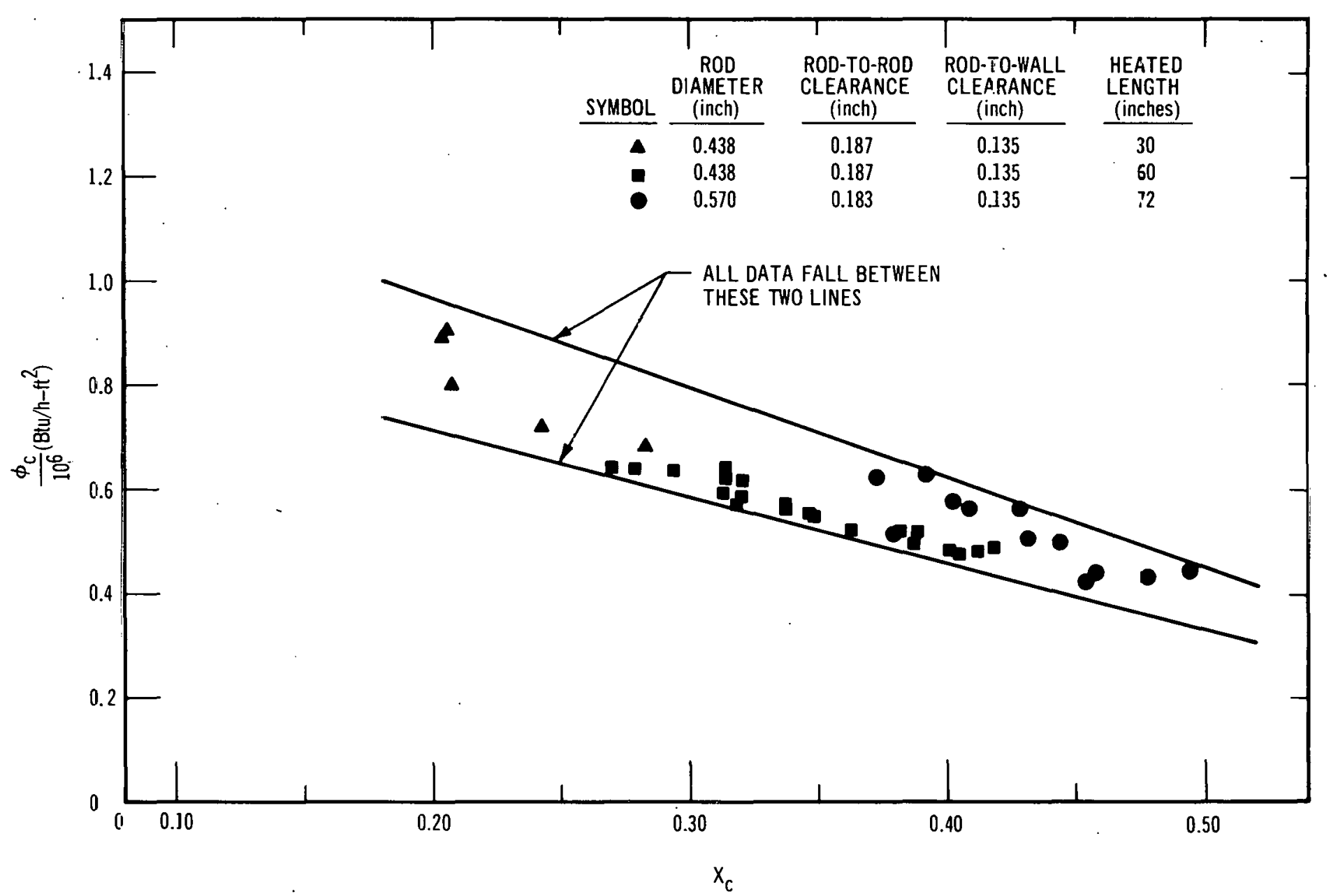




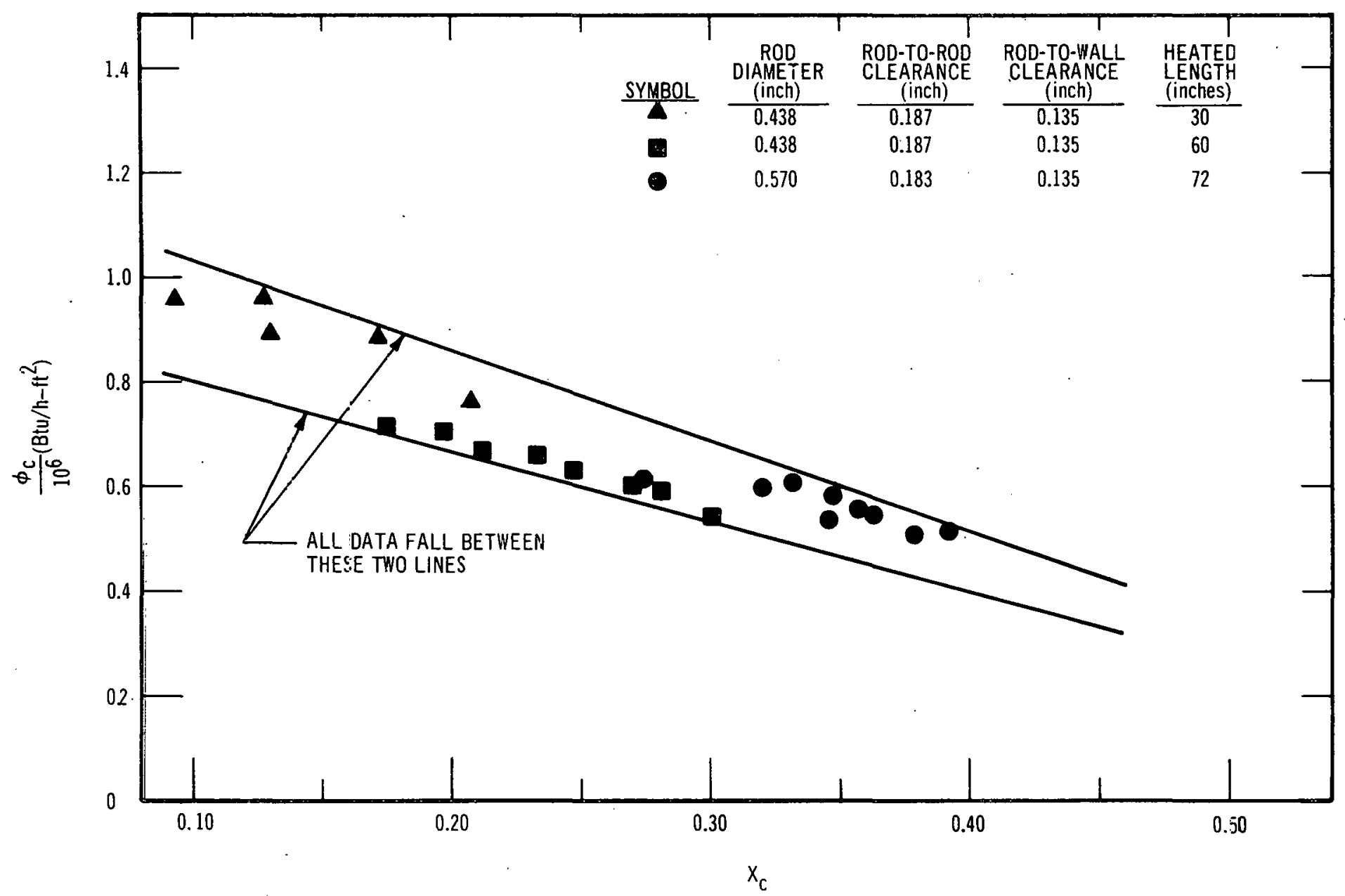




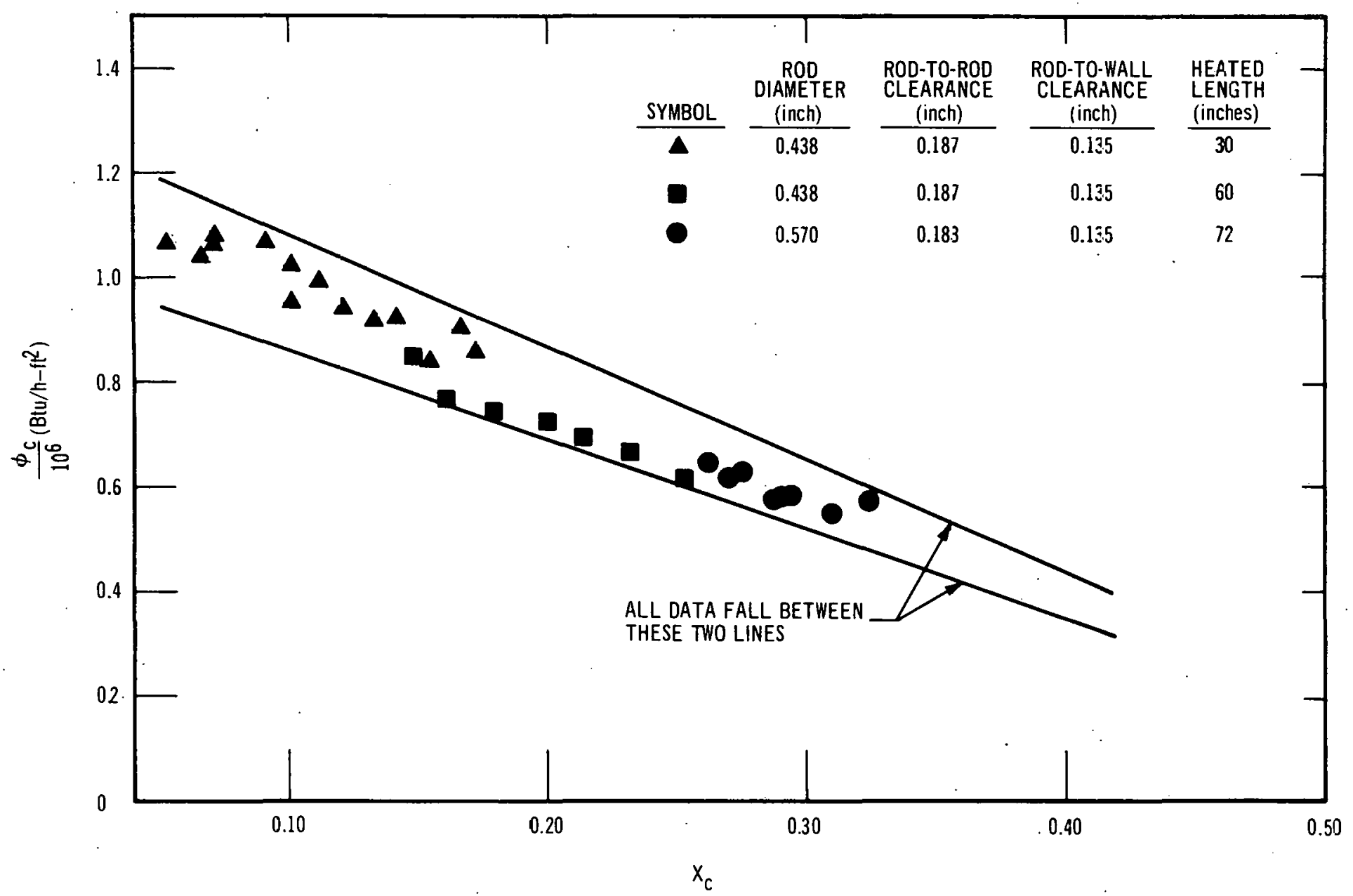




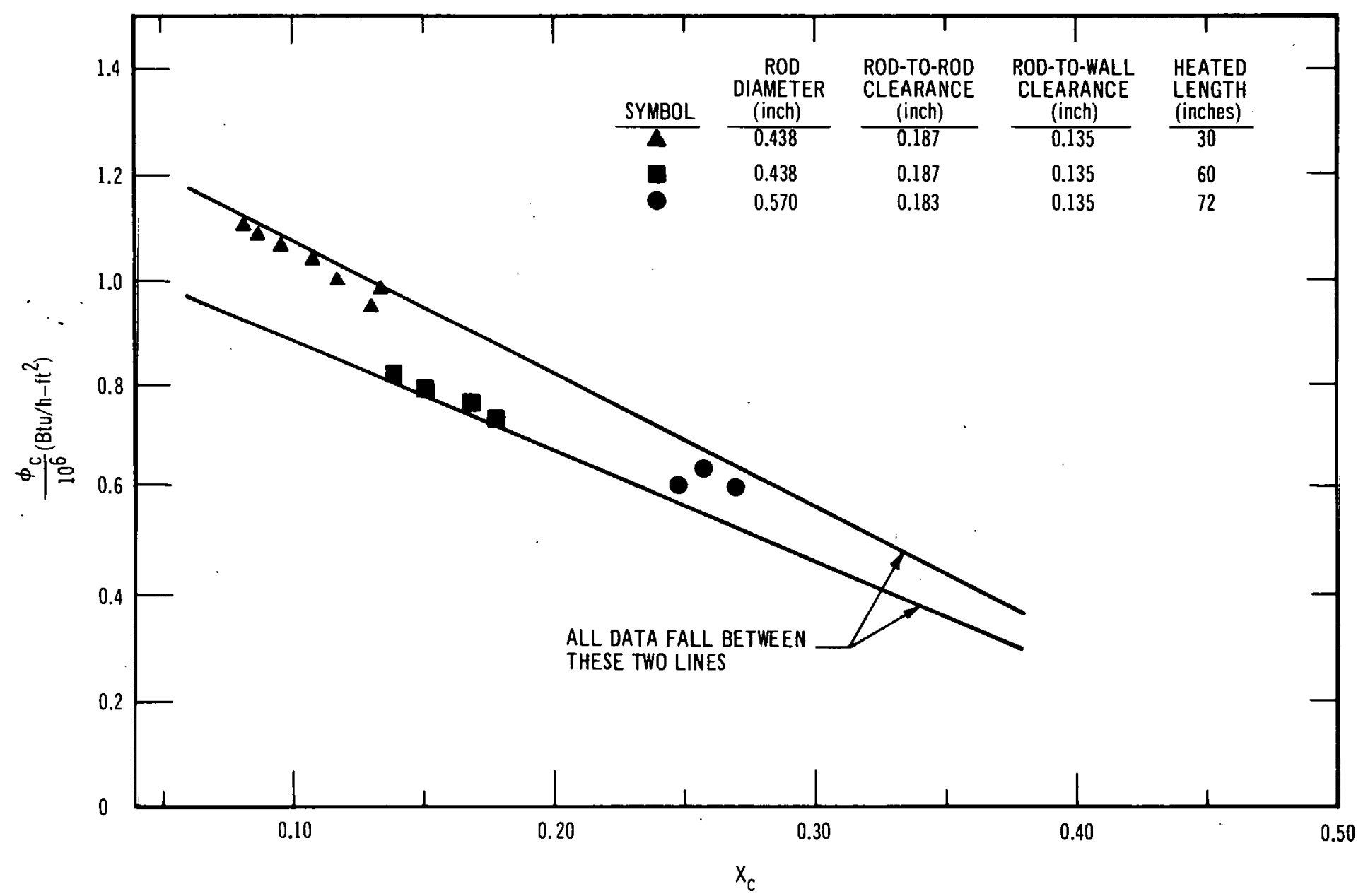




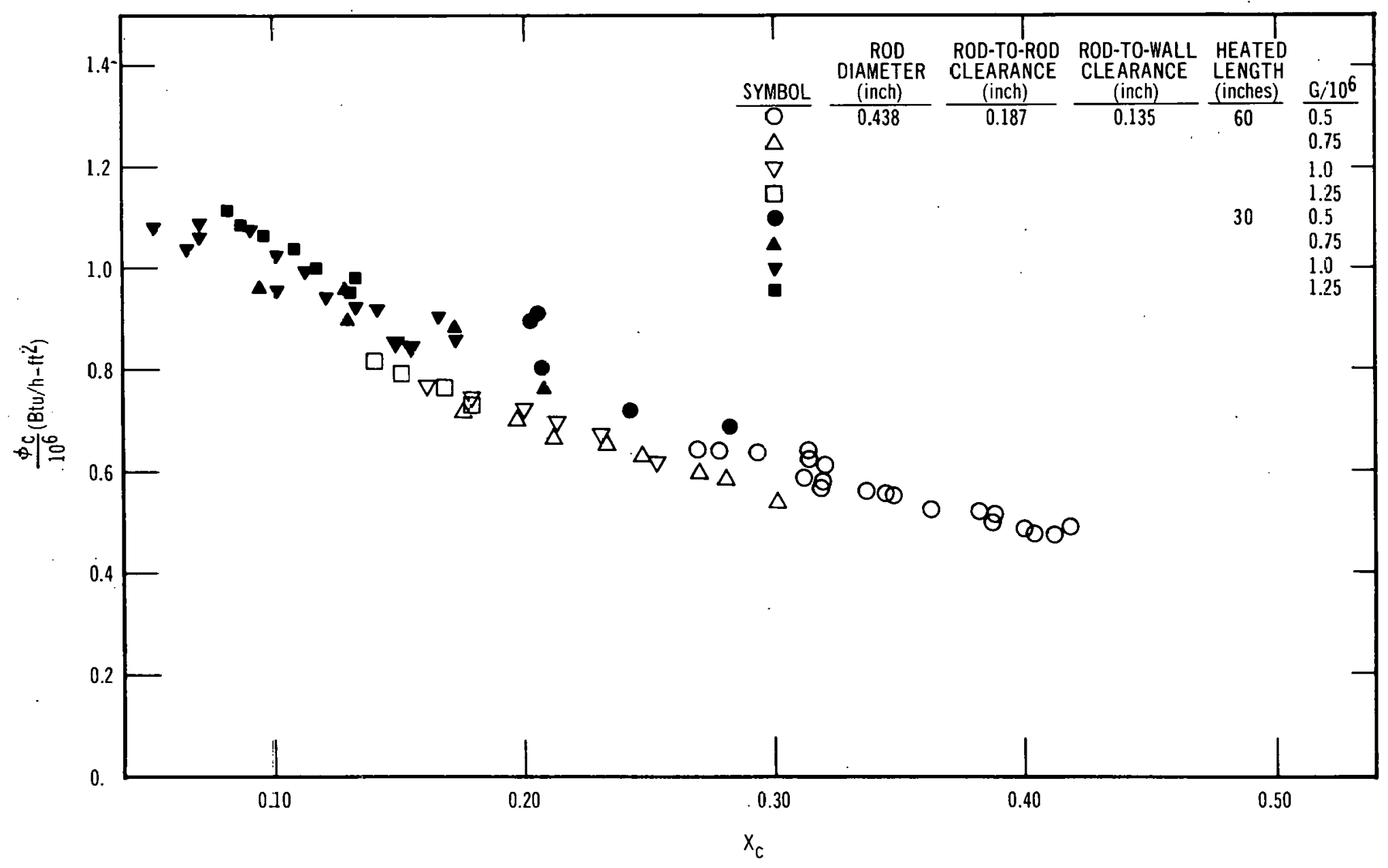




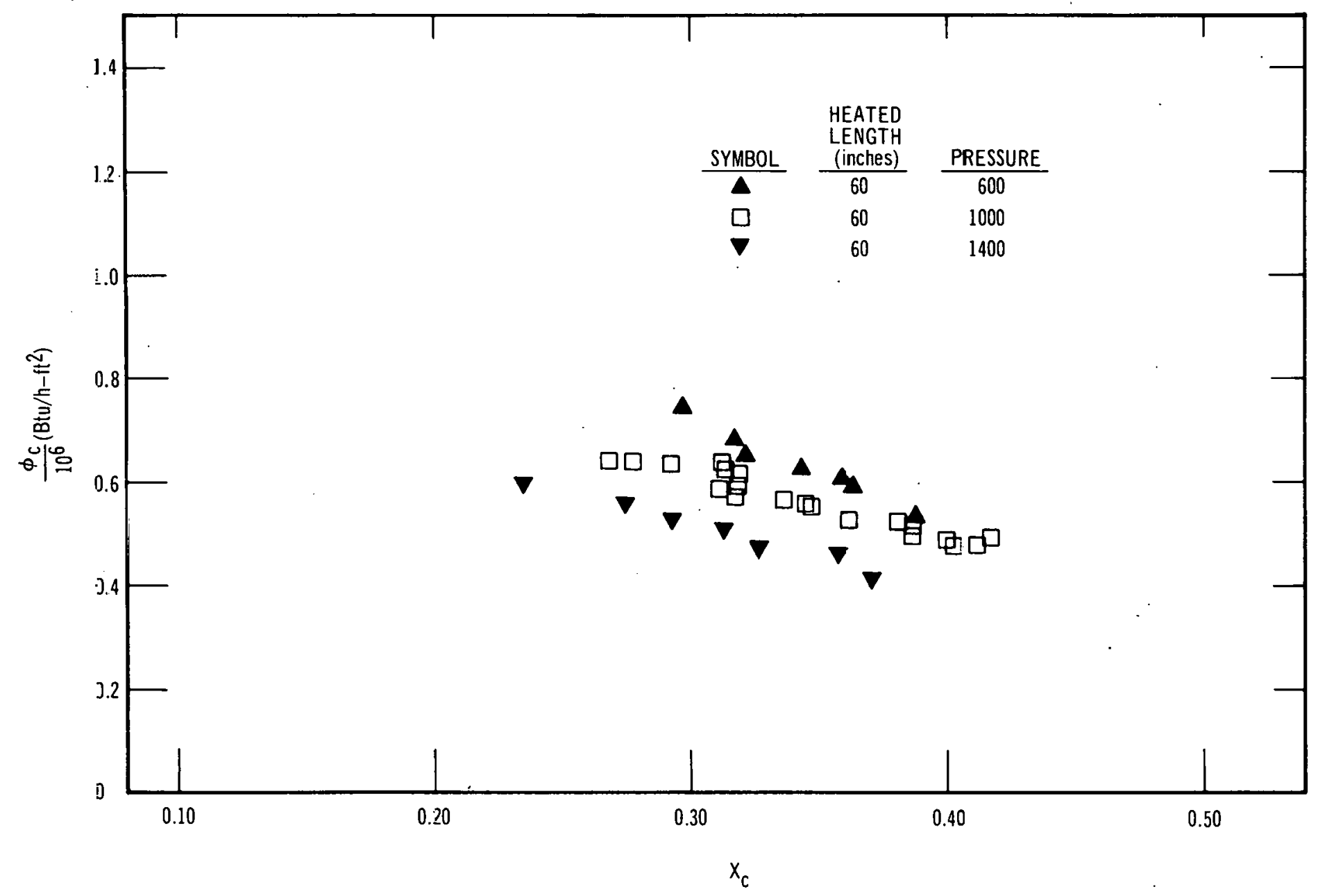




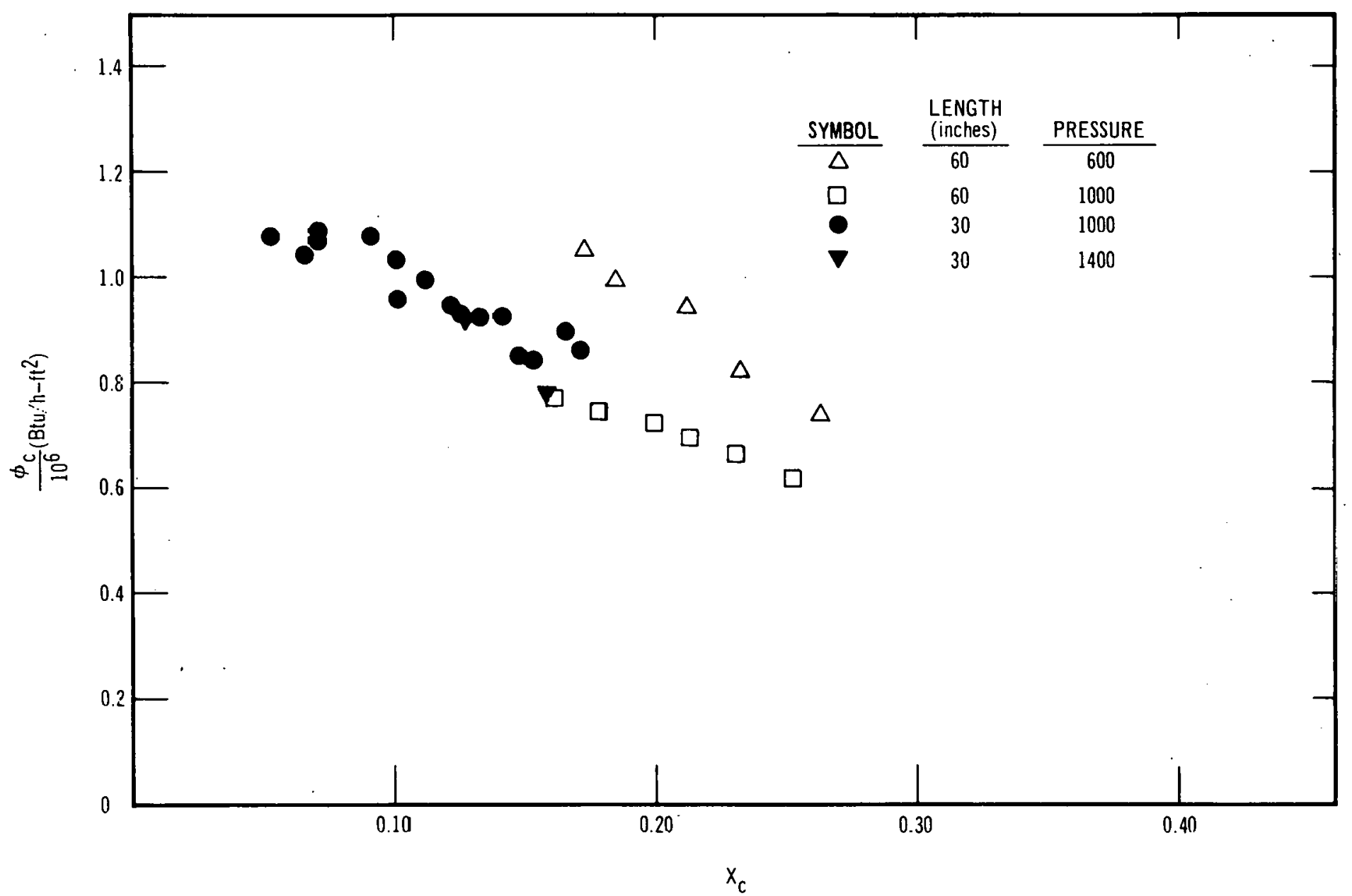




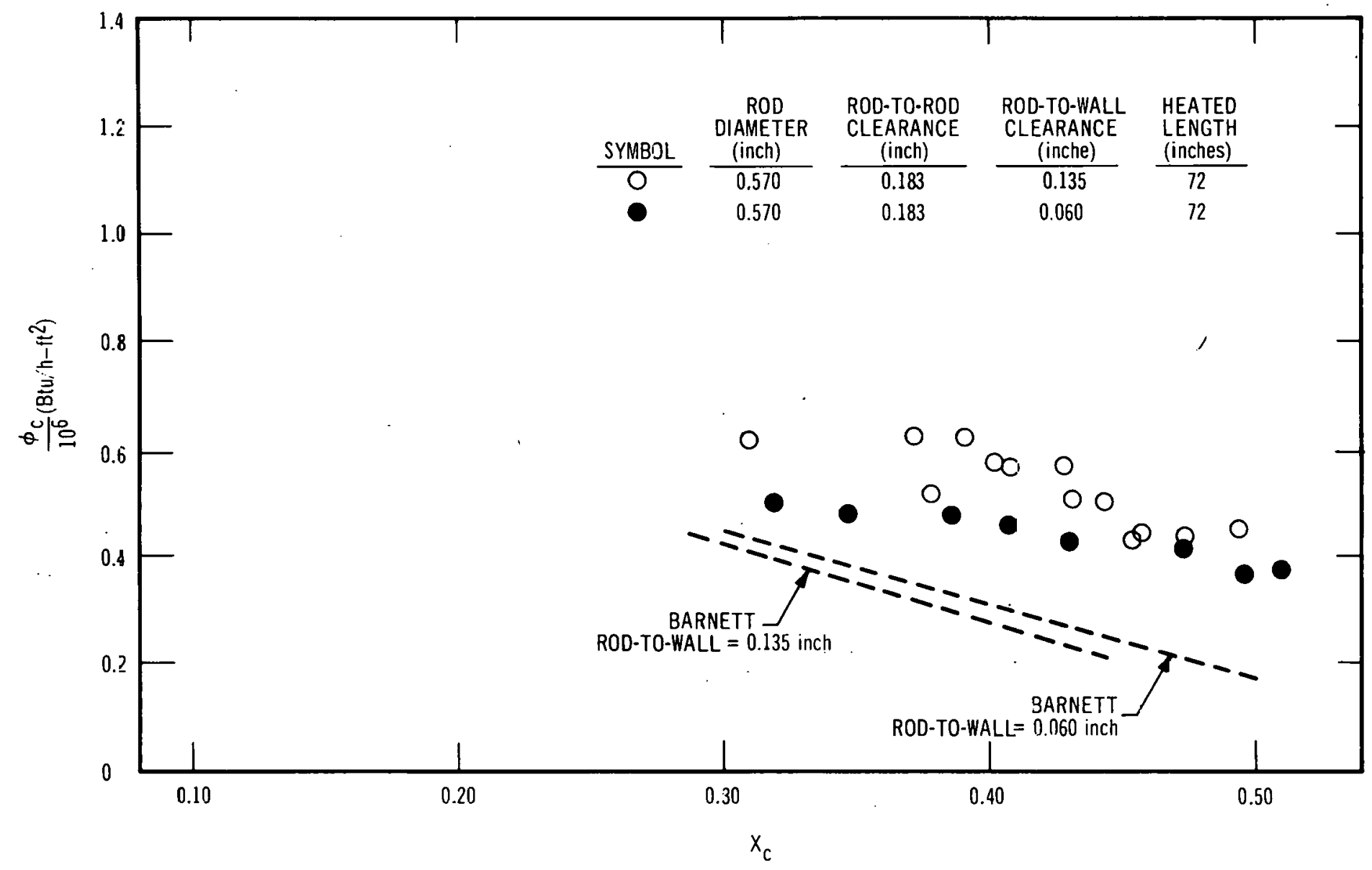




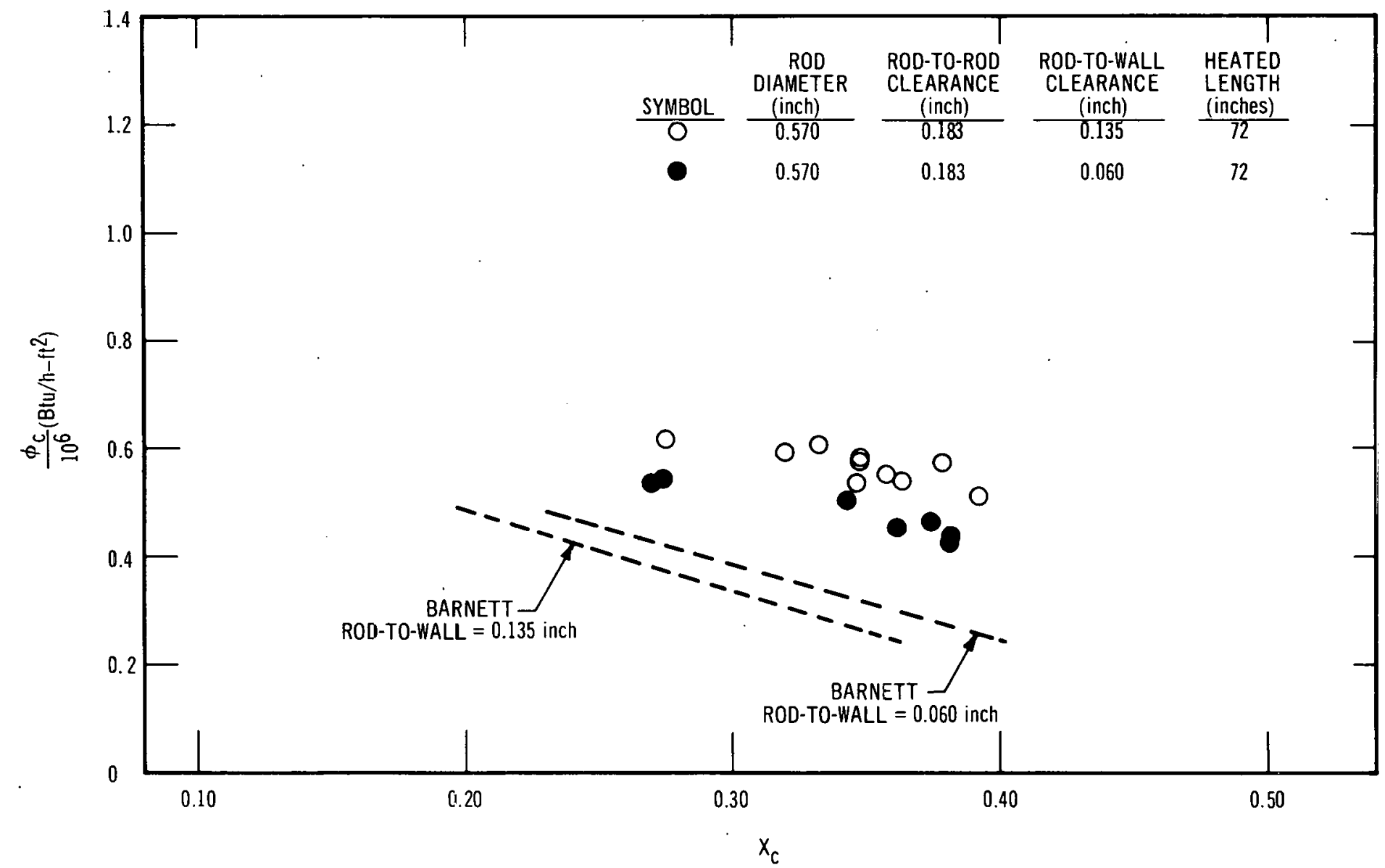


A comparison of the 60 -inch heated length data with the 72 -inch heated length data shows a reversal of the length effect described above; i.e., the CHF is lower with the shorter heated length. The 60 -inch heated length rods, in addition to being slightly shorter, were also slightly smaller in diameter than the 72 -inch rods $(0.4375$ inch instead of 0.570 inch). However, data taken with single rods $^{(3)}$ show no diameter effect.

On the evidence of the data plotted in Figures 4 through 7, it may be concluded that there is no strong or consistent length effect.

\subsection{Effect of Flow Rate}

Referring to Figure 8, the data show that for average channel flows of $0.75 \times 10^{6}$ $\mathrm{lb} / \mathrm{h}-\mathrm{ft}^{2}$ and higher, the CHF does not vary with flow, whereas for flows less than $0.75 \times 10^{6} \mathrm{lb} / \mathrm{h}-\mathrm{ft}^{2}$, the CHF tends to vary in an inverse manner with the flow. For example, in the range of qualities from 20 to $30 \%$, the CHF at $0.5 \times 10^{6} \mathrm{lb} / \mathrm{h}-\mathrm{ft}^{2}$ is the order of $10 \%$ higher than at $0.75 \times 10^{6} \mathrm{lb} / \mathrm{h}-\mathrm{ft}^{2}$. It appears, however, that the flow effect is not very strong, and it is shown in Figure 8 to be of the same order as the heated length effect.

\subsection{Effect of Pressure}

Referring to Figures 9 and 10, where the flow is $0.5 \times 10^{6} \mathrm{lb} / \mathrm{h}-\mathrm{ft}^{2}$, an increase in pressure from 1000 psia to 1400 psia causes about a $10 \%$ decrease in CHF, whereas a decrease in pressure from 1000 psia to 600 psia causes about a $10 \%$ increase in $\mathrm{CHF}$. There are fewer "pressure effect" data at a flow of $1 \times 10^{6} \mathrm{lb} / \mathrm{h}-\mathrm{ft}^{2}$ than at a flow of $0.5 \times 10^{6}$ $\mathrm{lb} / \mathrm{h}-\mathrm{ft}^{2}$, particularly at $1400 \mathrm{psia}$, and the length effect tends to mask the pressure effect. However, the general effect of pressure at the higher flow appears to be the same as at the lower flow. In the range of pressures from 600 to $1400 \mathrm{psia}$, the CHF varies in an inverse manner with pressure, other things being the same.

\subsection{Effect of Rod-to-Wall Spacing}

Referring to Figures 11 and 12 , for flows in the range $0.5 \times 10^{6}$ to $0.75 \times 10^{6}$ $\mathrm{lb} / \mathrm{h}-\mathrm{ft}^{2}$ and qualities from 30 to $50 \%$, a reduction in rod-to-wall clearance from 0.135 inch to 0.060 inch by installing a 0.070 -inch liner in the new test channel (refer to Section III) causes a reduction in CHF of $15 \%$.

It should be pointed out that the rod-towall clearances mentioned above, at the location of $\mathrm{CHF}$ and the time of $\mathrm{CHF}$, could have been several thousandths of an inch in error. It will be noted from the description of the new test channel that the distance between supports at the top end of the rods (the last set of pins and the top tie plate) is 19 $5 / 8$ inches. It was apparent from the dark appearance of some of the rods at the termination of the tests with the 0.135 -inch rodto-wall clearance, that a few of them had experienced high temperature gradients, and thermal bowing must have occurred. Rod G had even taken on a parmanent inward bow at room temperature of an estimated $0.02 \mathrm{inch}$. Rod C, however, was installed new just before the 0.070 -inch liner tests. The rod $\mathrm{C}$ thermocouples were the ones which indicated $\mathrm{CHF}$ for all the subsequent 0:070-inch liner runs. At the end of these runs, rod $C$ showed little evidence of over-heating, and was not bowed. It is believed that any bowing of rod $\mathrm{C}$ during the runs was negligible and that the results correctly show the effect of reduced rod-to-wall clearance on $\mathrm{CHF}$. 


\section{COMPARISON WITH OTHER MULTIROD RESULTS}

The direct measurement of CHF for multirod geometries has now been done at a number of laboratories. Some of the best of these data are listed in References (4) and (5). Salient features of the test channels for certain data selected from these two references (19-rod, 37-rod, and seven-rod bundles in a circular array with rod-to-rod and rod-towall spacings comparable to the spacings for our nine-rod square array bundles) are summarized in Table 2. The data are plotted in Figures 13 through 16 . Superposed are shaded areas to indicate the location of the nine-rod data reported here.

Agreement between the multirod data of Figures 13 through 16 with our nine-rod data is poor, on the basis of average exit quality and mass velocity. Only four of the multirod data points, from a total of 125 , lie within the shaded areas. It is evident that for correlation purposes, where the data have been obtained with other than square arrays of rods, this way of presenting multirod CHF results (i.e., versus average exit quality and mass velocity) has limitations as will be discussed later.

Matzner and Casterline ${ }^{(8)}$ tested a series of 19-rod (circular array) bundles at various pressures from 500 psia to 1200 psia and flows from $0.1 \times 10^{6}$ to $3.0 \times 10^{6} \mathrm{lb} / \mathrm{h}-\mathrm{ft}^{2}$. The heat flux on the inner rods and center rod was in all cases approximately $71 \%$ of the flux on the outer circle of rods. The rod-to-rod clearance was $0.040 \mathrm{inch}$, and the rod-to-wall clearance was $0.060 \mathrm{inch}$, which is a much more compact array than out nine-rod bundle or the bundles listed in Table 2. The results are summarized in their conclusions:
"At the very low mass velocities of 0.1 and $0.2 \times 10^{6} \mathrm{lb} / \mathrm{h}-\mathrm{ft}^{2}$, the critical heat flux was practically independent of mass velocity, pressure, and length, and linearly dependent on only exit quality from 45 to $95 \%$.

"At mass velocities of $0.5 \times 10^{6} \mathrm{lb} / \mathrm{h}-\mathrm{ft}^{2}$ and greater, the following trends were apparent:

1. At constant exit quality, mass velocity, and length, the critical heat flux increased with decreasing pressure from 1200 to 500 psia.

2. At constant exit quality, mass velocity, and pressure, the critical heat flux decreased with increasing length from 19 inches to 9 feet.

3. At constant exit quality, pressure, and length, the critical heat flux increased with increasing mass velocity from 0.5 to $3.0 \times 10^{6} \mathrm{lb} / \mathrm{h}-\mathrm{ft}^{2}$.

4. The slopes of the critical heat flux versus exit quality curves for all the test sections were smaller than usual.

5. As the bundle length was increased from 18 inches to 9 feet, the critical heat flux location shifted from the outer rods to the center rod despite a $30 \%$ heat flux depression on the center and inner rods.

"It has been postulated that the performance of these bundles was strongly dependent on the rods in the bundle closely spaced (large $\mathrm{D} / \mathrm{s}$ ratio), thus minimizing subchannel mixing. Lack of mixing then allowed substantial enthalpy imbalance to develop in the subchannels of the bundle which resulted in a lower critical heat flux performance than had been observed for low $\mathrm{D} / \mathrm{s}$ ratio bundles." 
TABLE 2

SELECTED ROD BUNDLES FOR WHICH CHF DATA AT 1000 PSLA ARE AVAILABLE

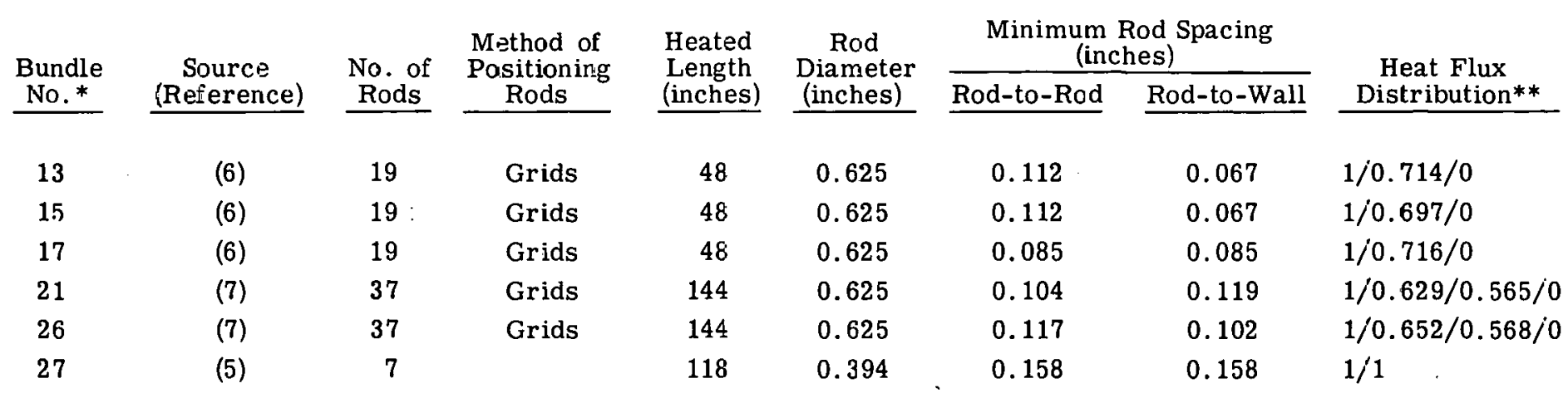

* The bundle numbering scheme is the same as used in Reference (4). Bundle No. 27 has been added to the original listing.

** Rods are arranged in circles. The heat flux distribution is in the radial direction, from outer circle to center. 


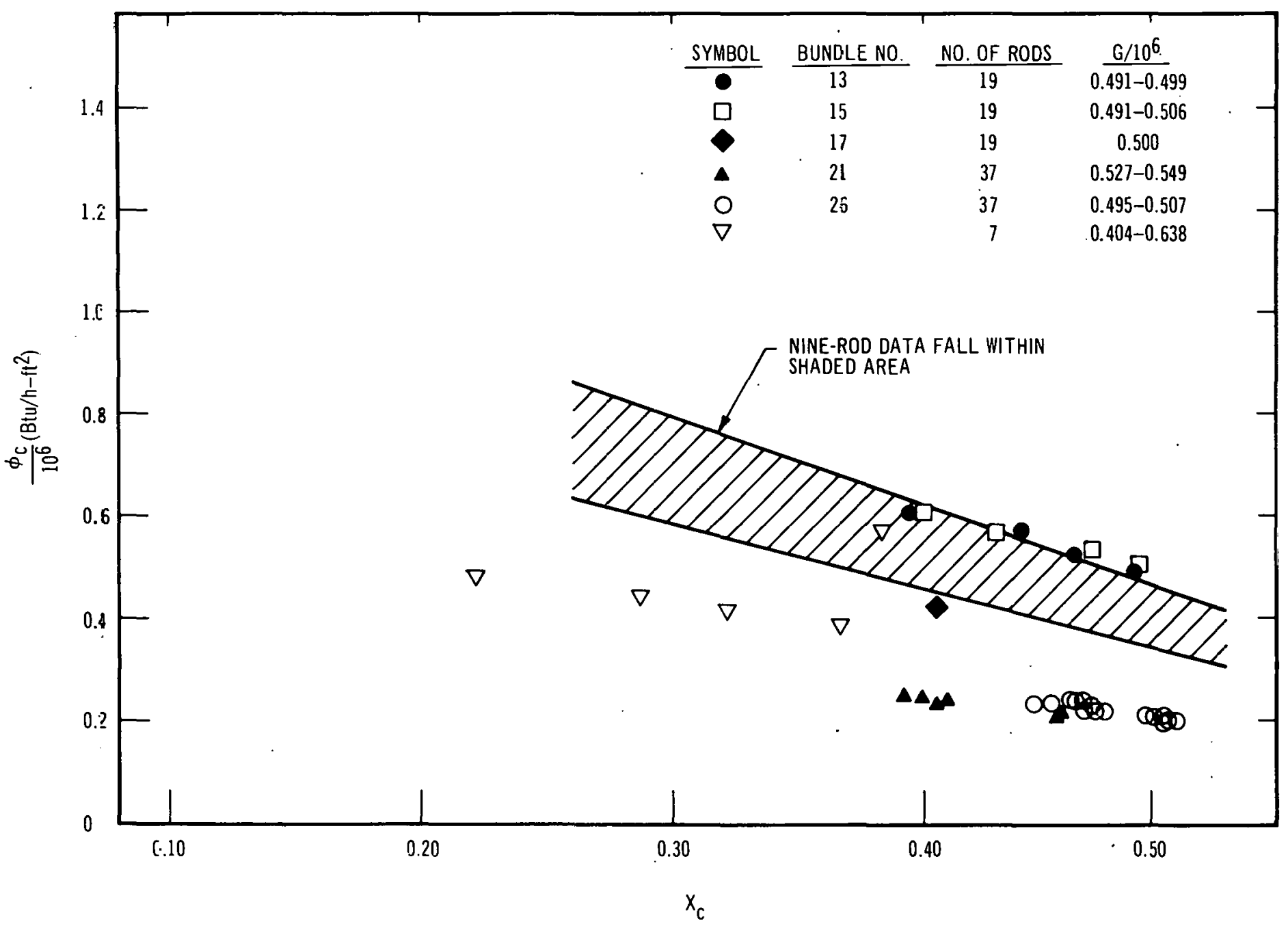




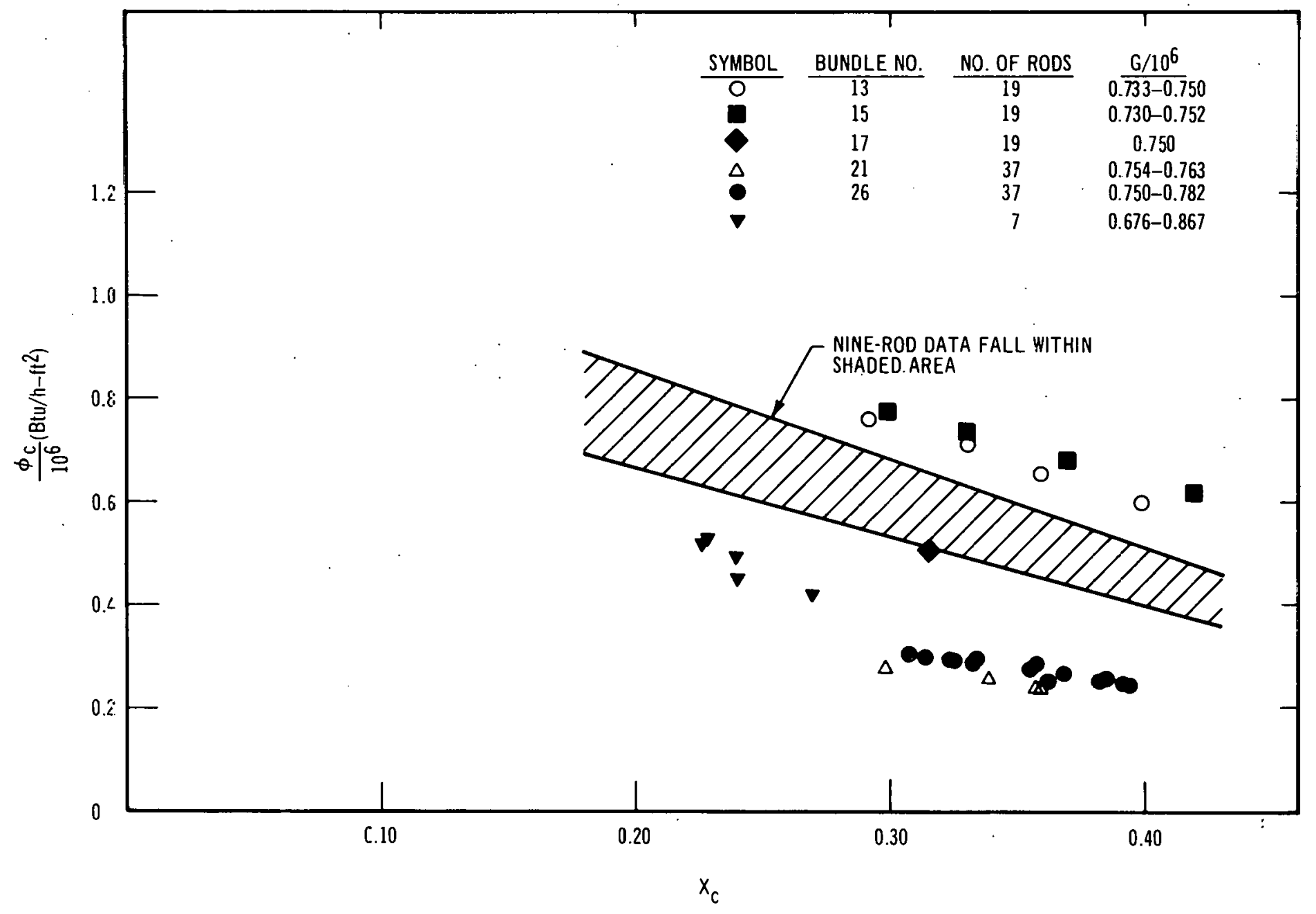




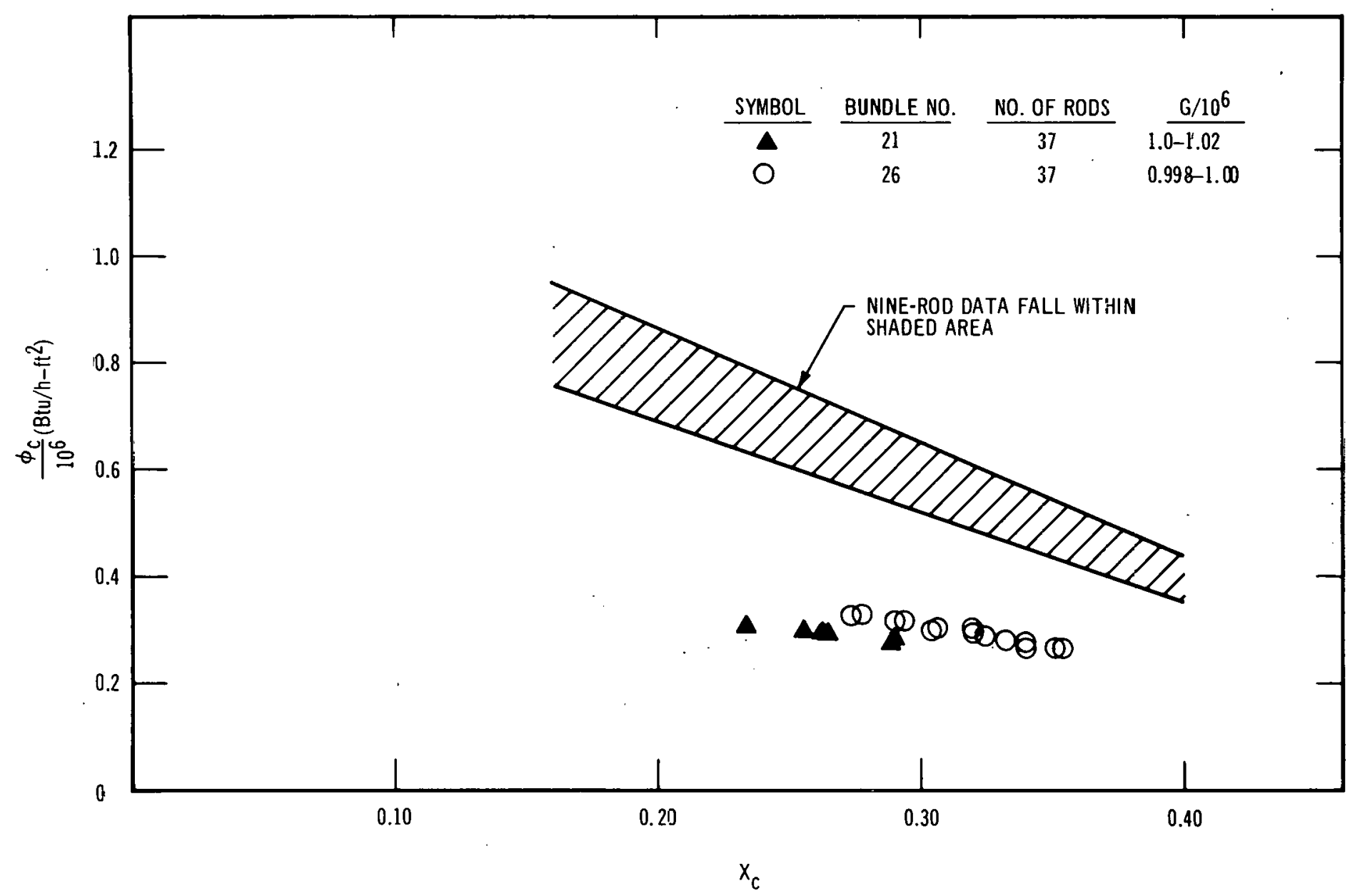




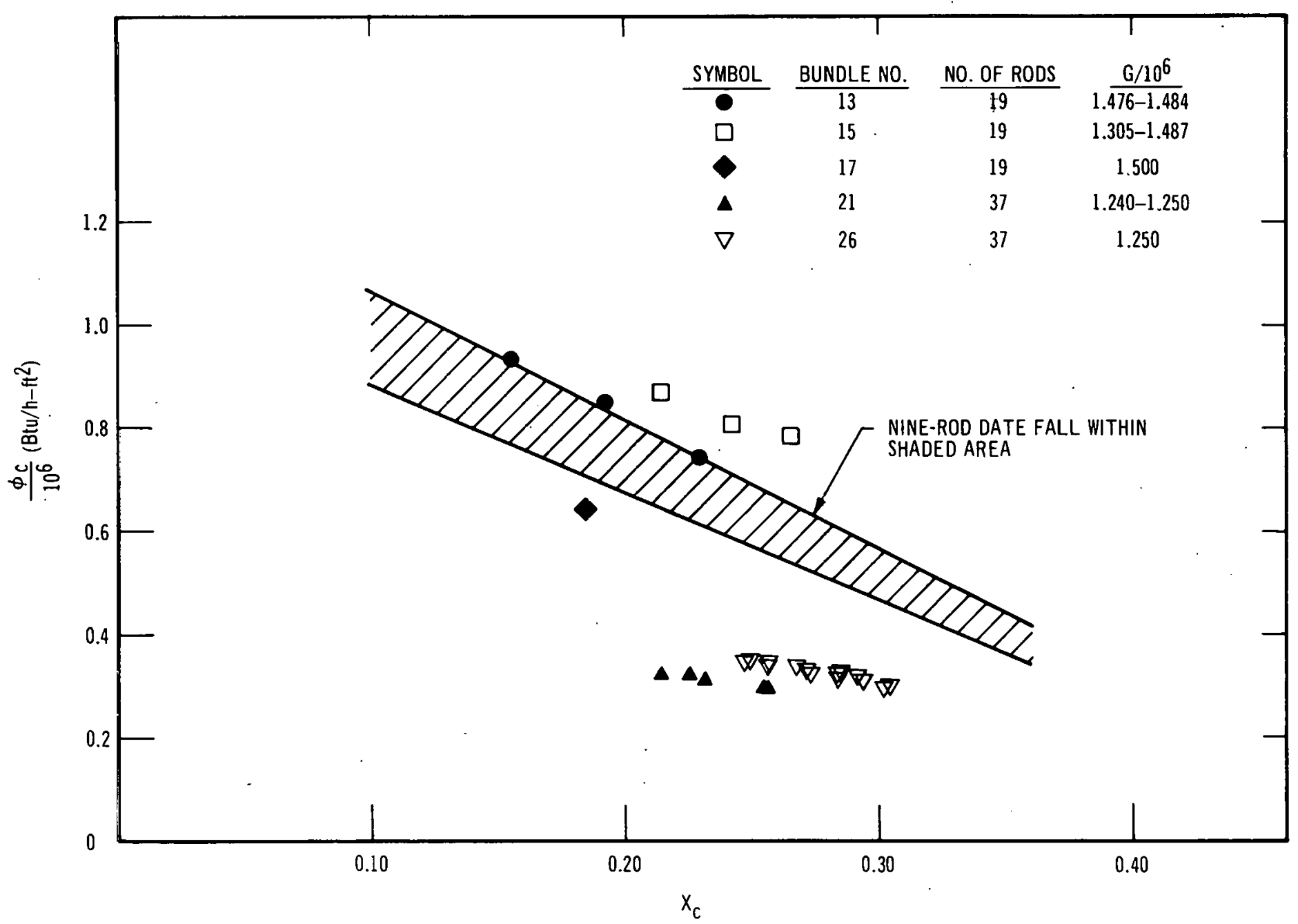


Concerning Item 5 of the above quoted conclusions, it was apparent from the Columbia data that the CHF location also tended to shift from the outer rod toward the center rod with a decrease in flow and, to a slight extent, with increase in quality.

Our nine-rod results show: a.) the same CHF effect with pressure as noted in Item 1, b.) no definite length effect, except that the decrease in CHF with increase in length from 30 inches to 60 inches at the higher flows agrees with Item 2, c.) no strong flow effect, except that the decrease in CHF with increase in flow from $0.5 \times 10^{6}$ to $0.75 \times 10^{6}$ is the reverse of the trend noted in Item 3 , and d.) no tendency for the CHF location to shift toward the center with any change in length, flow, or quality. It is presumed that the difference between our nine-rod results and the Columbia 19-rod results is due primarily to the much closer spacing of the latter, which is in line with the conclusion drawn by Matzner and Casterline relative to the generally lower level of the CHF which they observed.

Becker ${ }^{(9)}$ has correlated a considerable amount of multirod CHF data, most of which was obtained with bundles in circular array, by means of a correlation of round tube data. Becker's round tube correlation is of the form

$x_{c \text { (round) }}=a_{0}\left[\frac{10^{9}}{\mathrm{G}^{1 / 2} \phi_{c}}-a_{1}\right]$,

where $a_{0}$ and $a_{1}$ are functions of pressure. For a multirod bundle,

$\mathrm{x}_{\mathrm{c}}=\mathrm{x}_{\mathrm{c} \text { (round) }} \eta \eta_{1} \eta_{2}$

where

$\eta=\frac{\text { Heated perimeter }}{\text { Total wetted perimetcr }}$,

$\eta_{1}=\eta_{1}\left(\phi_{c}\right)$ [See Figure 14 of Reference (9)] , and

$\eta_{2}=0.68$ for multirod bundles.
The heat balance equation is

$\phi_{c}=\frac{\eta \mathrm{GD}_{\mathrm{HY}}{ }^{\mathrm{h}} \mathrm{fg}}{4 \mathrm{~L}}\left[\frac{\Delta \mathrm{h}_{\mathrm{s}}}{\mathrm{h}_{\mathrm{fg}}}+\mathrm{x}_{\mathrm{c}}\right]$.

Equations (1), (2), and (3) are solved together for $\phi_{c}$ and $x_{c}$. Becker suggests that this correlation may be used for nonuniform axial flux as well as uniform. For nonuniform radial flux, $\eta$ is redefined

$\eta=\frac{\frac{1}{\mathrm{n}} \sum_{\mathrm{i}=1}^{\mathrm{n}} \xi \times \text { Heated perimeter }}{\text { Total wetted perimeter }}$,

where

$\mathrm{n}=$ Number of rods, and

$\xi=$ Ratio, heat flux on $\mathrm{i}^{\text {th }}$ rod to maximum heat flux.

Barnett ${ }^{(4)}$ has also correlated multirod CHF data, but by means of a correlation of internally-heated annulus data, in contrast to the round tube correlation used by Becker.

The method involves choosing, for the particular multirod bundle, an equivalent inner diameter $\mathrm{D}_{\mathrm{I}}$ * and equivalent outer diameter $\mathrm{D}_{0}{ }^{*}$, and then treating the bundle as an annulus.

According to Method II of Reference (4),

$D_{I}^{*}=D_{R}$, and

$\mathrm{D}_{\mathrm{O}}^{*}=\left\{\mathrm{D}_{\mathrm{R}}\left(\mathrm{D}_{\mathrm{HE}}+\mathrm{D}_{\mathrm{R}}\right)\right\}^{1 / 2}$

where

$\mathrm{D}_{\mathrm{HE}}=\frac{4 \times \text { Flow area }}{\pi \mathrm{D}_{\mathrm{R}} \sum_{i=1}^{\mathrm{n}} \zeta}$,

and $\mathrm{n}$ and $\xi$ are as defined above.

The hydraulic diameter $\mathrm{D}_{\mathrm{HY}}$ has the usual definition

$\mathrm{D}_{\mathrm{HY}}=\frac{4 \times \text { Flow area }}{\text { Total wetted perimeter }}$. 


$$
\begin{aligned}
& \text { Note, per Equations (4), (7), and (8), } \\
& \text { that } \\
& \frac{\mathrm{D}_{\mathrm{HY}}}{\mathrm{D}_{\mathrm{HE}}}=\eta \text {. }
\end{aligned}
$$

The schemes for accounting for radial flux variation employed by Becker and by Barnett are essentially the same.

The internally-heated annulus correlation used by Barnett has the form

$\frac{\phi_{c}}{10^{6}}=\frac{A+B \Delta h_{s}}{C+L}$,

where $\mathrm{A}, \mathrm{B}$, and $\mathrm{C}$ are functions of $\mathrm{D}_{\mathrm{HE}}, \mathrm{G}$, and $D_{H Y}$. They are presumably also functions of pressure, but only the single pressure, 1000 psia, was considered in Reference (4).

One difference between the Becker and Barnett correlation methods which is immediately apparent is that the Becker model is independent of heated length, whereas the Barnett model has a length dependence. Other differences become apparent in the application of the two correlations.

CHF predictions based on these two correlations, for the same conditions as the ninerod tests, are plotted in Figures 17 through 20 . Shaded areas corresponding to the nine-rod data are superposed. The correlations for the two lower flows (Figures 17 and 18) for a heated length of 30 inches were calculated using a uniform radial heat flux, consistent with most of the 30-inch data at the same two flows. The correlations for the remainder of the 30-inch, and all of the 60-inch cases were calculated using one hot rod (approximately 10\% higher in heat flux than the other rods), again consistent with the data.

Both the Becker and Barnett correlations lie generally below the data. In the low-quality region, where the data were (necessarily) obtained with the short (30-inch) heated length, the Becker correlation does a fair job; the Barnett correlation is low. In the middle quality region, where the data were obtained with the 60-inch heated length, both correlations are low with respect to the data, but are in good agreement with each other.

It will be noted that there is a discontinuity between the Barnett correlations for the 30 -inch and 60-inch heated lengths. This is due both to the difference in length and, at the lower flows, the difference in radial flux distribution. The discontinuity has nearly disappeared at the two higher flows (Figures 19 and 20). The corresponding discontinuity for the Becker correlations is much less pronounced, is due only to difference in radial flux distribution, and hence exists only at the two lower flows.

The Barnett correlation has been superposed on the graphs of Figures 11 and 12, which show the effect of reducing the rod-to-wall clearance from 0.135 inch to 0.060 inch. The correlation is only affected by the reduction in channel flow area. It predicts a 10 to $15 \% \mathrm{im}-$ provement in $\mathrm{CHF}$, whereas the test results show the opposite effect, i.e., a $15 \%$ reduction in CHF.

Both correlations are based largely on data for bundles in a circular array, and both consider only average quality and mass velocity. It has already been pointed out that agreement between other multirod (circular array) data and our nine-rod data is poor when compared on the basis of average quality and mass velocity. Agreement between the Becker and Barnett correclations and our nine-rod data is also poor, on the same basis. It is evident that for a general correlation scheme the average channel conditions are not enough. A more detailed consideration of conditions is needed for CHF prediction in multirod geometries. Fortunately, such a detailed consideration, in which the channel is divided into a number of subchannels, is now receiving attention at a number of $R$ and $D$ centers. The conditions in each of the subchannels are con: sidered rather than treating the channel as a whole. The pertinence of this work to our ninerod results will be discussed in Section VI. 


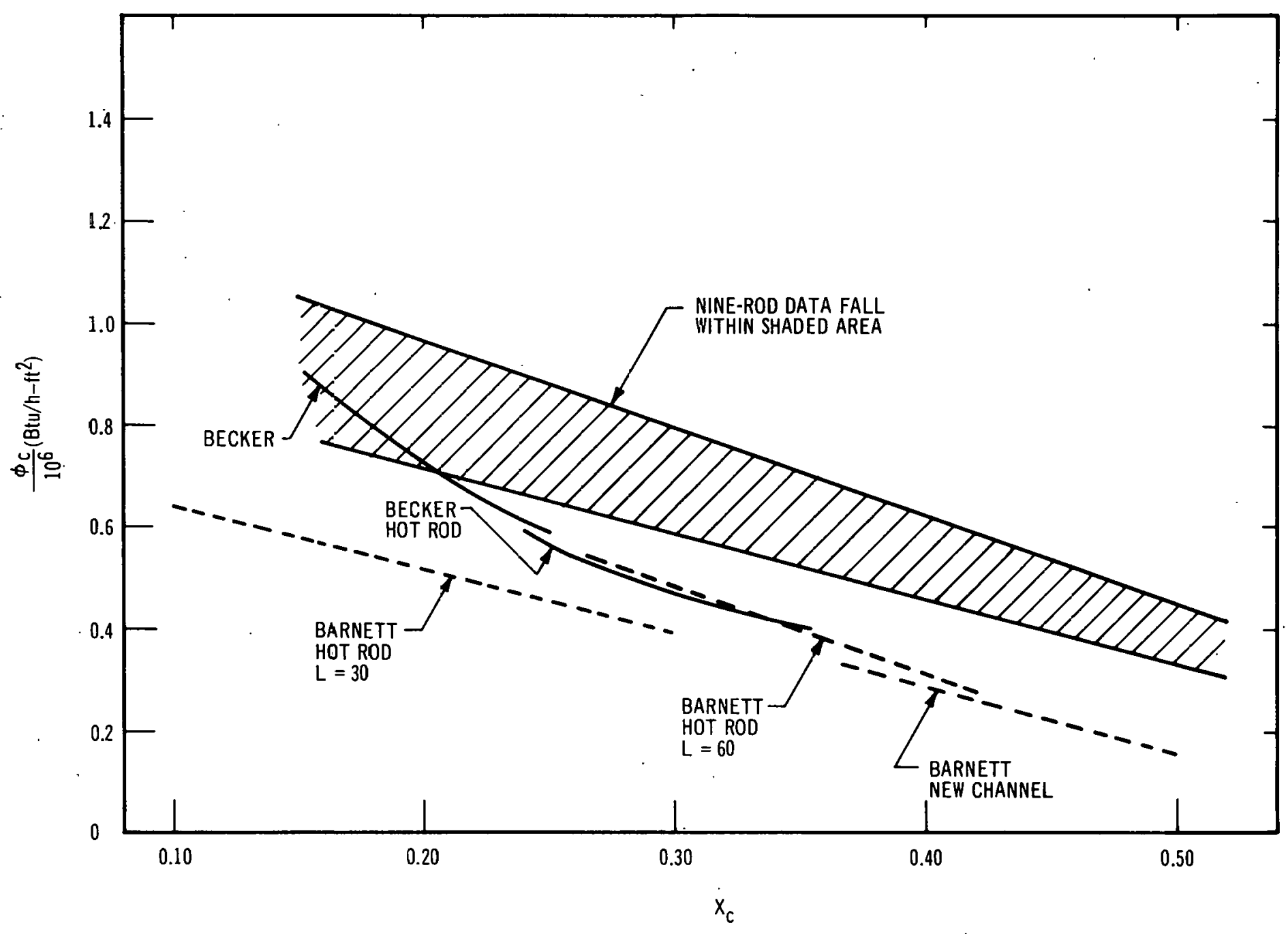




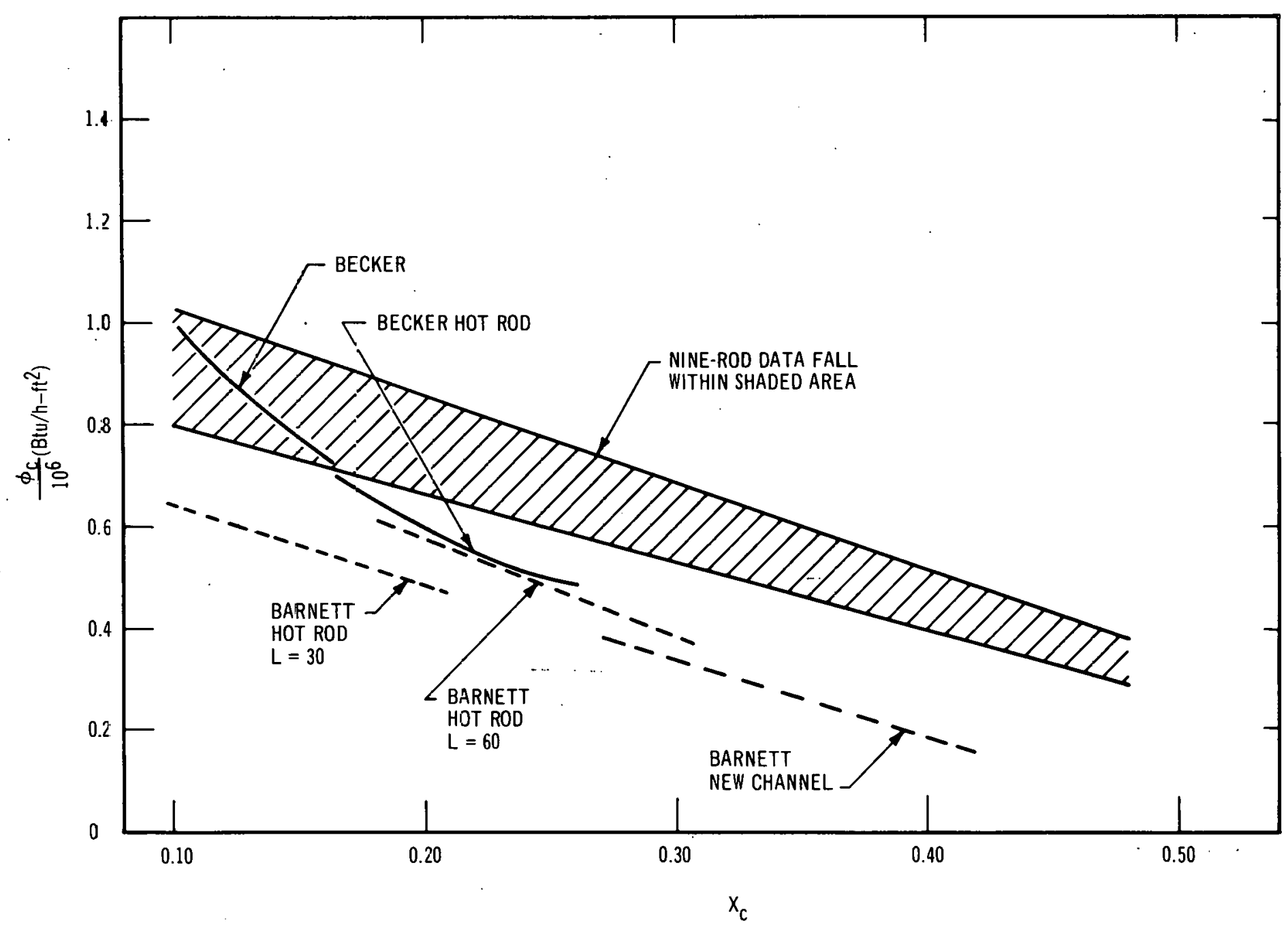




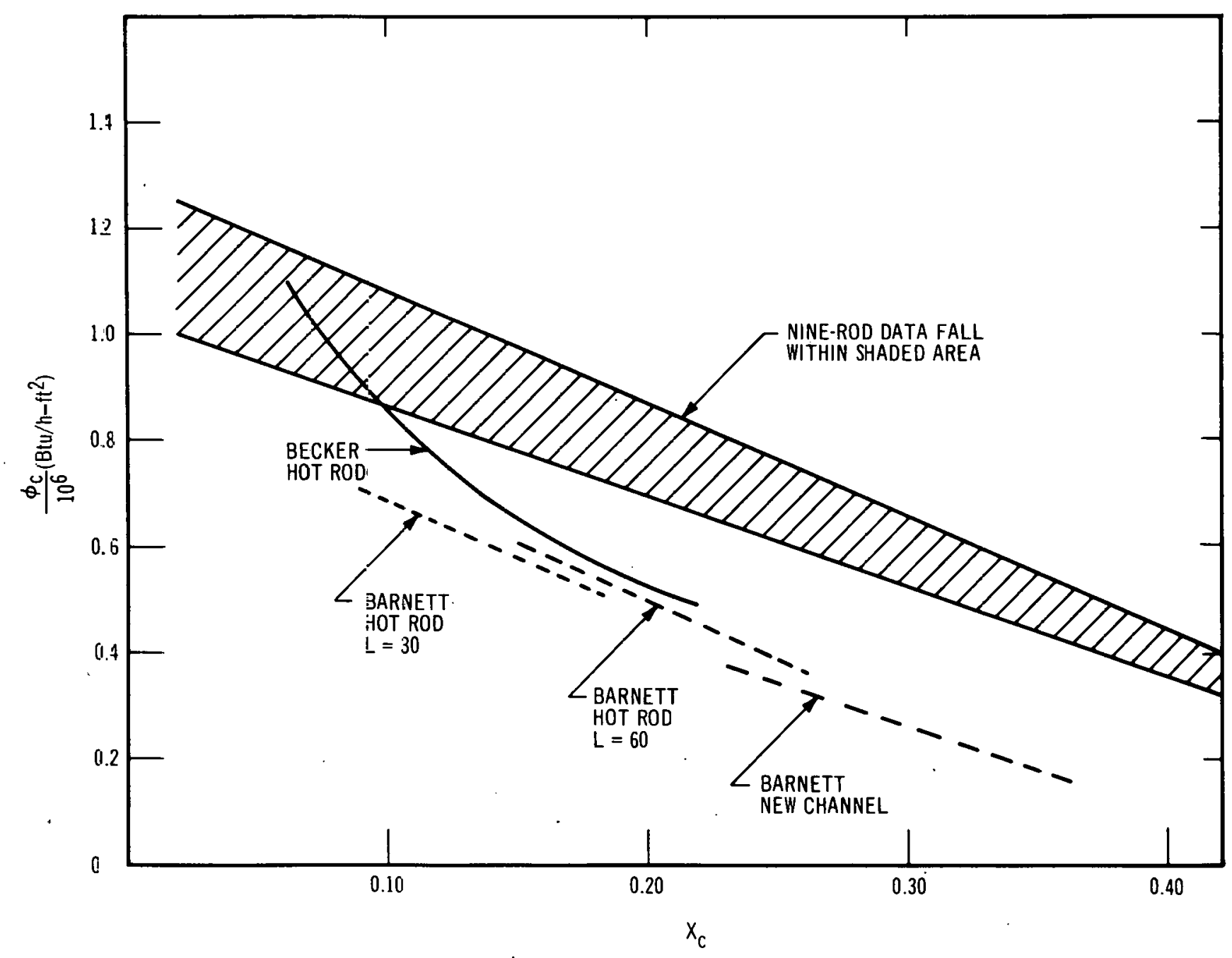

$\frac{9}{1}$
$\frac{1}{0}$
$\frac{1}{\alpha}$
$\frac{\alpha}{\alpha}$

FIGURE 19. CRITICAL MEAT FLUX VERSUS QUALITY AT $1000 \mathrm{psio,} 1.0 \times 10^{6} \mathrm{lb} / \mathrm{h}-\mathrm{ft}^{2}$, TWO CORRELATIONS 


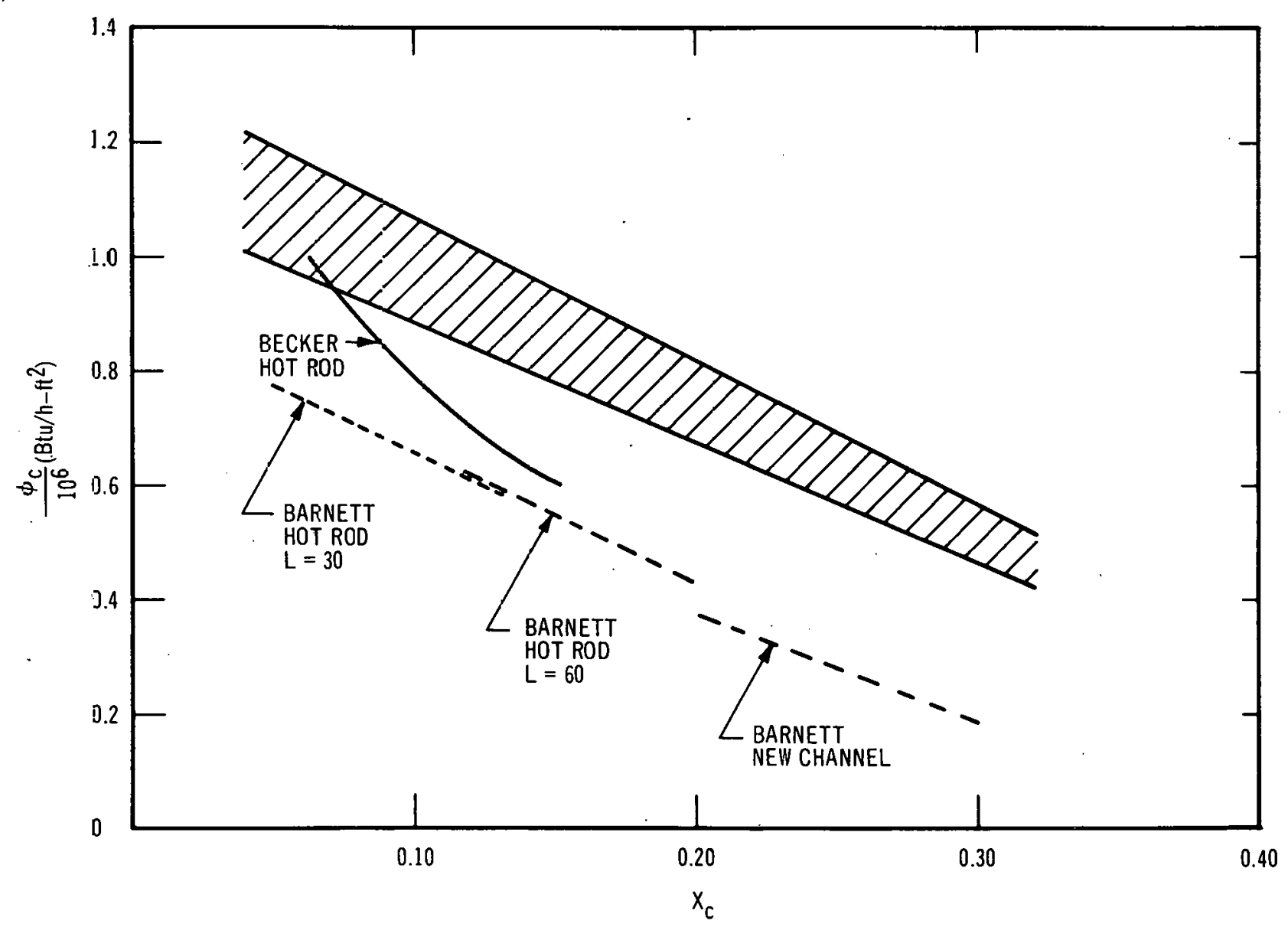




\section{SECTION VI}

\section{EVALUATION OF MULTISUBCHANNEL COMPUTER CODES}

A multirod channel can be divided into two or more subchannels. The location of the imaginary surfaces which separate each subchannel from its neighbors can be selected quite arbitrarily. It is customary, however, to locate each such surface at the narrowest position along the passage connecting the two subchannels. Thus, a nine-rod channel may be divided into as many as 16 subchannels as shown in Figure 21. It is also possible to take advantage of symmetry and consider as few as three* subchannels, provided all the rods are. uniformly heated.

Referring to Figure 21, we have a special interest in Subchannel No. 1, the subchannel bounded by the corner rod and the channel corner. Our interest in this particular subchannel stems from the fact that the $\mathrm{CHF}$ condition always occurs on the side of the rod facing this subchannel, as noted earlier. Subchannel No. 1 may be likened to a 90 -degree sector of an internally-heated annulus. If the average conditions in Subchannel No. 1 could be calculated from a knowledge of channel geometry, inlet conditions, and heat flux, then the $\overline{\mathrm{CH}} \overline{\mathrm{F}}$ could be predicted using a $\mathrm{CH} \mathbf{F}$ correlation for internally-heated annuli.

A number of codes suitable for predicting subchannel conditions in multirod arrays now exist: the Westinghouse THINC II** and the Battelle Northwest COBRA ${ }^{(10)}$ in this country; the SASS code, ${ }^{(11)}$ Chalk River, Canada; and the HAMBO code ${ }^{(12)}$ of the U.K. Atomic Energy Establishment, Winfrith, England. Other

* If two of the subchannels are treated as a single subchannel, then the total number of subchannels considered in the analysis is reduced to two.

** This code is proprietary at the present time. Very little information is available in the open literature. codes of this same general type are under development at various laboratories.

We will consider in some detail two of these codes, the COBRA* and the HAMBO.* Each code solves the steady-state version of the continuity, energy, and momentum equations for each of the subchannels considered in the analysis. The analytical model for each is based on the following assumptions.

a. Steady one-dimensional, two-phase slip flow exists in each subchannel during boiling.

b. A static pressure difference can exist between adjacent subchannels. This is the driving potential for crossflow.

c. Crossflow consists of the same average mixture of liquid and vapor that exists in the subchannel from which the crossflow originates.

d. Turbulent mixing takes place between adjacent subchannels. There can be a direct transter of enthalpy but not of mass as a result of this mixing.

The HAMBO code accounts for subcooled voids; the COBRA code assumes subcooled boiling effects are negligible. The COBRA code takes into account changes in saturated liquid and vapor properties with pressure drop along the channel; the HAMBO assumes the effect of pressure drop on properties can be neglected.

* These codes are continually being improved by their developers. This discussion applies to the codes as they existed at the beginning of 1967. Some of the remarks may not apply to the current versions. 


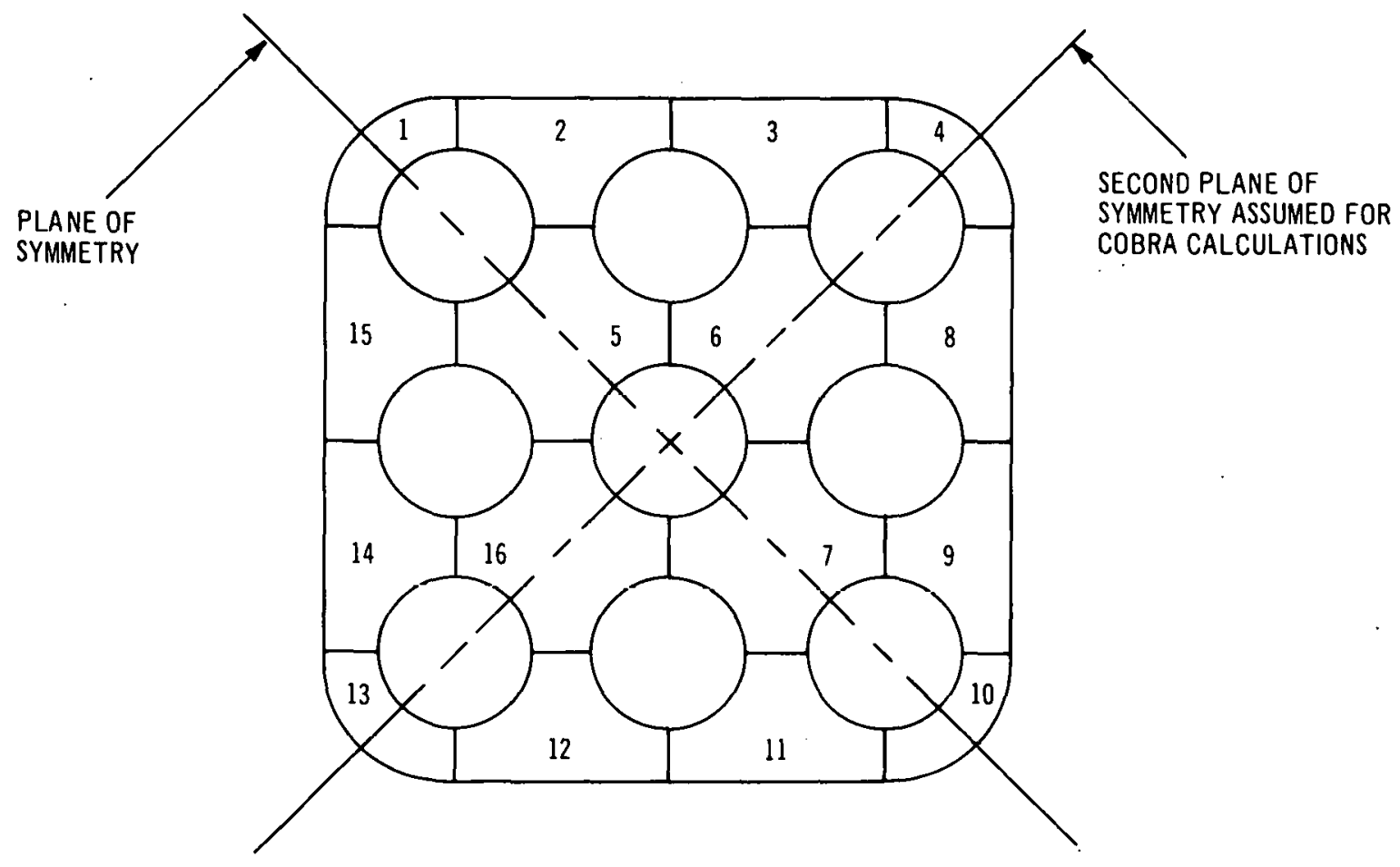

FIGURE 21. DIVISION OF NINE-ROD CHANNEL INTO SUBCHANNELS, AND SUBCHANNEL NUMBERING SCHEME

The following equations apply to subchannel $i$, with $j$ being the index for any particular one of the subchannels adjacent to $i$ and in communication with it. In summing the contributions of the adjacent subchannels, it. does not matter whether the summation is taken over all of the subchannels or just the adjacent ones. The contribution of the nonadjacent subchannels is zero.

\section{CONTINUITY*}

COBRA :

$\frac{\mathrm{dm}_{\mathrm{i}}}{\mathrm{dz}}=-\sum_{\mathrm{j}=1}^{\mathrm{N}} \mathrm{w}_{\mathrm{ij}}, \quad \mathrm{N}=\begin{array}{r}\text { Total number } \\ \text { of subchanncls. }\end{array}$

* The notation and general format of this and the following equations are the same as used in Reference (10), except that $z$ is used in place of $x$ as the axial coordinate, and only vertical channels are considered.
HAMBO :

(Same)

\section{ENERGY}

COBRA :

$$
\begin{aligned}
\frac{d\left(m_{i} h_{i}\right)}{d z}= & q_{i}^{\prime}+\sum_{j=1}^{N} w_{i j}^{\prime}\left(h_{j}-h_{i}\right) \\
& -\sum_{j=1}^{N}\left[\begin{array}{l}
w_{i j} h_{i} ; w_{i j} \geq 0 \\
w_{i j} h_{j} ; w_{i j}<0
\end{array}\right] .
\end{aligned}
$$

HAMBO :

(Same) 


\section{AXIAL MOMENTUM}

COBRA :

$$
\begin{aligned}
& -\frac{d p_{i}}{d z}=\rho_{i}+\frac{1}{g_{c}}\left(\frac{m_{i}}{A_{i}}\right)^{2}\left(\frac{f_{i} \phi_{i}}{2 \rho_{f} D_{i}}\right) \\
& +\frac{1}{g_{c}}\left(\frac{m_{i}}{A_{i}}\right)^{2}\left(\frac{\partial v_{i}^{\prime}}{\partial h} \frac{d h_{i}}{d z}+\frac{\partial v_{i}^{\prime}}{\partial p} \frac{d p_{i}}{d z}\right) \\
& +\frac{1}{g_{c} A_{i}} \sum_{j=1}^{N} f_{T} w_{i j}{ }^{\prime}\left(u_{i}-u_{j}\right) \\
& +\frac{1}{g_{c} A_{1}} \sum_{j=1}^{N}\left[\begin{array}{ll}
w_{i j}\left(f D_{i}^{u_{i}}-2 u_{i}\right) ; w_{i j} \geq 0 \\
w_{i j}\left(f_{D} D_{j}-2 u_{i}\right) ; w_{i j}<0
\end{array}\right],
\end{aligned}
$$

where:

$$
\begin{aligned}
& u_{i}=\frac{m_{i} v_{i}^{\prime}}{A_{i}} \text {, and } \\
& v_{i}^{\prime}=\frac{x_{i}^{2}}{\alpha_{i}} v_{g}+\frac{\left(1-x_{i}\right)^{2}}{1-\alpha_{i}} v_{f} .
\end{aligned}
$$

The two-phase multiplier $\phi_{i}$ and the void fraction $\alpha_{i}$ are due to Armand. (13).

HAMBO :

(Same except $\frac{\partial v_{i}^{\prime}}{\partial p}=0$ and $f_{D}=1$. The third term in the right of equation 13, i.e., the acceleration term, is replaced by its equivalent in terms of slip and quality, viz. ,

$$
\begin{aligned}
-\frac{d n_{a}}{d z}= & \frac{1}{g_{c}}\left(\frac{m_{i}}{A_{i}}\right)^{2} \frac{d}{d z}\left[\frac{1}{\rho_{i}}\left\{1-\frac{\left(S_{i}-1\right)}{s_{i}} x_{i}\right\}\right. \\
& \left.\left\{1+\left(S_{i}-1\right) x_{i}\right)\right]
\end{aligned}
$$

where

$$
\frac{1}{\rho_{\mathrm{i}}}=\mathrm{v}_{\mathrm{i}}=\frac{\mathrm{v}_{\mathrm{f}}}{\alpha_{\mathrm{i}} \frac{\mathrm{v}_{\mathrm{f}}}{\mathrm{v}_{\mathrm{g}}}+\left(1-\alpha_{\mathrm{i}}\right)} .
$$

The two-phase multiplier is given by

$$
\phi_{\mathrm{i}}=1+34 \mathrm{x}_{\mathrm{i}}
$$

derived by the people at Winfrith from analysis of some cluster experimental data. It is close to, but slightly below, the MartinelliNelson two-phase multiplier ${ }^{(14)}$ over most of the quality range of interest.

The calculation of the void fraction $\alpha_{i}$ is based on a constant value for the slip ratio $S_{i}=1.6$. )

\section{TRANSVERSE MOMENTUM}

COBRA :

$p_{i}-p_{j}=c_{i j} w_{i j}\left|w_{i j}\right|$.

HAMBO:

(Same except that a two-phase multiplier is included.)

\section{TURBULENT CROSSFLOW}

COBRA:

$w_{i j}^{\prime}=\frac{1}{2} \beta S_{i j}\left(\frac{m_{i}}{A_{i}}+\frac{m_{j}}{A_{j}}\right)$.

HAMBO :

$$
w_{i j}^{\prime}=\left[\begin{array}{l}
0 ; w_{i j}>4 w_{i j}^{\prime \prime} \\
w_{i j}^{\prime \prime}\left\{1-\frac{w_{i j}}{2 w_{i j}^{\prime \prime}}+\left(\frac{w_{i j}}{4 w_{i j}{ }^{\prime \prime}}\right)^{2}\right\} ; w_{i j} \leq 4 w_{i j}^{\prime \prime}
\end{array}\right],
$$

* We are indebted to Mr. Bob Bowring of Winfrith for information concerning these two relationships in private communciation April 25, 1968. We understand more information will be given in the forthcoming Winf rith report AEEW-R582. 
where:

$$
\begin{gathered}
w_{i j}{ }^{\prime \prime}=F_{m} \frac{N_{i j} \gamma_{i j}}{\left(S_{m}\right)_{i j} d_{i j}} \frac{\sqrt{f_{i}+f_{j}}}{80} \\
\left(D_{i} \frac{m_{i}}{A_{i}}+D_{j} \frac{m_{j}}{A_{j}}\right),
\end{gathered}
$$

and

$$
\begin{array}{ll}
N_{i j} & =\text { Number of rod gaps between } i \text { and } j, \\
\gamma_{i j} & =\begin{array}{l}
\text { Minimum rod gap between } i \text { and } j \\
\text { (feet), }
\end{array} \\
d_{i j} & =\text { Diameter of rods forming gap (feet), } \\
\left(S_{m}\right)_{i j} & =\text { Shape factor for gap geometry, } \\
f_{i} & =\begin{array}{l}
\text { Single phase friction factor in sub- } \\
\text { channel } i \text {, and }
\end{array} \\
D_{i} & =\begin{array}{l}
\text { Equivalent wetted diameter in sub- } \\
\text { channel } i \text { (feet). }
\end{array}
\end{array}
$$

In practice the foregoing equations are solved numerically by taking discrete steps in the independent variable $z$. The equations are solved for all the subchannels at the end of each step by an iterative procedure, thus determining the initial conditions for the next step, etc.

\section{Arrangements were made with}

Mr. D.S. Rowe of Batelle Northwest to calculate, using the COBRA code, the conditions in Subchannel No. 1 corresponding to six different CHF data points obtained with the first nine-rod channel. Subsequently arrangements were also made with Mr. R.W. Bowring of the U.K. Atomic Energy Establishment, Winfrith, to perform calculations using the HAMBO code corresponding to the same six CHF data points.

Table 3 is a list of the six CHF conditions, all for steam-water at 1000 psia, flow upward. The pertinent channel dimensions are given in Figure 22. It should be noted that one corner rod is $10 \%$ higher in heat flux than the average. Both the average heat flux $\bar{\phi}$ and the hot corner rod heat flux $\phi_{1}$ are listed in Table 3. The data have been "adjusted" to correspond to a hot rod which is always $10 \%$ above the average. Actually, the heat flux varied from $3 \%$ to $15 \%$ above the average, depending on the particular set of rods. Even when the hot rod is exactly $10 \%$ above the average, the other rods may be from zero to $5 \%$ below the average, depending on which electrical phase they are in. It is felt that more detailed consideration of these variations in heat flux is not justified at this time. Therefore, one rod has been treated as having 1.1000 times the average power and the remaining eight rods have been treated as though each has 0.9875 times the average power.

Table 4 is a list of the channel exit conditions calculated with the COBRA code, for Subchannels Nos. 1 through 6, all six $\mathrm{CHF}$ conditions, and for the three values for the COBRA turbulent mixing parameter $\beta=0$, $\beta=0.02$, and $\beta=0.05$. The subchannel numbering scheme used for the calculations is shown in Figure 21. A six subchannel approximation was used for the COBRA calculations by assuming the diagonal plane of symmetry as indicated in Figure 21, it having been established that the effect on the results would be negligible. ${ }^{(15)}$ Table 5 is a list of the exit conditions for the same subchannels but calculated with the HAMBO code for three values of the HAMBO mixing parameter: $F_{m}=0, F_{m}=5$, and $F_{m}=10$. All ten subchannels were involved in this calculation, but only the results for subchannel 1 through 6 are listed.

It is shown by a comparison of Tables 4 and 5 that for Subchannel No. 1, the HAMBO code gives generally lower values for subchannel flow and higher values for exit enthalpy (exit quality). The results of the calculations for Subchannel No. 1 are shown graphically in Figures 23 and 24 (COBRA) and Figures 25 and 26 (HAMBO). 
The two graphs for each code correspond to the two values of mass velocity used in the tests. Each graph is a plot of the heat flux for the hot rod versus the Subchannel No. 1 exit quality. It will be noted that there are three points at each value of heat flux corresponding to the three values for the mixing parameter.

Two internally-heated annulus correlations were used, the modified CollierHewitt, ${ }^{(16)}$ and one from GEAP-3899. ${ }^{(3)}$ Each correlation is flow dependent. Each code gives a different value of flow for Subchannel No. 1 for each of the three assigned values of its mixing parameter. Hence, for each correlation there are three correlating lines at each $\mathrm{CHF}$ condition. The correlating lines are superposed on the graphs of Figures 23 through 26.

Referring to Figures 23 and 24 (COBRA results), there is a consistently wide disparity between the point for $\beta=0$ and both of the correlations based on the corresponding Subchannel No. 1 exit conditions. Referring to Figures 25 and 26 (HAMBO results), there is similarly a wide disparity between the point for $F_{m}=0$ and both correlations. Although the two models give somewhat different values for the Subchannel No. 1 exit conditions, the difference is small compared with the disparity noted above. It is evident that a model based on zero turbulent mixing is not satisfactory.

Referring again to Figures 23 through 26 , the points for $\beta=0.02$ and $\beta=0.05$ (COBRA medium and high mixing, respectively) are in surprisingly good agreement with each other. Similarly, the points for $F_{m}=5$ and $F_{m}=10$ (HAMBO medium and high mixing) are in good agreement with each other. Results for medium and high values of the mixing parameter indicate that, at least for a relatively open square lattice such as the nine-rod array used for the Task B tests, the conditions in Subchannel No. 1 are not very sensitive to the amount of mixing as long as it is above some minimum. This may not apply to lattices with different rod-to-rod clearances, i.e., results may be more sensitive to the mixing parameter than indicated here.

The modified Collier-Hewitt correlation is in relatively good agreement with both the $\beta=0.02$ and $\beta=0.05$ points in Figures 23 and 24 , and the $F_{m}=5$ and the $F_{m}=10$ points on Figures 25 and 26 , but tends to give slightly lower values for the $\mathrm{CHF}$ than were measured in the nine-rod tests. The GEAP-3899 correlation is in poor agreement with the points at the lower flow condition $\left(\vec{G}=0.5 \times 10^{6}\right.$ $\mathrm{lb} / \mathrm{h}-\mathrm{ft}^{2}$, Figures 23 and 25), but is in good agreement at the higher flow ( $\overline{\mathrm{G}}=1.0 \times 10^{6}$ $\mathrm{lb} / \mathrm{h}^{-\mathrm{ft}^{2}}{ }^{2}$, Figures 24 and 26). The probable reason for the poor showing of the GEAP3899 correlation at the lower flow is that very few of the data upon which it is based were obtained at flows as low as the calculated flow for Subchannel No. 1.

Although the last few paragraphs above point out strong similarities between the COBRA and HAMBO results, there is no disputing the fact that the COBRA and HAMBO codes give different values for the Subchannel No. 1 exit conditions, as was noted earlier. The models used for turbulent crossflow are different for the two codes, but even when the turbulent crossflow is set to zero, the two codes give different values. Both References (10) and (12) report that relatively large variations in the resistance to crossflow (represented by the coefficient $c_{i j}$ in the transverse momentum equation) cause very little change in exit conditions. It is pointed out in Reference (10) that the COBRA results are not sensitive to the crossflow momentum parameter $f_{D}$, for $0 \leq \mathrm{f}_{\mathrm{D}} \leq 1.0$. 
From the process of elimination of the preceding paragraph it is concluded that the difference between the COBRA and HAMBO results must be due to: a.) subcooled voids, accounted for in HAMBO but not in COBRA, or b.) the use of the Equation (17) two-phase multiplier in HAMBO versus the Armand multiplier in COBRA (the latter being the smaller of the two).

To ascertain more definitely the reason for the difference between the COBRA and the HAMBO results, the COBRA calculations were repeated using the same expression for $\phi_{1}$ as used in the HAMBO calculations, i.e., the twophase multiplier given by Equation (17). The results are listed in Table 6 . The agreement with the HAMBO results is greatly improved. Presumably if the Armand multiplier had been used in both codes rather than Equation (17), the agreement would have been equally good. The results for the two codes correspond to conditions which are generally well into the quality region. If the conditions were near zero quality a big difference in the results would be expected* due to the relatively greater influence of subcooled voids, accounted for in HAMBO but not in COBRA. It is concluded that the difference between the first COBRA results and the HAMBO results is due primarily to the difference in two-phase multiplier. At near zero quality conditions a difference may also be expected due to the presence of subcooled voids model in HAMBO but not in COBRA.

Though there are differences between the COBRA and HAMBO results, the differences are not large, and can, for the most part, be accounted for. Moreover, either code, in combination with the modified Collier-Hewitt correlation for example, will do a pretty fair job of predicting the occurrence of $\mathrm{CHF}$. Bowring ${ }^{(17)}$ has applied Barnett's annulus correlation ${ }^{(4)}$ to the HAMBO results with some success. The use of a multisubchannel computer code in combination with a goodannulus correlation appears to be a promising procedure for predicting $\mathrm{CHF}$ in a multirod channel with rods in a square array.

* This was pointed out by Bowring in private communications April 25, 1968. He ran a test case from Reference 10, using the HAMBO code both with and without the subcooled void model.

TABLE 3

SIX NINE-ROD CRITICAL HEAT FLUX CONDITIONS

\begin{tabular}{|c|c|c|c|c|c|c|c|c|}
\hline un No. & $\begin{array}{l}\text { Heated } \\
\text { Length } \\
\text { (inches) }\end{array}$ & $\begin{array}{c}\mathrm{W} \\
(\mathrm{lb} / \mathrm{sec})\end{array}$ & $\begin{array}{c}\Delta \mathrm{h}_{\mathrm{S}} \\
(\mathrm{Btu} / \mathrm{lb}) \\
\end{array}$ & $\begin{array}{c}\text { Power } \\
(\mathrm{kW})\end{array}$ & $\begin{array}{c}\bar{G} / 10^{6} \\
\left(1 \mathrm{~b} / \mathrm{h}-\mathrm{ft}^{2}\right)\end{array}$ & $\begin{array}{c}\bar{\phi} / 10^{6} \\
\left(\mathrm{Btu} / \mathrm{h}-\mathrm{ft}^{2}\right) \\
\end{array}$ & $\begin{array}{c}\phi / 10^{6} \\
\left(\mathrm{Btu} / \mathrm{h}-\mathrm{ft}^{2}\right) \\
\end{array}$ & $\mathrm{x}_{\mathrm{e}}$ \\
\hline 77 & 30 & 2.25 & 90.5 & $4 G C$ & 0.491 & 0.618 & 0.680 & 0.256 \\
\hline 85 & 30 & 2.25 & 160.0 & 622 & 0.491 & 0.824 & 0.906 & 0.158 \\
\hline 211 & 60 & 2.25 & 97.5 & $7 G 3$ & 0.491 & 0.505 & 0.555 & 0.345 \\
\hline 269 & 30 & 4.66 & 124.0 & 788 & 1.018 & 1.042 & 1. 148 & 0.056 \\
\hline 419 & 60 & 4.69 & 23.5 & 911 & 1.023 & 0.603 & 0.663 & 0.248 \\
\hline 422 & 60 & 4.69 & 158.5 & 1293 & 1.023 & 0.855 & 0.940 & 0.159 \\
\hline
\end{tabular}




$$
\text { GEAP }-5616
$$
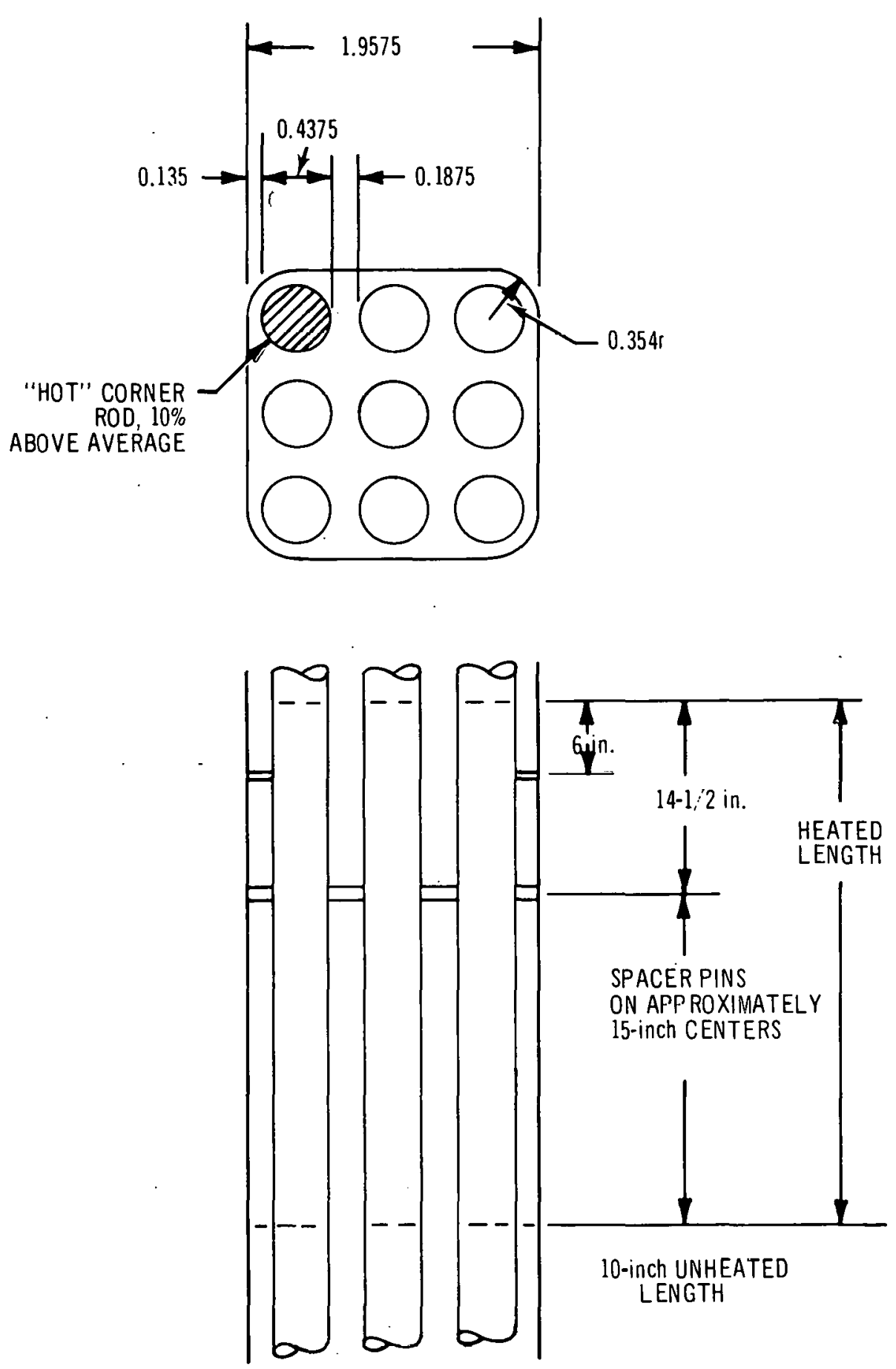

NOTE: ALL DIMENSIONS ARE IN INCHES. 
TABLE 4

SUBCHANNEL EXIT CONDITIONS CALCULATED WITH COBRA CODE USING ARMAND TWO-PHASE MULTIPLIER

\begin{tabular}{|c|c|c|c|c|c|c|c|c|c|c|c|c|c|}
\hline \multirow[b]{3}{*}{ Run No. } & \multirow[b]{3}{*}{$\beta$} & \multicolumn{12}{|c|}{ Subchannel Number } \\
\hline & & \multicolumn{2}{|c|}{1} & \multicolumn{2}{|c|}{2} & \multicolumn{2}{|c|}{3} & \multicolumn{2}{|c|}{4} & \multicolumn{2}{|c|}{5} & \multicolumn{2}{|c|}{6} \\
\hline & & $\mathrm{h}$ & $\underline{G} / 10^{6}$ & $\mathbf{h}$ & $\mathrm{G} / 10^{6}$ & $\mathrm{~h}$ & $\underline{G} / 10^{6}$ & $\mathrm{~h}$ & $\mathrm{G} / 10^{6}$ & $\mathrm{~h}$ & $\mathrm{G} / 10^{6}$ & $\mathrm{~h}$ & $\underline{G} / 10^{6}$ \\
\hline 77 & $\left\{\begin{array}{l}0.05 \\
0.02 \\
0\end{array}\right.$ & $\begin{array}{l}720.7 \\
734.5 \\
827.0\end{array}$ & $\begin{array}{l}0.391 \\
0.381 \\
0.311\end{array}$ & $\begin{array}{l}711.9 \\
712 . \mathrm{g} \\
707.7\end{array}$ & $\begin{array}{l}0.478 \\
0.477 \\
0.484\end{array}$ & $\begin{array}{l}708.1 \\
705.1 \\
695.5\end{array}$ & $\begin{array}{l}0.480 \\
0.484 \\
0.498\end{array}$ & $\begin{array}{l}713.8 \\
719.6 \\
785.0\end{array}$ & $\begin{array}{l}0.396 \\
0.396 \\
0.338\end{array}$ & $\begin{array}{l}712.9 \\
714.0 \\
710.7\end{array}$ & $\begin{array}{l}0.529 \\
0.528 \\
0.530\end{array}$ & $\begin{array}{l}710.2 \\
707.9 \\
704.8\end{array}$ & $\begin{array}{l}0.531 \\
0.533 \\
0.537\end{array}$ \\
\hline 85 & $\left\{\begin{array}{l}0.05 \\
0.02 \\
0\end{array}\right.$ & $\begin{array}{l}657.6 \\
677.5 \\
771.9\end{array}$ & $\begin{array}{l}0.439 \\
0.430 \\
0.335\end{array}$ & $\begin{array}{l}6 \leq 8.6 \\
652.7 \\
6 \leq 9.5\end{array}$ & $\begin{array}{l}0.493 \\
0.491 \\
0.498\end{array}$ & $\begin{array}{l}645.2 \\
646.5 \\
634.4\end{array}$ & $\begin{array}{l}0.491 \\
0.488 \\
0.507\end{array}$ & $\begin{array}{l}650.9 \\
663.2 \\
737.9\end{array}$ & $\begin{array}{l}0.441 \\
0.438 \\
0.374\end{array}$ & $\begin{array}{l}649.4 \\
643.1 \\
637.4\end{array}$ & $\begin{array}{r}505 \\
512 \\
18\end{array}$ & $\begin{array}{l}647.6 \\
640.6 \\
633.8\end{array}$ & $\begin{array}{l}0.500 \\
0.503 \\
0.506\end{array}$ \\
\hline 211 & $\left\{\begin{array}{l}0.05 \\
0.02 \\
0\end{array}\right.$ & $\begin{array}{l}7.30 .3 \\
734.5 \\
9.31 .5\end{array}$ & $\begin{array}{l}0.372 \\
0.364 \\
0.275\end{array}$ & $\begin{array}{l}7: 2.0 \\
773.5 \\
767.6\end{array}$ & $\begin{array}{l}0.471 \\
0.471 \\
0.476\end{array}$ & $\begin{array}{l}769.0 \\
766.4 \\
746.9\end{array}$ & $\begin{array}{l}0.473 \\
0.476 \\
0.497\end{array}$ & $\begin{array}{l}774.7 \\
780.7 \\
902.9\end{array}$ & $\begin{array}{l}0.375 \\
0.367 \\
0.301\end{array}$ & $\begin{array}{l}770.8 \\
770.8 \\
766.7\end{array}$ & $\begin{array}{l}0 . \\
0 . \\
0 .\end{array}$ & $\begin{array}{l}768.9 \\
766.7 \\
759.3\end{array}$ & $\begin{array}{l}0.545 \\
0.545 \\
0.551\end{array}$ \\
\hline 269 & $\left\{\begin{array}{l}0.05 \\
0.02 \\
0\end{array}\right.$ & $\begin{array}{l}5 \exists 3.7 \\
610.8 \\
7: 1.5\end{array}$ & $\begin{array}{l}0.859 \\
0.822 \\
0.542\end{array}$ & $\begin{array}{l}585.4 \\
588.9 \\
588.3\end{array}$ & $\begin{array}{l}0.959 \\
0.952 \\
0.919\end{array}$ & $\begin{array}{l}581.3 \\
582.3 \\
578.0\end{array}$ & $\begin{array}{l}0.988 \\
0.977 \\
0.951\end{array}$ & $\begin{array}{l}586.9 \\
598.3 \\
680.5\end{array}$ & $\begin{array}{l}0.878 \\
0.850 \\
0.629\end{array}$ & $\begin{array}{l}577.5 \\
572.3 \\
565.7\end{array}$ & $\begin{array}{l}1.077 \\
1.136 \\
1.188\end{array}$ & $\begin{array}{l}573.9 \\
569.3 \\
560.0\end{array}$ & $\begin{array}{l}1.142 \\
1.122 \\
1.268\end{array}$ \\
\hline 419 & $\left\{\begin{array}{l}0.05 \\
0.02 \\
0\end{array}\right.$ & $\begin{array}{l}711.7 \\
721.1 \\
834.4\end{array}$ & $\begin{array}{l}0.761 \\
0.744 \\
0.541\end{array}$ & $\begin{array}{l}706.7 \\
708.3 \\
704.7\end{array}$ & $\begin{array}{l}0.976 \\
0.972 \\
0.982\end{array}$ & $\begin{array}{l}705.0 \\
703.8 \\
690.6\end{array}$ & $\begin{array}{l}0.980 \\
0.983 \\
1.024\end{array}$ & $\begin{array}{l}708.5 \\
712.6 \\
810.1\end{array}$ & $\begin{array}{l}0.768 \\
0.761 \\
0.599\end{array}$ & $\begin{array}{l}705.2 \\
704.8 \\
701.4\end{array}$ & $\begin{array}{l}1.142 \\
1.143 \\
1.151\end{array}$ & $\begin{array}{l}704.1 \\
702.0 \\
694.7\end{array}$ & $\begin{array}{l}1.144 \\
1.150 \\
1.173\end{array}$ \\
\hline 422 & $\left\{\begin{array}{l}0.05 \\
0.02 \\
0\end{array}\right.$ & $\begin{array}{l}655.7 \\
670.9 \\
948.8\end{array}$ & $\begin{array}{l}0.834 \\
0.805 \\
0.447\end{array}$ & $\begin{array}{l}649.8 \\
654.5 \\
658.4\end{array}$ & $\begin{array}{l}0.999 \\
0.993 \\
0.986\end{array}$ & $\begin{array}{l}646.9 \\
647.8 \\
638.5\end{array}$ & $\begin{array}{l}1.005 \\
1.008 \\
1.041\end{array}$ & $\begin{array}{l}650.6 \\
658.5 \\
829.9\end{array}$ & $\begin{array}{l}0.845 \\
0.835 \\
0.542\end{array}$ & $\begin{array}{l}649.3 \\
645.4 \\
629.0\end{array}$ & $\begin{array}{l}1.090 \\
1.096 \\
1.156\end{array}$ & $\begin{array}{l}647.1 \\
640.5 \\
619.2\end{array}$ & $\begin{array}{l}1.099 \\
1.109 \\
1.180\end{array}$ \\
\hline
\end{tabular}

$\mathrm{h}=$ Enthalpy, Btu/lb.

$\mathbf{G}=$ Mass velocity, $\mathrm{Ib} / \mathrm{h}-\mathrm{ft}^{2}$.

$\hat{\beta}=$ Turbulent intensity, dimensionless. 
TABLE 5

SUBCHANNEL EXIT CONDITIONS CALCULATED WITH HAMBO CODE

USING TWO-PHASE MULTIPLIER $\phi=1+34 \times$

\begin{tabular}{|c|c|c|c|c|c|c|c|c|c|c|c|c|c|}
\hline \multirow[b]{3}{*}{ Run No. } & \multirow[b]{3}{*}{$\mathrm{F}_{\mathrm{m}}$} & \multicolumn{12}{|c|}{ Subchannel No. } \\
\hline & & \multicolumn{2}{|c|}{1} & \multicolumn{2}{|c|}{2} & \multicolumn{2}{|c|}{3} & \multicolumn{2}{|c|}{4} & \multicolumn{2}{|c|}{5} & \multicolumn{2}{|c|}{6} \\
\hline & & $\mathrm{h}$ & $\mathrm{G} / 10^{6}$ & $\mathrm{~h}$ & $\mathrm{G} / 10^{6}$ & $\mathrm{~h}$ & $\underline{G} / 10^{6}$ & $\mathrm{~h}$ & $\mathrm{G} / 10^{6}$ & $\mathrm{~h}$ & $\mathrm{G} / 10^{6}$ & $\mathrm{~h}$ & $\underline{G} / 10^{6}$ \\
\hline 77 & $\left\{\begin{array}{r}10 \\
5 \\
0\end{array}\right.$ & $\begin{array}{l}731.8 \\
754.7 \\
876.7\end{array}$ & $\begin{array}{l}0.384 \\
0.353 \\
0.279\end{array}$ & $\begin{array}{l}712.1 \\
712.5 \\
712.6\end{array}$ & $\begin{array}{l}0.476 \\
0.474 \\
0.466\end{array}$ & $\begin{array}{l}706.1 \\
703.5 \\
697.8\end{array}$ & $\begin{array}{l}0.484 \\
0.485 \\
0.482\end{array}$ & $\begin{array}{l}717.7 \\
732.0 \\
822.8\end{array}$ & $\begin{array}{l}0.400 \\
0.372 \\
0.303\end{array}$ & $\begin{array}{l}712.0 \\
712.2 \\
704.7\end{array}$ & $\begin{array}{l}20 \\
27 \\
50\end{array}$ & $\begin{array}{l}708.5 \\
707.3 \\
697.7\end{array}$ & $\begin{array}{l}0.525 \\
0.534 \\
0.559\end{array}$ \\
\hline 85 & $\left\{\begin{array}{r}10 \\
5 \\
0\end{array}\right.$ & $\begin{array}{l}674.7 \\
704.8 \\
850.5\end{array}$ & $\begin{array}{l}0.376 \\
0.336 \\
0.253\end{array}$ & $\begin{array}{l}648.9 \\
649.4 \\
651.8\end{array}$ & $\begin{array}{l}0.478 \\
0.476 \\
0.471\end{array}$ & $\begin{array}{l}641.7 \\
638.7 \\
633.1\end{array}$ & $\begin{array}{l}0.484 \\
0.484 \\
0.482\end{array}$ & $\begin{array}{l}657.1 \\
675.6 \\
781.6\end{array}$ & $\begin{array}{l}0.398 \\
0.364 \\
0.284\end{array}$ & $\begin{array}{l}648.9 \\
648.8 \\
640.4\end{array}$ & & $\begin{array}{l}644.7 \\
643.1 \\
631.9\end{array}$ & $\begin{array}{l}0.526 \\
0.537 \\
0.562\end{array}$ \\
\hline 211 & $\begin{array}{r}10 \\
5 \\
0\end{array}$ & $\begin{array}{r}789.7 \\
814.3 \\
1082.4\end{array}$ & $\begin{array}{l}0.382 \\
0.348 \\
0.235\end{array}$ & $\begin{array}{l}771.3 \\
774.2 \\
772.6\end{array}$ & $\begin{array}{l}0.473 \\
0.467 \\
0.461\end{array}$ & $\begin{array}{l}765.7 \\
764.2 \\
746.8\end{array}$ & $\begin{array}{l}0.480 \\
0.478 \\
0.485\end{array}$ & $\begin{array}{l}775.7 \\
790.0 \\
980.6\end{array}$ & $\begin{array}{l}0.394 \\
0.365 \\
0.262\end{array}$ & $\begin{array}{l}769.7 \\
769.6 \\
762.9\end{array}$ & & $\begin{array}{l}766.2 \\
763.9 \\
751.7\end{array}$ & $\begin{array}{l}0.531 \\
0.543 \\
0.568\end{array}$ \\
\hline 269 & $\begin{array}{r}10 \\
5 \\
0\end{array}$ & $\begin{array}{l}59 \subseteq .4 \\
62 \Xi .0 \\
77 \Xi .3\end{array}$ & $\begin{array}{l}0.809 \\
0.712 \\
0.443\end{array}$ & $\begin{array}{l}582.3 \\
583.7 \\
594.0\end{array}$ & $\begin{array}{l}0.984 \\
0.971 \\
0.910\end{array}$ & $\begin{array}{l}576.8 \\
575.3 \\
578.1\end{array}$ & $\begin{array}{l}1.004 \\
0.999 \\
0.953\end{array}$ & $\begin{array}{l}586.4 \\
601.3 \\
717.0\end{array}$ & $\begin{array}{l}0.846 \\
0.773 \\
0.505\end{array}$ & $\begin{array}{l}582.0 \\
580.9 \\
565.8\end{array}$ & $\begin{array}{l}1.072 \\
1.098 \\
1.223\end{array}$ & $\begin{array}{l}578.7 \\
576.3 \\
559.8\end{array}$ & $\begin{array}{l}1.085 \\
1.115 \\
1.250\end{array}$ \\
\hline 419 & $\left\{\begin{array}{r}10 \\
5 \\
0\end{array}\right.$ & $\begin{array}{l}71 \in .8 \\
73 \mathfrak{c} .8 \\
91 G .6\end{array}$ & $\begin{array}{l}0.804 \\
0.730 \\
0.482\end{array}$ & $\begin{array}{l}706.3 \\
708.3 \\
711.0\end{array}$ & $\begin{array}{l}0.985 \\
0.972 \\
0.942\end{array}$ & $\begin{array}{l}702.8 \\
701.9 \\
694.8\end{array}$ & $\begin{array}{l}0.998 \\
0.992 \\
0.986\end{array}$ & $\begin{array}{l}708.8 \\
717.6 \\
853.3\end{array}$ & $\begin{array}{l}0.827 \\
0.765 \\
0.534\end{array}$ & $\begin{array}{l}705.3 \\
705.3 \\
696.0\end{array}$ & $\begin{array}{l}1.097 \\
1.119 \\
1.189\end{array}$ & $\begin{array}{l}703.1 \\
701.6 \\
688.8\end{array}$ & $\begin{array}{l}1.106 \\
1.132 \\
1.214\end{array}$ \\
\hline 422 & $\left\{\begin{array}{r}10 \\
5 \\
0\end{array}\right.$ & $\begin{array}{r}665.8 \\
695 \cdot 3 \\
1085.8\end{array}$ & $\begin{array}{l}0.791 \\
0.691 \\
0.343\end{array}$ & $\begin{array}{l}650.3 \\
653.9 \\
672.6\end{array}$ & $\begin{array}{l}0.982 \\
0.964 \\
0.881\end{array}$ & $\begin{array}{l}644.7 \\
643.4 \\
644.0\end{array}$ & $\begin{array}{l}1.008 \\
1.007 \\
0.972\end{array}$ & $\begin{array}{l}652.5 \\
666.3 \\
938.0\end{array}$ & $\begin{array}{l}0.838 \\
0.760 \\
0.408\end{array}$ & $\begin{array}{l}649.2 \\
649.2 \\
625.4\end{array}$ & $\begin{array}{l}1.076 \\
1.095 \\
1.228\end{array}$ & $\begin{array}{l}645.6 \\
643.0 \\
614.0\end{array}$ & $\begin{array}{l}1.093 \\
1.123 \\
1.287\end{array}$ \\
\hline
\end{tabular}

$\begin{array}{ll}\mathrm{h} & =\text { Enthalpy, Btu/lb. } \\ \mathrm{G} & =\text { Mass velo }: \text { ity, } \mathrm{lb} / \mathrm{h}-\mathrm{ft}^{2} .\end{array}$

$\mathbf{F}_{\mathrm{m}}=$ Turbulent mixing factor, dimensionless. 


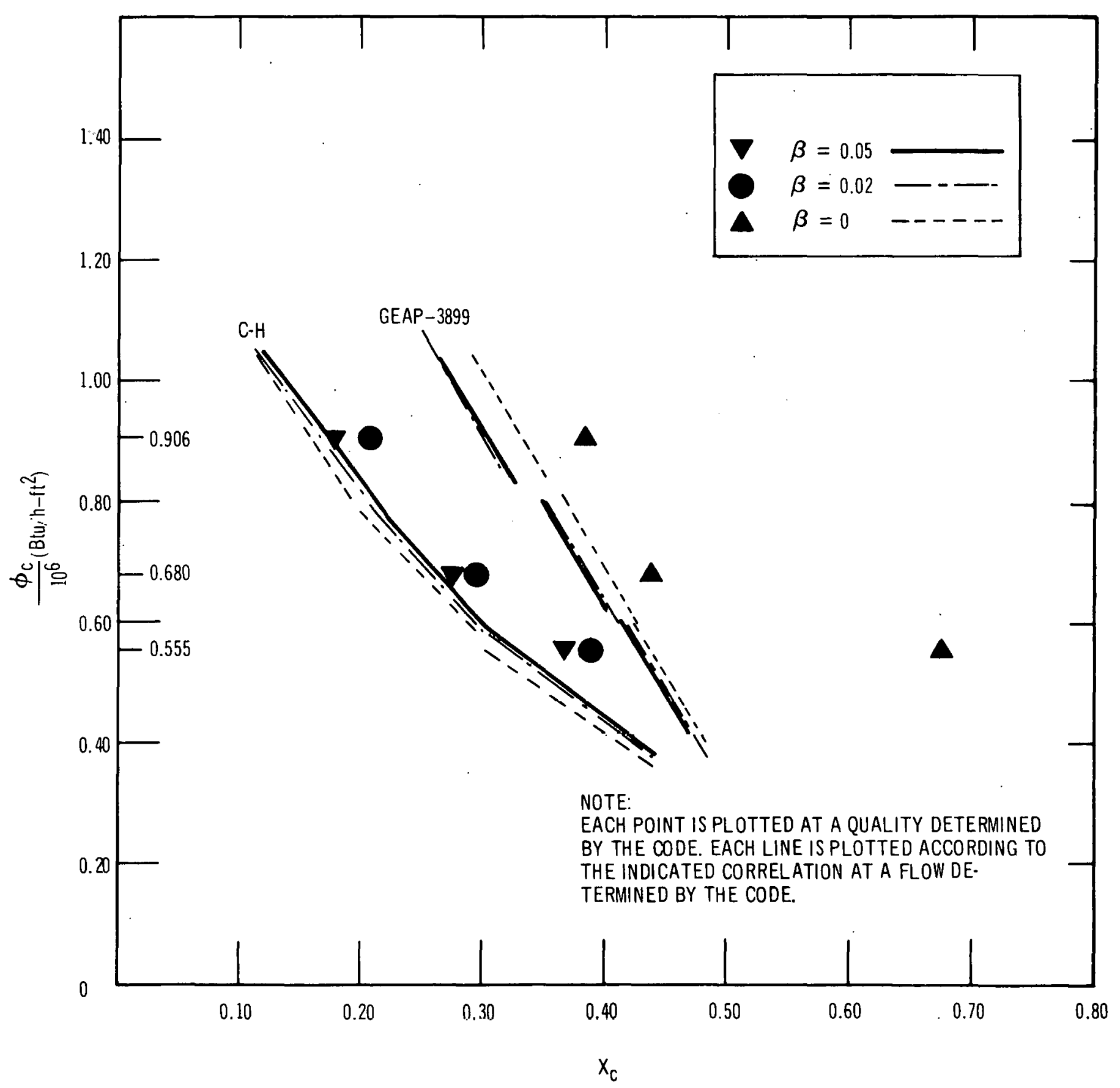

FIGURE 23. CRITICAL HEAT FLUX VERSUS QUALITY CALCULATED BY COBRA FOR SUBCHANNEL NO. 1, AT 1000 psio, $0.5 \times 10^{6} \mathrm{lb} / \mathrm{h}-\mathrm{ft} 2$ 


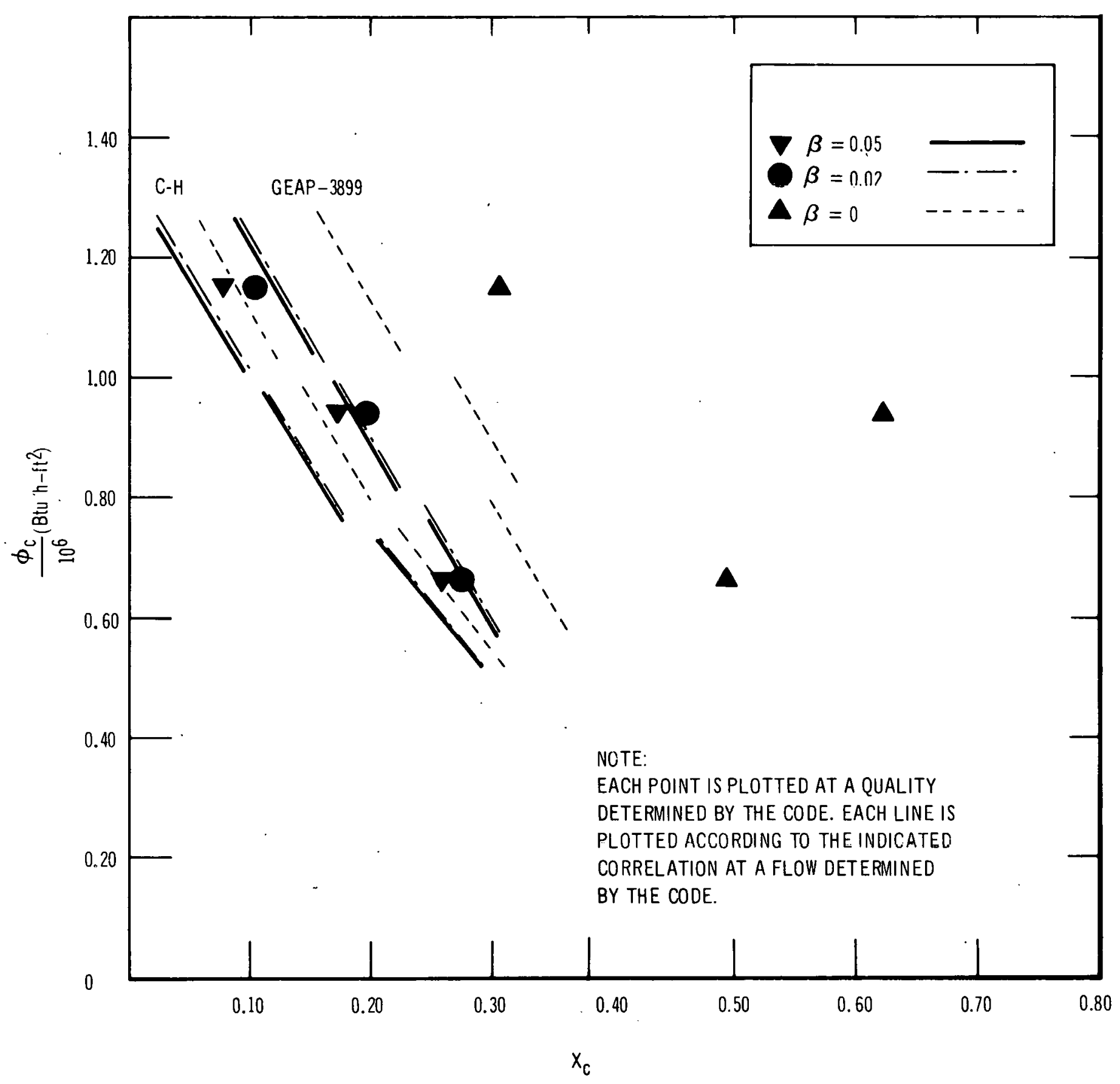

FIGURE 24. CRITICAL HEAT FLUX VERSUS QUALITY CALCULATED BY COBRA FOR SUBCHANNEL NO. 1, AT $1000 \mathrm{psia,} 1.0 \times 10^{6} \mathrm{lb} / \mathrm{h}-\mathrm{ft}^{2}$ 


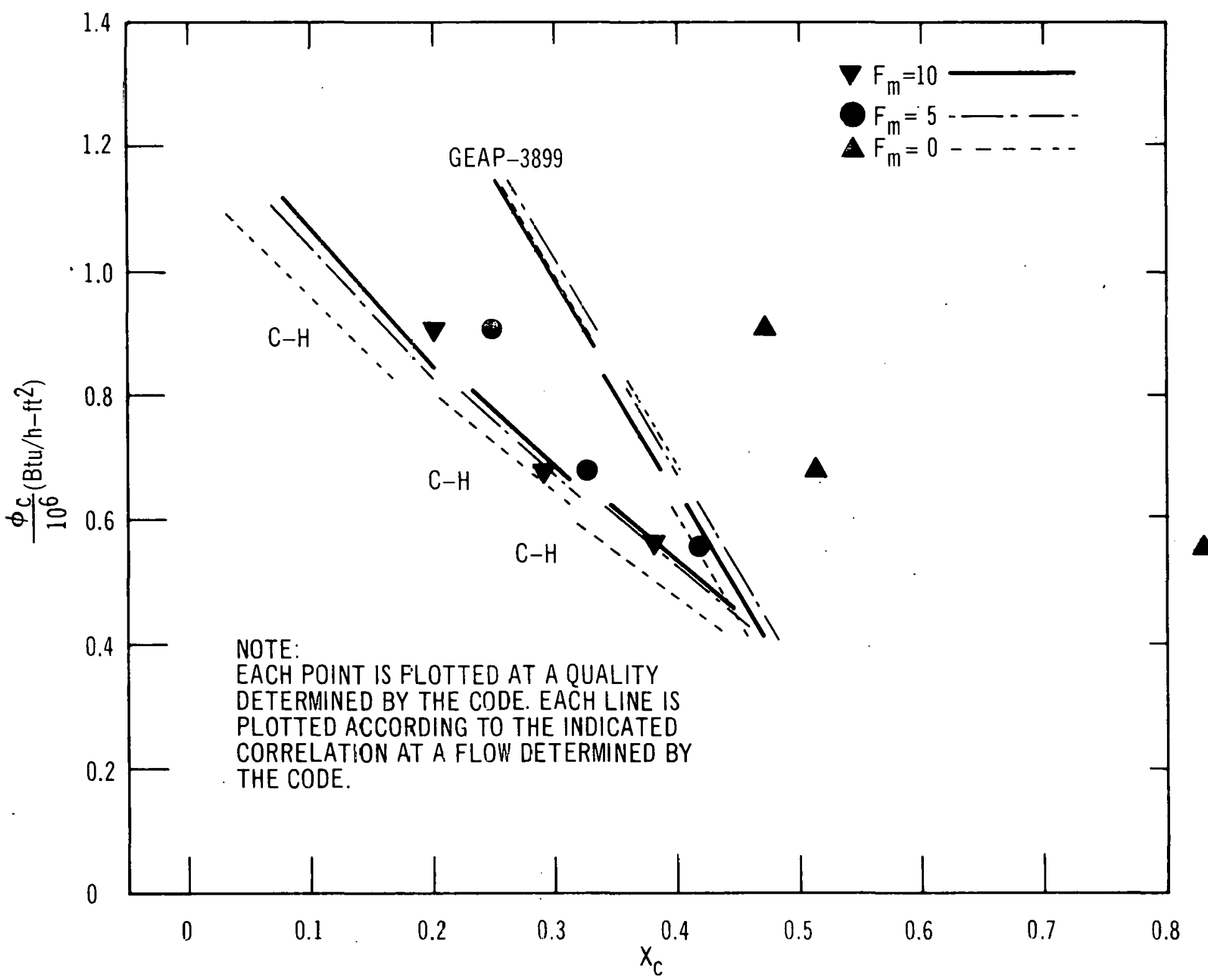

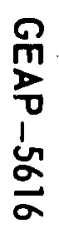

FIGURE 25. CRITICAL HEAT FLUX VERSUS QUALITY CALCULATED BY HAMBO FOR SUBCHANNEL NO. I, AT $1000 \mathrm{psia}, 0.5 \times 10^{6} \mathrm{lb} / \mathrm{h}-\mathrm{ft}^{2}$ 


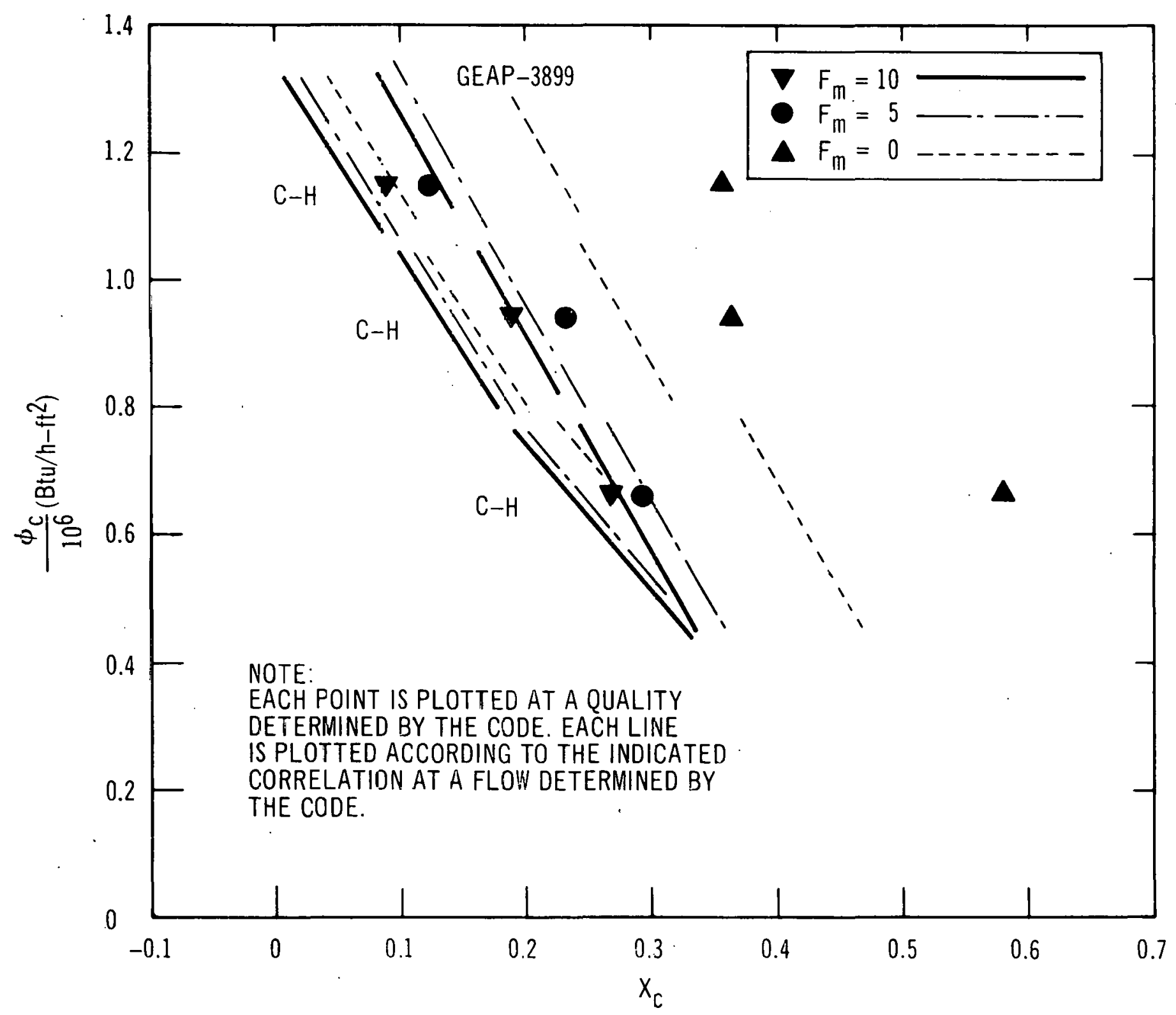

ñ
o
un
a

FIGURE 26. CRITICAL HEAT FLUX VERSUS QUALITY CALCULATED BY HAMBO FOR SUBCHANNEL NO. 1 , AT $1000 \mathrm{psia}, 1.0 \times 10^{6} \mathrm{lb} / \mathrm{h}-\mathrm{ft}_{\mathrm{t}} 2$ 
TABLE 6

SUBCHANNE $\triangle$ EXIT CONDITIONS CALCULATED WITH COBRA CODE USING TWO-PHASE MULTIPLIER $\phi=1+34 \times$

Subchannel No.

\begin{tabular}{|c|c|c|c|c|c|c|c|c|c|c|c|c|c|}
\hline \multirow[b]{3}{*}{ Run No. } & \multirow[b]{3}{*}{$\beta$} & \multicolumn{12}{|c|}{ Subchannel No. } \\
\hline & & \multicolumn{2}{|c|}{1} & \multicolumn{2}{|c|}{2} & \multicolumn{2}{|c|}{3} & \multicolumn{2}{|c|}{4} & \multicolumn{2}{|c|}{5} & \multicolumn{2}{|c|}{6} \\
\hline & & $h$ & $\mathrm{G} / 10^{6}$ & $\mathbf{h}$ & $\mathrm{G} / 10^{6}$ & $\mathrm{~h}$ & $\mathrm{G} / 10^{6}$ & $\mathrm{~h}$ & $\mathrm{G} / 10^{6}$ & $\mathrm{~h}$ & $\mathrm{G} / 10^{6}$ & $\mathrm{~h}$ & $\mathrm{G} / 10^{6}$ \\
\hline 77 & $\begin{array}{l}0.05 \\
0.02 \\
0\end{array}$ & $\begin{array}{l}723.9 \\
742.2 \\
865.7\end{array}$ & $\begin{array}{l}0.367 \\
0.353 \\
0.276\end{array}$ & $\begin{array}{l}713.5 \\
715.8 \\
710.8\end{array}$ & $\begin{array}{l}0.468 \\
0.465 \\
0.471\end{array}$ & $\begin{array}{l}709.5 \\
707.2 \\
696.4\end{array}$ & $\begin{array}{l}0.471 \\
0.474 \\
0.489\end{array}$ & $\begin{array}{l}716.5 \\
725.5 \\
813.6\end{array}$ & $\begin{array}{l}0.372 \\
0.365 \\
0.302\end{array}$ & $\begin{array}{l}710.9 \\
710.4 \\
706.2\end{array}$ & $\begin{array}{r}0.547 \\
0.547 \\
0.550\end{array}$ & $\begin{array}{l}708.3 \\
704.4 \\
699.3\end{array}$ & $\begin{array}{l}0.549 \\
0.553 \\
0.560\end{array}$ \\
\hline 85 & $\begin{array}{l}0.05 \\
0.02 \\
0\end{array}$ & $\begin{array}{l}663.1 \\
689.8 \\
862.8\end{array}$ & $\begin{array}{l}0.396 \\
0.374 \\
0.263\end{array}$ & $\begin{array}{l}651.2 \\
656.6 \\
653.3\end{array}$ & $\begin{array}{l}0.481 \\
0.474 \\
0.480\end{array}$ & $\begin{array}{l}646.8 \\
648.6 \\
635.4\end{array}$ & $\begin{array}{l}0.485 \\
0.482 \\
0.503\end{array}$ & $\begin{array}{l}654.8 \\
671.7 \\
788.2\end{array}$ & $\begin{array}{l}0.404 \\
0.390 \\
0.299\end{array}$ & $\begin{array}{l}647.7 \\
640.7 \\
634.0\end{array}$ & $\begin{array}{l}0.524 \\
0.534 \\
0.542\end{array}$ & $\begin{array}{l}645.3 \\
636.9 \\
628.0\end{array}$ & $\begin{array}{l}0.524 \\
0.534 \\
0.544\end{array}$ \\
\hline 211 & $\begin{array}{l}0.05 \\
0.02 \\
0\end{array}$ & $\begin{array}{r}7 \varepsilon 3.0 \\
8 \mathrm{C} \cdot 1.4 \\
10 \varepsilon 7.0\end{array}$ & $\begin{array}{l}0.353 \\
0.342 \\
0.230\end{array}$ & $\begin{array}{l}773.6 \\
777.3 \\
777.9\end{array}$ & $\begin{array}{l}0.461 \\
0.458 \\
0.457\end{array}$ & $\begin{array}{l}770.6 \\
769.5 \\
749.4\end{array}$ & $\begin{array}{l}0.463 \\
0.464 \\
0.484\end{array}$ & $\begin{array}{l}777.1 \\
786.4 \\
978.2\end{array}$ & $\begin{array}{l}0.356 \\
0.351 \\
0.260\end{array}$ & $\begin{array}{l}769.0 \\
766.9 \\
760.2\end{array}$ & $\begin{array}{l}0.560 \\
0.562 \\
0.567\end{array}$ & $\begin{array}{l}767.1 \\
762.3 \\
741.0\end{array}$ & $\begin{array}{l}0.561 \\
0.566 \\
0.589\end{array}$ \\
\hline 269 & $\begin{array}{l}0.05 \\
0.02 \\
0\end{array}$ & $\begin{array}{l}595.4 \\
616.3 \\
7 \in .9 .8\end{array}$ & $\begin{array}{l}0.788 \\
0.713 \\
0.429\end{array}$ & $\begin{array}{l}5 € 8.2 \\
5 \subseteq 0.3 \\
5 \subseteq 0.0\end{array}$ & $\begin{array}{l}0.819 \\
0.923 \\
0.908\end{array}$ & $\begin{array}{l}581.7 \\
583.0 \\
577.9\end{array}$ & $\begin{array}{l}0.977 \\
0.964 \\
0.971\end{array}$ & $\begin{array}{l}588.2 \\
601.7 \\
709.5\end{array}$ & $\begin{array}{l}0.819 \\
0.764 \\
0.496\end{array}$ & $\begin{array}{l}576.9 \\
571.8 \\
565.3\end{array}$ & $\begin{array}{l}1.112 \\
1.177 \\
1.251\end{array}$ & $\begin{array}{l}573.7 \\
568.6 \\
560.7\end{array}$ & $\begin{array}{l}1.172 \\
1.182 \\
1.257\end{array}$ \\
\hline 419 & $\begin{array}{l}0.05 \\
0.02 \\
0\end{array}$ & $\begin{array}{l}713.3 \\
7 \varepsilon 5.6 \\
912.2\end{array}$ & $\begin{array}{l}0.724 \\
0.701 \\
0.483\end{array}$ & $\begin{array}{l}707.6 \\
710.7 \\
710.1\end{array}$ & $\begin{array}{l}0.957 \\
0.949 \\
0.945\end{array}$ & $\begin{array}{l}705.8 \\
705.9 \\
693.8\end{array}$ & $\begin{array}{l}0.961 \\
0.961 \\
0.994\end{array}$ & $\begin{array}{l}709.9 \\
716.4 \\
846.0\end{array}$ & $\begin{array}{l}0.730 \\
0.718 \\
0.538\end{array}$ & $\begin{array}{l}704.3 \\
702.2 \\
694.9\end{array}$ & $\begin{array}{l}1.174 \\
1.181 \\
1.203\end{array}$ & $\begin{array}{l}703.1 \\
699.3 \\
687.6\end{array}$ & $\begin{array}{l}1.177 \\
1.190 \\
1.232\end{array}$ \\
\hline 422 & $\begin{array}{l}0.05 \\
0.02 \\
0\end{array}$ & $\begin{array}{r}657.9 \\
679.7 \\
1061.7\end{array}$ & $\begin{array}{l}0.768 \\
0.718 \\
0.358\end{array}$ & $\begin{array}{l}650.7 \\
658.4 \\
66.4 .5\end{array}$ & $\begin{array}{l}0.978 \\
0.955 \\
0.921\end{array}$ & $\begin{array}{l}648.1 \\
649.5 \\
640.9\end{array}$ & $\begin{array}{l}0.986 \\
0.984 \\
1.005\end{array}$ & $\begin{array}{l}653.0 \\
663.5 \\
918.3\end{array}$ & $\begin{array}{l}0.780 \\
0.755 \\
0.427\end{array}$ & $\begin{array}{l}647.6 \\
643.2 \\
625.8\end{array}$ & $\begin{array}{l}1.133 \\
1.145 \\
1.214\end{array}$ & $\begin{array}{l}645.9 \\
636.5 \\
612.5\end{array}$ & $\begin{array}{l}1.138 \\
1.176 \\
1.296\end{array}$ \\
\hline
\end{tabular}

$\mathrm{h}=$ Enthalpy, Btu/lb. $/ \mathrm{ft}^{2}$.

$\beta=$ Turbulent intensity, dimensionless. 


\section{CONCLUSIONS}

On the basis of the test results it is concluded that:

1. For rods in a normally-spaced square array the CHF occurs on one of the corner rods.

2. The CHF decreases as the average quality increases, other things being the same. The average quality is the dominant parameter in determining $\mathrm{CHF}$.

3. There is no strong or consistent effect of length on CHF.

4. There is no flow effect on CHF for flows greater than $0.75 \times 10^{6}$ $\mathrm{lb} / \mathrm{h}-\mathrm{ft}^{2}$. For flows less than this the CHF tends to vary in an inverse manner with the flow, but the effect is not strong.

5. In the range of pressures from 600 to $1400 \mathrm{psia}$, the CHF varies in an inverse manner with the pressure, other things being the same.
6. A reduction in rod-to-wall clearance from 0.135 inch to 0.060 inch causes a $15 \%$ reduction in $\mathrm{CHF}$.

Comparisons of the nine-rod (square array) CHF data reported here with 19rod, 37-rod, and seven-rod (circular array) CHF data reported elsewhere, and with multirod correlations due to Becker and to Barnett (obtained largely with bundles in a circular array) show generally poor agreement, when the comparison is on the basis of the same average exit quality and mass velocity. It is evident that the use of average channel conditions for correlating purposes has significant limitations, in particular for correlating circular array results with square array results.

Multisubchannel computer codes consider channel conditions in more detail, thus providing the means for a possible improvement in the correlation of multirod data. Two such codes, the COBRA and the HAMBO, when used in combination with a simple channel (internally-heated annulus) CHF in the nine-rod channel, give fair to good agreement with measured CHF. The use of such codes appears to be a promising procedure for predicting CHF in a multirod array. 


\section{ACKNOWLEDGMENTS}

The work reported here comprises all of Task B of P.A. 44, Two-Phase Flow and Heat Transfer in Multirod Geometries, sponsored by the U.S. Atomic Energy Commission.

The following people contributed to the work:

$\begin{array}{ll}\text { Project Consultant } & \text { F. A. Schraub } \\ \text { Direction of Test Work } & \text { R. F. Boehm } \\ & \text { J. E. Hench } \\ & \text { E. E. Polomik } \\ & \text { B. B. Duncan } \\ \text { Test Setup } & \text { V. M. Horn }\end{array}$

Special Heater Rod Development

J. A. Kervinen

The help of these people, and others working under their direction, was essential to the successful completion of Task B, and is gratefully acknowledged.

The writer also wishes to express his thanks for the help provided by Messrs. D.S. Rowe of Battelle Northwest and R.W. Bowring of the U.K. Atomic Energy Establishment, Winfrith, in carrying out the COBRA and HAMBO code calculations, the results of which are listed in Tables 4 and 5.

\section{NOMENCLATURE}

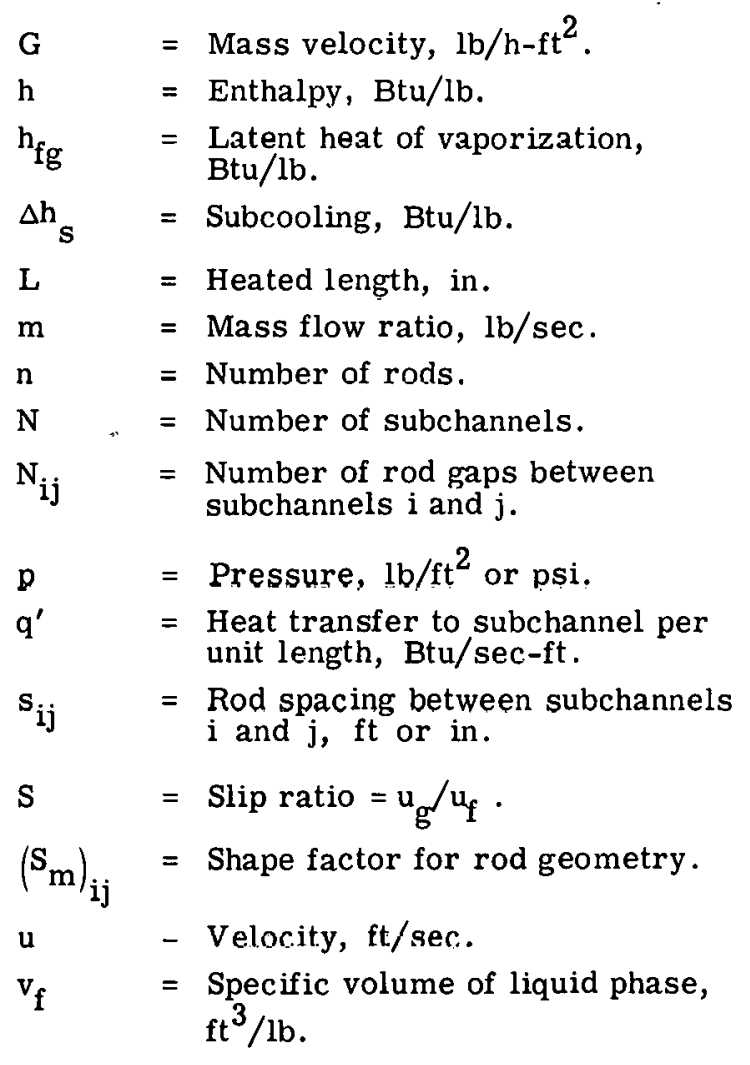




\section{NOMENCLATURE (Continued)}

\begin{tabular}{|c|c|c|}
\hline $\mathrm{v}_{\mathrm{g}}$ & $=$ & $\begin{array}{l}\text { Specific volume of vapor phase, } \\
\mathrm{ft}^{3} / \mathrm{lb} \text {. }\end{array}$ \\
\hline $\mathbf{v}$ & $=$ & $\begin{array}{l}\text { Specific volume of two-phase } \\
\text { mixture, } \mathrm{ft}^{3} / \mathrm{lb} \text {. }\end{array}$ \\
\hline $\mathrm{v}^{\prime}$ & $=$ & $\begin{array}{l}\text { Effective specific volume for } \\
\text { momentum considerations. }\end{array}$ \\
\hline$w_{i j}$ & $=$ & $\begin{array}{l}\text { Crossflow from subchannel i } \\
\text { to subchannel } j, \mathrm{lb} / \mathrm{sec}-\mathrm{ft} \text {. }\end{array}$ \\
\hline$w_{i j}{ }^{\prime}$ & $=$ & $\begin{array}{l}\text { Turbulent interchange between } \\
\text { subchannels i and } \mathrm{j} \text { (always } \\
\text { positive), lb/sec-ft. }\end{array}$ \\
\hline$w_{1 j}{ }^{\prime \prime}$ & $=$ & $\begin{array}{l}\text { Turbulent interchange between } \\
\text { subchannels i and } j \text {, un- } \\
\text { corrected for cross flow. }\end{array}$ \\
\hline $\mathbf{X}$ & $=$ & $\begin{array}{l}\text { Quality }=\text { mass rate of steam } \div \\
\text { total mass rate. }\end{array}$ \\
\hline$x_{c}$ & $=$ & Quality at CHF. \\
\hline $\mathbf{z}$ & $=$ & $\begin{array}{l}\text { Axial coordinate, positive in } \\
\text { direction of flow (Note: flow is } \\
\text { vertical and upward), ft or in. }\end{array}$ \\
\hline$\alpha$ & 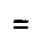 & Void fraction. \\
\hline$\beta$ & & $\begin{array}{l}\text { Turbulent mixing parameter } \\
\text { (COBRA). }\end{array}$ \\
\hline$\gamma_{i j}$ & & $\begin{array}{l}\text { m rod gap between } \\
\text { inels } i \text { and } j, \mathrm{ft} \text {. }\end{array}$ \\
\hline
\end{tabular}
$\eta \quad=$ Heated perimeter $\div$ total wetted perimeter.
$\eta_{1}, r_{2}=$ Factors in Becker's CHF cor- relation for multirod bundles, defined in text.
$\xi_{i} \quad=$ Ratio, heat flux on $i^{\text {th }}$ rod to maximum heat flux.
$\rho_{\mathrm{f}}=$ Density of liquid phase, $\mathrm{lb} / \mathrm{ft}^{3}$.
$\rho=$ Density of two-phase $=$ mixture, $\mathrm{lb} / \mathrm{ft}^{3}$.
$\phi \quad=$ Two-phase friction multiplier
$\bar{\phi}=$ Average heat flux, Btu $/ \mathrm{h}-\mathrm{ft}^{2}$.
$\phi_{\mathrm{c}} \quad=$ Critical heat flux, Btu $/ \mathrm{h}-\mathrm{ft}^{2}$.
$\phi_{1}=$ Hot corner rod heat flux, $\mathrm{Btu} / \mathrm{h}-\mathrm{ft}^{2}$.

\section{Subscripts}

i $=$ Refers to subchannel i.

$\mathrm{j}=$ Refers to subchannel $\mathrm{j}$, which is adjacent to and in communi- cation with subchannel i.

\section{REFERENCES}

1. Hench, J.E., and Boehm, R. F., "Nine-Rod Critical Heat Flux Investigation at 1000 psia," GEAP -4929, January 1966 .

2. Janssen, E., and Kervinen, J. A., "Two-Phase Pressure Drop in Straight Pipes and Channels; Water-Steam Mixtures at 600 to 1400 psia, "GEAP4616, May 1964.

3. Janssen, E., and Kervinen, J. A., "Burnout Conditions for Single Rod in Annular Geometry; Water at 600 to 1400 psia, "GEAP-3899, February 1963.

4. Barnett, P.G., "A Correlation of Burnout Data for Uniformly Heated
Annuli and its Use for Predicting Burnout in Uniformly Heated Rod Bundles, " AEEW-R463, Winf rith, England, September 1966.

5. Becker, K. M., "Measurements and Predictions of Burnout Conditions in Rod Bundles," Studsvik, Sweden, S-366, May 1967.

6. Matzner, B., "Comparison of Burnout Heat Fluxes in Wire Wrapped and Grid Spaced 19-Rod Bundles for the United Kingdom Steam Gencrating Heavy Water Reactor, " Columbia U. Engineering Research Laboratories Report NP-14831, December 1964. 


\section{REFERENCES (Continued)}

7. Edwards, P. A., and Obertelli, J.D., "Burnout and Pressure Drop Data on 37-Rod Clusters in High Pressure Water," AEEW-R488, 1966.

8. Matzner, B., and Casterline, J.E., "The Effect of Length and Pressure on the Critical Heat Flux for a Closely Spaced 19-Rod Bundle in Forced Convection Boiling," Columbia U. Engineering Research Laboratories Topical Report No. 7, Task XVI of Contract AT (30-3)-187, December 1965.

9. Becker, K.M., "A Burnout Correlation for Flow of Boiling Water in Vertical Rod Bundles, " AE-276, Studsvik, Sweden, 1967.

10. Rowe, D.S., "Cross Flow Mixing between Parallel Channels During Boiling, Part I : COBRA - Computer Program for Coolant Boiling in Rod Arrays," BNWL-371 PT 1, Battelle Northwest, March 1967.

11. St. Piere, C.C., "SASS Code I, Subchannel Analysis for the Steady State," APPE-41, Chalk River, Canada, September 1966 .

12. Bowring, R.W., "HAMBO, A Computer Programme for the Subchannel
Analysis of the Hydraulic and Burnout Characteristics of Rod Clusters, Part I : General Description, " AEEWR524, Winfrith, England, May 1967.

13. Armand, A.A., "The Resistance During the Movement of a Two"Phase System in Horizontal Pipes," Translated by V. Beak, AERE Trans. 828. Izvestiya Vsesojuznogo Teplotekhnicheskogo Instituta (1), pp. 16-23, 1946.

14. Martinelli, R.C., and Nelson, D. B., "Prediction of Pressure Drop During Forced Circulation Boiling of Water," Trans. ASME; V. 70, pp 695 - 702, August 1948.

15. Rowe, D.S., Private Communication, January 1967.

16. Moeck, E.O., Matzner, E., Casterline, J.E., and Yuill, G.K., "Critical Heat Fluxes in InternallyHeated Annuli of Large Diameter Cooled by Boiling Water at 1000 psia," International Heat Transfer Conference Paper 90, Chicago, August 1966.

17. Bowring, R.W., Private Communication, April 1967.

\section{DISTRIBUTION LIST}

\section{Copies}

Copies

Aerojet-General Corporation Nuclear Products and Services Group P.O. Box 77

San Ramon, California 94583

Attn: H. Jaffe

Argonne National Laboratory Reactor Engineering Division

9700 South Cass Avenue

Argonne, llinois 6043y

Attn: Dr. Paul Lottes

M. Petrick
Atomics International

P.O. Box 309

Canoga Park, California 91305

Attn: L. Bernath

Babcock \& Wilcox Company Atomic Energy Division. $\ddot{P} . \dot{0}$. Bóx 1260 Lynchburg, Virginia 24505

Attn: D. F. Judd 
Brookhaven National Laboratory Chemical Englneering Division Upton, New York 11973

Attn: Dr. O. E. Dwyer

Columbia University

Department of Chemical Engineering New York, New York 10027

Attn: J. Casterline

Combustion Engineering, Inc.

Nuclear Division

P.O. Box 500

Windsor, Connecticut 06095

Attn: Dr. P. Zmola

E. I. du Pont de Nemours and Co. Wilmington, Delaware 19898

Attn: J. S. Neill

Dynatech Corporation

17 Tudor Street

Cambridge, Massachusetts 02139

Attn: A. Bergles

General Electric Company

Atomic Power Equipment Department 2151 South First Street

San Jose, California 95103

Attn: Dr. S. Levy

Dr. F. Schraub

General Filectric Company

Research and Development Center

P. O. Box 8

Schenectady, New York 12301

Attn: Fred Staub

Knolls Atomic Power Laboratory

General Electric Company

P.O. Box 1072

Schencetady, New York 12301

Attn: Document Librarian

Geoscience Limited

8686 Dunaway Drive

La Jolla, Calıfornia 92037

Attn: H. Poppendiek

Massachusetts Institute of Technology Department of Mechanical Engineering Cambridge, Massachusetts 02139

Attn: Dr. W. Rohsenow Dr. P. Griffith

New York University

Department of Mechanical Engineering

University Heights

New York, New York 10453

Attn: Dr. Novak Zuber

North Carolina State University

Department of Chemical Engineering

Raleigh, North Carolina 27607

Attn: Dr. J. K. Ferrell
Oak Ridge National Laboratory

P.O. Box X

Oak Ridge, Tennessee 37830

Attn: H. W. Hoffman

Pacific Nor thwest Laboratory

P.O. Box $\theta 9 \theta$

Richland, Washington 99352

Attn: J. Batch

Rutgers, The State University College of Engineering

New Brunswick, New Jersey 08903

Attn: Dr. R. L. Peskin

Stanford University

Department of Mechanical Engineering

Stanford, California 94305

Attn: Dr. G. Leppert

TRW, Inc.

TRW Systems Group

One Space Park

Redondo Beach, California 90278

Attn: S. M. Zivi

University of Michigan

Department of Chemical and Metallurgical Engineering

Ann Arbor, Michigan 48103

Attn: R. Balzhiser

Westinghouse Electric Corporation Atomic Power Division

Box 355

Pittsburgh, Pennsylvania 15230

Attn: L. S. Tong

Westinghouse Electric Corporation Bettis Atomic Power Laboratory P. O. Box 79

West Mifflin, Pennsylvania 15122

Attn: S. Green

National Aeronautics \& Space Administration

Lewis Research Center

21000 Brookpark Road

Cleveland, Ohio 41135

Attn: R. Weltmann (SEPO) Librarian

A. Amorosi, Director

LMFBR Program Office

Argonne National Laboratory

9700 South Cass Avenue

Argonne, Illinois 60439

Atomic Finerey of C.anarla I_imited

Chalk River,

Ontario; Canada

Attn: G. A. Wikhammer 


\section{DISTRIBUTION LIST (Continued)}

U.S. Atomic Energy Commission Division of Reactor Development and Technology

Washington, D.C. 20545

Attn: R. M. Scroggins

N. Todreas

Water Projects Branch

Research \& Development $\mathrm{Br}$.

U.S. Atomic Energy Commission Division of Safety Standards

Washington, D.C. 20545

Attn: R. Impara

U.S. Atomic Energy Commission DTIE

P.O. Box 62

Oak Ridge, Tennessee

Centre d'Etudes Nucléaires

Chemin des Martyrs

Grenoble (Isere)

France

Attn: M. Mondin

CISE

Casella Postàle 3986

Milano (Segrate)

Italy

Attn: Prof. M. Silvestri

MAN

Abliolfach

Nürnberg 2

Germany

Attn: Dr. Mayinger

SNECMA

Division Atomique

22, Quai Gallieni

Suresnes (Seine)

France

Attn: M. Four'e

1

Technische Hogeschool Eindhoven

P.O. Box 313

Eindhoven

Netherlands

Attn: Prof. Dr. M. Bogaardt

AEG-Kernenergleversuchsaulàge 8752 GroBwelzheim (unterfranken)

Germany

Attn: Dr. Kirchenmayer

1

\section{CNEN}

Rome

Via Belisario, 15

Italy

Attn: M. Bianchi

Alsthom

38 Avenue Kléber

Paris $16 e$

France

Attn: M. P. Domenjoud

Centre d'Etudes Nucléaries de Saclay

B. P. $\mathrm{n}^{\circ} 2$

Gif-sur-Yvette (S\&O)

France

Attn: M. J. Horowitz

FIAT

Sezione Energia Nucleare

Via Settembrini 235

Torino

Italy

Attn: M. G. Cesoni

Reactor Centrum Nederland

112 Scheveningseweg

's Gravenhage

Netherlands

Attn: Prof. Dr. M. Bogaardt

ANSALDO

Direzione Generale

Piazza Carignano 2

Genova

Italy

Attn: Dr. E. Cristofori

EURATOM

Direction Générale R\& $\mathrm{E}$

51, rue Belliard

Bruxelles

Belgium

Attn: Dr. P. Kruys

\section{EURATOM}

Cásella Postale 1

Ispra (Varese)

Italy

Attn: M. $\bar{R}$. Morin 